This is the accepted version (pre-print) of the following article

Riina R, van Ee BW, Caruzo MBR, Carneiro-Torres DS, dos Santos RF, Berry

PE. 2021. The Neotropical Croton sect. Geiseleria (Euphorbiaceae):

Classification Update, Phylogenetic Framework, and Seven New Species from South America. Annals of the Missouri Botanical Garden 106: 111-166.

DOI: https://doi.org/10.3417/2021669

It has been published in final form at https://annals.mobot.org/index.php/annals/article/view/669

\title{
THE NEOTROPICAL CROTON SECTION GEISELERIA (EUPHORBIACEAE): CLASSIFICATION UPDATE, PHYLOGENETIC FRAMEWORK, AND SEVEN NEW SPECIES FROM SOUTH AMERICA ${ }^{1}$
}

\author{
Ricarda Riina ${ }^{2}$, Benjamin W. Van $\mathrm{Ee}^{3}$, Maria Beatriz Rossi Caruzo ${ }^{4,5}$, Daniela
} Santos Carneiro-Torres ${ }^{6}$, Rafaela Freitas dos Santos ${ }^{4}$, Paul E. Berry ${ }^{7}$

\section{ABSTRACT}

A revised assessment of Croton section Geiseleria is provided. The section as now circumscribed includes 84 species ranging across warm areas of the Americas. A nuclear ITS phylogeny of 150 accessions from 83 species and a chloroplast trnL-F phylogeny of 89 accessions from 65 species were generated to confirm correct phylogenetic placement of the species and to determine if any species previously included in the section should now be excluded. Seven new species are described, and we present a taxonomic synopsis that lists all currently accepted species along with their synonyms, distributions, and pertinent comments. We also recognize four subsections within $C$. sect. Geiseleria and list their corresponding species. Based on both morphological and molecular criteria, we now recognize $C$. lagunillae as a distinct species, rather than as a variety of $C$. guildingii (now treated as $C$. suavis), and we treat C. ramillatus var. magniglandulifer as a species, C. magniglandulifer. We also exclude $C$. tetradenius from $C$. sect. Geiseleria along with related species such as $C$. pulegiodorus and C. leptobotryus, which are either members of $C$. sect. Adenophylli or else may merit new sectional status. We also exclude $C$. waltherioides, although it is not clear to which section of Croton it belongs.

Key words: Amazonia, Andes, Caatinga, Cerrado, taxonomy.

${ }^{1}$ We thank Alfredo Fuentes (LPB), Manuel Luján (K), Viviana Londoño Lemos, and Santiago Madriñan (JBGP) for their help in locating and 
providing images of several specimens. Thanks also to Natanael Nascimentos dos Santos for providing the line drawings, Günter Gerlach for his photographs in Fig. 2, and Jacek Wajer for providing information about George Gardner's collections at BM and other herbaria. This work was supported in part by U.S. National Science Foundation award numbers DEB0212481 to PEB and DEB-1353070 to BVE and PEB. RR was supported by grant CGL2015-73621-JIN (AEI/FEDER).

${ }^{2}$ Real Jardín Botánico, RJB-CSIC, Plaza de Murillo 2, Madrid 28014, Spain.

${ }^{3}$ Department of Biology, University of Puerto Rico Mayagüez, Mayagüez, PR 00680, U.S.A.

${ }^{4}$ Universidade Federal de São Paulo, Departamento de Ecologia e Biologia Evolutiva, Rua Prof. Artur Riedel, 275, Jd. Eldorado, CEP 09972-270, Diadema, SP, Brazil.

${ }^{5}$ Instituto de Botânica, Secretaria do Meio Ambiente, Cx. Postal 68041, 04045-972, São Paulo, SP, Brazil.

${ }^{6}$ Universidade Estadual de Feira de Santana, Pós Graduação em Botânica, Av. Transnordestina s/n, Novo Horizonte, CEP 44036-900, Feira de Santana, Bahia, Brazil.

${ }^{7}$ University of Michigan Herbarium and Department of Ecology and Evolutionary Biology, 3600 Varsity Drive, Ann Arbor, MI 48108-2287, U.S.A. 
Croton L. section Geiseleria (A. Gray) Baill., in its current circumscription, now includes 84 species of herbs and shrubs distributed across the Americas (Fig. 1). This number takes into account the species listed in Van Ee et al. (2011), the recent revision of Brazilian species by Sodré et al. (2019a), and the revised synopsis contained herein, including the seven new species described below. Although there is not any single, obvious morphological synapomorphy that unites the section, most species of $C$. sect. Geiseleria share a suite of characters that distinguish them from other sections within Croton. These characters include stellate pubescence, usually dentate or crenate leaves with a pair (or more) of usually stipitate nectary glands at the apex of the petiole, nectary glands often in the sinuses of the leaf margins, pistillate flowers with unequal sepals in many species, and bisexual inflorescences with unisexual cymules (Van Ee et al. 2011). In many species both the acropetiolar glands and the marginal glands (if present) are trumpetshaped (flaring open wider towards the apex), though the length of the stalk and the size of the secretory area at the apex of the glands vary considerably (Fig. 2A). To these formerly reported characters we can now add two more, namely the presence of persistent, often upcurved bracts subtending the staminate cymules (Figs. 2C \& D), and a particular kind of receptacular cup (formed by the fused bases of the sepals) that remains after the capsule dehisces (Figs. 2E \& F).

Croton sect. Geiseleria is widespread in warm regions of the New World, with its greatest diversity in Brazil, followed by Mexico (Van Ee et al. 2011; Sodré et al. 2019a; see Fig. 1). Members of the section typically grow in open and dry areas, such as along roadsides, edges of pastures, white sand areas, or rocky outcrops, from sea level to around $2150 \mathrm{~m}$ elevation. Croton glandulosus L. is a common weed in cotton and peanut fields in the southern United States (Askew \& Wilcut 2001). Croton glandulosus and C. hirtus L'Hér. have also become established in parts of the Old World tropics (Radcliffe-Smith 1978, Preetha \& Binojkumar 2006, Wang et al. 2012). Taxonomic and floristic studies covering species of $C$. sect. Geiseleria published within the last decade include Secco (2009), Carneiro-Torres et al. (2011), Secco et al. (2012), Silva et al. (2014), Sodré \& Silva (2017), and Sodré et al. (2017, 2019a, 2019b), but considerable work still needs to be done to complete species inventories, understand species distribution ranges and relationships, and better resolve the evolutionary history of the group.

While working on several Neotropical lineages of Croton (Caruzo \& Cordeiro 2013, Feio et al. 2018a, Riina et al. 2018), regional floras (CarneiroTorres 2009, Santos et al. 2017), and the Flora do Brasil 2020 project (Cordeiro et al. 2015; Silva et al. 2020), we discovered a number of specimens that clearly belong to Croton sect. Geiseleria but were unassignable to any known species in the group. As a result, we propose here seven new species in the section. These are distributed in southeastern Brazil (C. almadinensis Caruzo \& Riina, C. kallunkiae Riina \& Caruzo, and C. pluriglandulosus Carn.-Torres \& Riina), the Amazon basin (C. amaraliae Riina \& P. E. Berry), mid-elevation montane forest in Peru (C. huamaliensis Riina) and Colombia (C. cuadrosii P. E. Berry), and high-elevation dry forest in Bolivia ( $C$. curculiospermus Riina). We describe and illustrate the new taxa and compare them with morphologically similar species in the section. We also report and analyze nuclear ITS and chloroplast $t r n L-F$ sequences for the new taxa and 
other species of interest to assess their placement in the section. Finally, we provide an updated synopsis of all the species in $C$. sect. Geiseleria, including the recognition of four subsections, a key to the subsections, and lists of their component species.

\section{MATERIALS AND METHODS}

This study was based on the analysis of collections deposited in the following herbaria: A, ALCB, AMES, ASE, EAC, CEPEC, DAV, F, G, GH, HUEFS, HRCB, HUVA, IPA, INPA, JBGP, K, LE, LPB, MA, MAPR, MBML, MICH, MO, MOSS, NY, P, PEUFR, RB, RSA, SP, SPF, UESC, US, USZ, VEN, VIES, W, and WIS (acronyms follow Thiers 2020, continuously updated). Type collections and protologues of related taxa were also studied for a better understanding of morphological affinities of the new species. Morphological terms used in descriptions follow Stearn (1992), Webster et al. (1996), Vitarelli et al. (2015), and Feio et al. (2016, 2018b).

Information about habit, habitat, and distribution was taken from specimen labels and our own field observations. The new species distribution map was made using the software QGIS 2.10.1 (QGIS Development Team 2015). Geographic coordinates used for mapping were obtained from herbaria material or electronic gazetteers. Online platforms of specimen data such as speciesLink (http://splink.org.br) and the Reflora virtual herbarium (http://reflora.jbrj.gov.br) were also used to locate herbarium specimens. Preliminary species conservation categories were proposed using the IUCN Red List guidelines (IUCN 2012).

For the molecular analyses, our primary reason for analyzing molecular data for specimens of Croton sect. Geiseleria was to corroborate the placement of species within the section and to aid in verifying specimen identification to species. Although the phylogenetic analyses were not intended to be a thorough test of the monophyly of the section, a representation of the sections most closely related to $C$. sect. Geiseleria from the analyses of Van Ee et al. (2011) was used along with more distantly related species of Croton, with Astraea surinamensis (Miq.) O. L. M. Silva \& Cordeiro and Brasiliocroton mamoninha P. E. Berry \& I. Cordeiro serving as outgroups. The nuclear ribosomal internal transcribed spacer (ITS1, 5.8S, and ITS2) and the chloroplast trnL-F (trnL exon, intron, and 3 ' intergenic spacer) have been widely employed in Croton molecular phylogenetic studies starting with Berry et al. (2005), and they have proven to be useful for determining specimens to species in other sections (e.g., Van Ee \& Berry 2010, Caruzo et al. 2011). We therefore assembled all of the published ITS and trnL-F sequences of taxa ascribed to $C$. sect. Geiseleria and then generated new sequences for additional taxa suspected of belonging to the section (Appendix).

DNA extraction, PCR amplification, and sequencing were performed at laboratories in Brazil (Universidade Estadual de Feira de Santana), Spain (Real Jardín Botánico de Madrid), and the United States (University of Michigan). Laboratory methods largely followed those of Berry et al. (2005). For most specimens, the combined ITS1, 5.8S, and ITS2 region was amplified with primers ITS-I (also known as "Leu1") and ITS4 (White et al. 1990, Urbatsch et al. 2000), and samples that initially failed to amplify with these 
primers were amplified with the primer combinations ITS-I with ITS2, and ITS3 with ITS4 (White et al. 1990). The chloroplast $t r n L-F$ region was amplified and sequenced with primers "C" and "F," and samples that initially failed were amplified and sequenced in two pieces with " $C$ " paired with " $D$ " and "E" paired with "F" (Taberlet et al. 1991). See Van Ee et al. (2011) for a detailed list and sequences of all the primers used here. Chromatograms were edited and assembled in Sequencher v. 5.2.4 (Gene Codes Corporation, Ann Arbor, MI, USA), and aligned in SeaView v. 4.7 (Gouy et al. 2010) with subsequent manual adjustment. The aligned matrices were analyzed using AIC in MrModeltest v. 2.3 (Nylander 2004) to determine the best-fitting model. The matrices were analyzed separately with Bayesian inference (BI) in MrBayes ver. 3.2.3 (Ronquist et al. 2012) on the XSEDE-CIPRES platform (Miller et al. 2010), setting the parameters that can be set according to the best-fitting model. Bayesian posterior probabilities (PP) were obtained from two runs of four chains each with the following settings: heating parameter = $0.2,100,000,000$ generations, starting from random trees, default priors, sampling every 5,000 generations, and discarding the first $30 \%$ of the sampled trees as the burn-in.

\section{RESULTS AND DISCUSSION}

\section{Molecular analysis}

A total of 81 newly generated and 69 previously published ITS sequences and 43 newly generated and 46 published trnL-F sequences were analyzed, with all newly generated sequences deposited in GenBank (Appendix). The ITS and trnL-F Nexus files were submitted to TreeBASE (accession \# 27234). An examination of the Potential Scale Reduction Factor convergence diagnostic values (PSRF; Gelman and Rubin 1992) of the 12 measured parameters suggested that convergence had been reached in the Bayesian analyses. The majority-rule consensus of the post-burn-in trees was computed for each of the two markers (Figs. $3 \& 4$ ). The branches with 0.95 or greater Posterior Probability values are indicated on the figures by thicker lines.

The earlier and more limited phylogenetic analyses by Berry et al. (2005) and Van Ee et al. (2011) did not recover $C$. sect. Geiseleria as a monophyletic group due to the placement of $C$. trinitatis Millsp. outside of the rest of the section. The chloroplast $\operatorname{trn} L-F$ analyses of Berry et al. (2005) and Van Ee et al. (2011) also recovered $C$. trinitatis in an unsupported position separate from the rest of the sampled members of the section. The EMB2769 exon 9 (nuclear) and rps3 (mitochondrial) analyses of Van Ee et al. (2011) recovered it in yet other positions, suggesting that it is a more complex issue than just incongruence between nuclear and chloroplast data. The ITS analyses of Berry et al. (2005), Van Ee et al. (2011), and the ITS and trnL-F analyses presented here (Figs. $3 \& 4$ ), together with morphological data, strongly suggest that $C$. trinitatis is indeed a good member of $C$. sect. Geiseleria, and that the section is monophyletic. We believe that the greatly increased sampling of species that now emerge close to C. trinitatis (Clades B and C), and which were lacking in earlier studies by Berry et al. (2005) and Van Ee et al. (2011), has contributed towards increased support for recovering $C$. trinitatis within the section. Nonetheless, $C$. trinitatis would be an excellent 
candidate for investigating genomic rearrangements or an accelerated rate of evolution relative to closely related species, particularly as these might relate to its success as a weedy species.

Both the ITS (Fig. 3) and trnL-F (Fig. 4) analyses recover Croton sect. Geiseleria as a strongly supported monophyletic group. Within $C$. sect. Geiseleria, there are four major clades that can be recognized in the ITS phylogeny (Fig. 3). The same clades are resolved in the $t r n L-F$ phylogeny (Fig. 4), with the exception of Clade $\mathrm{C}$, since $C$. trinitatis is recovered separately there. Clade A includes a large assemblage of species covering the entire geographic range of the section. There are two main subclades, with the smaller subclade including five of the newly described species in this paper. The other subclade includes the weedy $C$. glandulosus, sister to a group of three endemic Mexican species (C. cupulifer McVaugh, C. martinianus V. W. Steinm., and $C$. varelae V. W. Steinm.), and then the similarly weedy $C$. hirtus sister to the remaining accessions. The remainder of the subclade, shown at the top of the phylogram in Figure 3, has four South American species $(C$. goyazensis Müll. Arg., C. hostmannii Miq., C. macrosepalus Sodré \& M. J. Silva, and C. parodianus Croizat) in a grade along with the two Brazilian accessions Sant'Ana 1106 and Sant 'Ana 1131, which are discussed below as possible hybrids of $C$. glandulosus and another unknown species. Beyond that, the numerous remaining accessions in the subclade are all from Mexico, Central America, northern South America, and the Caribbean, including the $C$. suavis complex discussed further below.

The smaller Clade B consists of the widespread C. nepetifolius Baill., from Brazil, Bolivia, and Peru, which is sister to C. campinarensis Secco, A. Rosario \& P. E. Berry, which are in turn sister to C. agoensis Baill. and $C$. mucronifolius Müll. Arg., both Brazilian cerrado species. Clade $\mathrm{C}$ is a largely South American group, with a grade consisting of the widespread C. trinitatis, followed by the Brazilian C. lundianus (Didr.) Müll. Arg. and the closely related $C$. aberrans Müll. Arg., then a larger subclade with species from Brazil, northern South America, Peru, and two from Mexico and Central America (C. brevipes Pax and C. macrodontus Müll. Arg.). Finally, Clade D, which is sister to the other three, but with weak support, includes a mixture of Mexican and Caribbean species (C. betulinus Vahl, C. malvavisciifolius Millsp., C. repens Schltdl., and C. mcvaughii G. L. Webster) in two sister subclades. Sister to those is a subclade consisting of the widespread South American C. antisyphiliticus Mart., and finally, sister to the rest is a clade of entirely Brazilian species, including $C$. asperrimus Benth., C. glechomifolius Müll. Arg., C. triangularis Müll. Arg., and C. verbenifolius Müll. Arg.

ITS sequences were analyzed for 56 of the 84 species that we recognize for Croton sect. Geiseleria, representing a sampling of approximately $60 \%$ of the section. Of these 56 species, 27 are represented by a single accession, and therefore the monophyly of these species is not being tested here. Of the 29 species for which more than one accession is included, 20 are recovered as monophyletic and nine are recovered as nonmonophyletic. Among the nine that are recovered as non-monophyletic, the newly described $C$. kallunkiae is rendered paraphyletic by $C$. arenosus Carn.Torres \& Cordeiro, and C. grewioides Baill. is rendered paraphyletic by the newly described C. curculiospermus (Fig. 3). Six of the non-monophyletic species are in the 'Croton suavis complex,' named after the earliest accepted 
name in the group (Figs. $3 \& 4$ ). In the ITS tree (Fig. 3), the five accessions of C. flavoglandulosus Lundell are arranged as a grade at the base of the complex. A hypothesis that might explain this is that the accessions from Belize (Brokaw 183 and 334) may represent genetic introgression between more inland and western populations of $C$. flavoglandulosus and the northern Yucatán Peninsula populations of $C$. itzaeus Lundell. Although these specimens are morphologically assignable to C. flavoglandulosus, more data, particularly chloroplast marker sequences, are needed to further explore this issue. All accessions of $C$. jutiapensis Croizat, $C$. lagunillae Croizat, $C$. ortholobus Müll. Arg., C. ramillatus Croizat, and C. suavis Kunth, Bonpland $\&$ Humboldt were recovered within a clade in the $C$. suavis complex with very little resolution among them (Fig. 3). Among these five species, there are a total of 13 synonymous names, many recognized as synonyms here for the first time. This indicates how geographically widespread and morphologically variable this complex is. Although the ITS data do not recover each of these five species as reciprocally monophyletic, our decisions on which species to recognize is based on morphological and ecological distinctions, and this results in each taxon being largely allopatric with regards to the rest.

There are over 30 infraspecific taxa that have been described within $C$. glandulosus (Govaerts et al. 2000). In the treatment of the taxon for the Flora of North America North of Mexico, Van Ee et al. (2009) and Van Ee \& Berry (2016) accepted five varieties of C. glandulosus, but taxa from the Caribbean, Mexico, Central America, and South America have not been closely studied yet. Figures $3 \& 4$ show a small clade that is sister to $C$. glandulosus, consisting of three species that are endemic to Mexico (C. cupulifer, $C$. martinianus, and $C$. varelae) that are morphologically similar to $C$. glandulosus. These should all be critically re-examined as part of a more comprehensive study of the entire range of C. glandulosus.

We had orignally identified the specimens Sant'Ana 1106 and 1131 from Bahia, Brazil as C. glandulosus, but the ITS results presented here (Fig. 3 ) do not recover them together with the other accessions determined as $C$. glandulosus. Instead, they are recovered with strong support sister to $C$. hostmannii, C. parodianus, and C. mollis (Fig. 3). A re-examination of these specimens does not reveal any morphological reasons why these would not be C. glandulosus. A closer examination of the ITS matrix does not reveal any misaligned or other obvious problem. Maximum Parsimony analyses of the ITS1 portion of the data (results not shown) recovered Sant'Ana 1106 and 1131 in the same position as the Bayesian analyses of the entire portion of ITS (Fig. 3). In contrast, Maximum Parsimony analyses of just ITS2 recover them sister to $C$. glandulosus $+C$. cupulifer, $C$. martinianus, and $C$. varelae. The chloroplast marker trnL-F (Fig. 4) recovers Sant'Ana 1106 and 1131 together with $C$. glandulosus var. glabratus from Puerto Rico, and separate from $C$. hostmannii, C. mollis, and the North America accessions of C. glandulosus. In light of this incongruence, we hypothesize that the Sant'Ana 1106 and 1131 specimens represent hybrids between a $C$. glandulosus maternal parent and another probably unsampled species as the paternal parent, possibly along with subsequent genetic introgression. The Sant'Ana 1106 specimen is morphologically very consistent with C. glandulosus, whereas the Sant'Ana 1131 specimen has leaves with a slightly thicker appearance, denser indumentum, and coarser marginal teeth. 
The role of hybridization in the evolutionary history of Croton remains largely unexplored. Van Ee et al. (2008) hypothesized that the Puerto Rican endemic $C$. poecilanthus Urb. is the result of an ancient hybridization between a member of the Cuban C. sect. Moacroton (Croizat) B. W. van Ee \& P. E. Berry and a distantly related South America taxon. Riina et al. (2009) also hypothesized that $C$. sect. Cyclostigma Griseb. could be the product of an ancient hybridization, given its contrasting phylogenetic placement between nuclear and chloroplast data. Kainulainen et al. (2016) reported field observations of hybridizations between the closely related C. plurispicatus P.E. Berry, Kainul. \& B.W. van Ee and C. submetallicus Baill. in Madagascar. Based on alkaloid contents, Stuart and Woo-Ming (1969) concluded that $C$. vaillantii Geiseler (as $C$. plumieri Urb.) was a hybrid between the closely related yet readily differentiated $C$. linearis Jacq. and $C$. flavens $\mathrm{L}$. We add to these the observation of potential hybridization events within $C$. sect. Geiseleria between the closely related C. flavoglandulosus and C. itzaeus, and between $C$. glandulosus and an unknown, but presumably close relative.

Van Ee (2006) and Van Ee et al. (2011) placed C. santaritensis Huft in $C$. sect. Geiseleria with some uncertainty, based on the analyses of an ITS sequence obtained from an isotype of the species (Knapp 5882, DAV) which recovered it within $C$. sect. Geiseleria, even though it is not a good morphological match to the section. In the protologue of $C$. santaritensis, Webster \& Huft (1988) indicated that no close relative of the species was known, and no closely resembling species had been located at F or MO, which also contributed to the decision to tentatively assign it to $C$. sect. Geiseleria. A subsequent examination of the ITS sequence originally deposited as $C$. santaritensis (EU478090.1) reveals that the ITS1 portion of DNA amplified with primers Leu1 and ITS2 corresponds to $C$. sect. Cleodora, and the ITS2 portion amplified with primers ITS3 and ITS4 corresponds to $C$. sect.

Geiseleria. An examination of the original lab notebook (PCR clean-up; 22 March 2006; B. Van Ee) revealed a note in the margin of the sheet in which ITS3-ITS4 PCR products were cleaned stating that "some tubes spilled and there is a possibility that they got back in the wrong place." A thorough examination of the ITS sequences ultimately generated from that work revealed that most likely the tubes corresponding to Knapp 5882 and Torres 418 (C. ramillatus) had been switched. We have provided corrected ITS sequences for these (EU478090.2 and EU478082.2; Appendix) and generated new ITS and $t r n L-F$ sequences from another collection of $C$. santaritensis (Lee 8075). Croton santaritensis is a good morphological match for $C$. sect. Cleodora, where it was treated by Riina et al. (2018), and where the most recent phylogenetic analysis of $C$. sect. Cleodora has placed it (Masa-Iranzo et al. 2021), as well as our own molecular results (Figs. $3 \& 4$ ).

In a paper describing Croton macrosepalus, Sodré et al. (2019b) generated and analyzed ITS and trnL-F sequences of $C$. macrosepalus and $C$. spica Baill. We downloaded these sequences from GenBank and included them in our analyses. The ITS sequences were difficult to align with the rest of the $C$. sect. Geiseleria ITS matrix, and they are each recovered at the end of an unusually long branch within Clade A (Fig. 3). The most similar sequence to C. macrosepalus is $8 \%$ different, and the one most similar to C. spica is $14 \%$ different. By comparison, the ITS sequences of C. betulinus and C. ramillatus, which are about as distantly related as any taxa within $C$. sect. Geiseleria (Fig. 
3), are approximately 12\% different. Although Sodré et al. (2019b) used different primers (17SE and 26SE; Sun et al. 1994) to amplify ITS compared to those used here and in previous molecular studies in Croton, this should not affect the quality of the resulting sequences. One possibility is that these sequences were heavily edited, perhaps due to poor quality, which introduced artifacts, but we will need new independent ITS sequence data to verify this. We performed the same phylogenetic analysis of ITS with these two sequences excluded (not shown), and the resulting topology was the same.

Unlike the ITS sequences, the trnL-F sequences of $C$. macrosepalus and $C$. spica generated by Sodré et al. (2019b) were not difficult to align. Our analysis recovered the two species sister to each other within a polytomy at the base of Clade A of $C$. sect. Geiseleria (Fig. 4). These two sequences share unique variations within the "D" and "E" primer portion (Taberlet et al. 1991) and at their ends that are not found in any other species of $C$. sect. Geiseleria, which suggests to us that they may be the result of errors in the chromatogram editing step. Sodré et al. (2019b) reported using primers "C" and "D" (Taberlet et al. 1991) to generate these sequences, but they most likely used the combinations of primers "C" with " $D$ " and "E" with " $F$ " given that these sequences extend from primer " $C$ " to primer " $F$." We also performed the same phylogenetic analysis of trnL-F with these two sequences excluded, and the resulting topology was the same as in Figure 4. Although Sodré et al. (2019b) compared C. macrosepalus and C. spica to each other and even hypothesized that they are closely related, in their broader treatment of the section in Brazil (Sodré et al. 2019a) they did not consider them particularly closely related or morphologically similar. Given their morphology, we conclude that $C$. macrosepalus and $C$. spica are both members of $C$. sect. Geiseleria, that they likely belong to Clade A ( $C$. subsect. Geiseleria), but that they are not necessarily closely related.

Croton tetradenius Baill., C. leptobotrys Müll. Arg., and $C$. pulegiodorus Baill. were first included in $C$. sect. Geiseleria, based only on morphological characters, by Van Ee et al. (2011), and this was followed by Sodré et al. (2019a), although the latter treated $C$. pulegiodorus and $C$. leptobotrys as synonyms of $C$. tetradenius. However, our phylogenetic results show that these clearly do not belong in $C$. sect. Geiseleria, since the accessions we sequenced form a highly supported clade related to $C$. sect. Adenophylli Griseb. (Figs. $3 \& 4$ ). A re-examination of $C$. tetradenius, $C$. leptobotrys, and C. pulegiodorus revealed previously overlooked morphological features that do not align them closely with $C$. sect. Geiseleria, so our molecular results are also supported by morphological data. A few specimens of $C$. tetradenius also show dehisced capsules with intact columellas, and there the columella appears to have the same kind of smooth, 3-lobed apex as found throughout $C$. sect. Adenophylli, but this character needs to be better evaluated with more fruiting specimens or in fresh material in all three taxa.

New Species in Croton sect. Geiseleria

Croton almadinensis Caruzo \& Riina, sp. nov. TYPE: Brazil. Bahia: Serra do Corcovado, $9.8 \mathrm{~km}$ a SW de Coarci na estrada para Almadina, dai $\mathrm{N}$ ate Fazenda São Jose, 14 42’21”S, 39 36'12”W, 650-750 m, 21 Jun. 2005, $P$. 
Fiaschi, J. Paixão, L. C. Gomes, S. Sant'Ana et al. 2922 (holotype, CEPEC!; isotypes, MICH!, NY!). Figure 5.

Diagnosis. Croton almadinensis is morphologically similar to $C$. sincorensis Mart. ex. Müll. Arg. in its (narrowly) ovate to elliptic-oblong leaves with irregularly serrate margins, stipitate nectary glands in each sinus of the leaf margins, and long-stipitate acropetiolar glands, but $C$. almadinensis can be distinguished by its membranaceous leaves with slender marginal glands (vs. coriaceous leaves with more robust marginal glands in $C$. sincorensis), inflorescences with flowers continuously spaced along the rachis (vs. inflorescences with a gap between the proximal pistillate flowers and distal staminate flowers in C. sincorensis), and pistillate flowers with petals reduced to small glands and bifid styles (vs. oblong pistillate petals and multifid styles in C. sincorensis).

Shrubs $0.5-2 \mathrm{~m}$ tall, monoecious; young branches with sparse, slightly stipitate stellate trichomes, usually porrect, vinaceous, ochraceus or reddish; latex not reported. Leaves narrowly ovate to elliptical-oblong, 6-12 x 3-4.5 $\mathrm{cm}$, membranaceous, slightly discolorous, apex acute to long-acuminate, base obtuse to rounded, margin irregularly serrate (rarely subentire), with stipitate nectary glands usually present in the sinuses, colleters (not nectariferous glands) scattered along the margin; both marginal nectaries and colleters often caducous on mature leaves; venation pinnate, brochidodromous, 5-7 pairs of secondary veins; adaxial leaf surface glabrous or sparsely stellate-porrect, abaxial surface sparsely stellate-porrect; petioles $0.5-1.2(-2) \mathrm{cm}$, stipitate appressed- or porrect-stellate, with 2 or occasionally 3 or 4 slender, longstipitate nectary glands at junction with blade, stipe $1-2(-3) \mathrm{mm}$; stipules linear to lanceolate, $1.5-3 \mathrm{~mm}$, caducous. Inflorescences terminal, rarely axillary, 2.5-7 cm, erect, rachis with stipitate appressed stellate trichomes, proximal cymules pistillate, 1-flowered, distal cymules staminate, 1(-3)flowered, without noticeable gap between pistillate and staminate flowers; bracts triangular to lanceolate, $1-5 \mathrm{~mm}$ long, upcurving, ending with tuft of trichomes. Staminate flowers with thin pedicel 2-3 mm; sepals 5, valvate, ovate, ca. $1.5 \times 0.9 \mathrm{~mm}$, apex acute, glabrous on inner surface, sparsely stellate-porrect on outer surface; petals 5, elliptic, 2-2.5 $\mathrm{mm}$ x $0.8-1 \mathrm{~mm}$, densely villous-lanate on inner surface, sparsely villous on outer surface; receptacle villous-lanate; stamens $10,2-3 \mathrm{~mm}$, anthers $0.2-0.3 \times 0.2-0.3 \mathrm{~mm}$. Pistillate flowers with pedicels (2-)4-5 mm; sepals 5(6), strongly to slightly unequal, narrowly oblong to spathulate, 3-4(-6) x 0.6-2 $\mathrm{mm}$, well separated from each other at anthesis, apex acute to obtuse, glabrous on inner surface, sparsely stellate-hispid to glabrate on outer surface; petals reduced to small gland (colleter); ovary spheroid, sparsely stellate-porrect; styles bifid from base, with 6 terminal branches, sparsely stellate. Capsules spheroid, 5.5-6 mm diam., sparsely stellate, columella persistent. Seeds spheroid-oblongoid, 4-4.5 x 3.8-4 mm, surface smooth, dark brown; caruncle transversely oblong, ca. $0.3 \times 0.6 \mathrm{~mm}$.

Distribution and habitat. This species is only known from southern Bahia state, Brazil, where it grows in submontane to montane moist forest at 650-900 m elevation (Fig. 6). 
Phenology. Croton almadinensis has been collected with flowers in January, June, and September to November, and with fruits in June, September, and October.

Etymology. This species is named after the municipality of Almadina, in Bahia state, where the type and most of the known specimens have been collected.

Preliminary IUCN Red List category. Croton almadinensis is known from only two localities (Almadina and Eunápolis), neither of which is under any official protection status. Because it has been collected in fewer than ten localities, with a small geographic range, we think it might be categorized as Vulnerable (VU) under a more rigorous analysis.

Notes. This species can be recognized by its narrowly ovate to ellipticleaves with long-stipitate, trumpet-shaped nectary glands along the margin and at the petiole apex, as well as glabrate to sparsely stellate-porrect blades, the presence of reddish stellate trichomes on young branches and petioles, and 13 pistillate flowers at the base of the inflorescence. Herbarium specimens of $C$. almadinensis have been previously misidentified as $C$. sincorensis, mainly due to similarities in vegetative morphology, but they can be separated by the characters given in the diagnosis above.

Croton almadinensis is also morphologically similar to C. brevipes, a species occurring in northern Colombia, Central America, and Mexico. The former differs by its eglandular stipules, smaller leaves with a pair of long and delicate petiolar nectary glands, and bifid styles (vs. glandular stipules, larger leaves usually with a pair of robust petiolar nectary glands, and tetrafid styles in $C$. brevipes). Both $C$. brevipes and $C$. sincorensis also differ in having a gap in the inflorescence between the pistillate and staminate flowers, which is consistent with their placement distant from $C$. almadinensis in the ITS and trnL-F phylogenies (Figs. $3 \& 4$ ).

One of the cited specimens, Fiaschi et al. 2771, differs from the rest of the specimens assigned to $C$. almadinensis by its nearly entire leaf margins and much shorter pistillate pedicels, but it is tentatively included here under this species.

Paratypes. BRAZIL. Bahia: Almadina, Serra do Corcovado, 13.8 km ao SW de Coaraci, estrada para Almadina, Fazenda São José, 14²'’21'S, 39³6' 'W, 650-900 m, 22 Nov. 2005, M. M. M. Lopes, S. Sant'Ana, L. C. de J. Gomes, A. B. Rodrigues 372 (CEPEC, MA, MICH, NY); ibid., 30 Jan. 2005, A. Amorim, F. Matos, J. Paixao, S. Sant'Ana \& B. Rodrigues 4704 (CEPEC, NY); ibid., 650-750 m, 19 Sep. 2004, W. W. Thomas, A. M. Amorim, P. Fiaschi, J. L. Paixao, S. Sant'Ana 14194 (CEPEC, NY); ibid., 27 Sep. 2005, L. A. Mattos-Silva, J. L. Paixao, S. de Sant'Ana, B. Santos \& L. Gomes 4904 (HUESC); ibid., $14^{\circ} 43^{\prime}$ 'S, 39³6'W, 2 Oct. 2003, P. Fiaschi, A. M. Amorim, S. C. Sant'Ana \& J. L. Paixao 1625 (CEPEC, MICH); ibid., 17 Dec. 2006, R. A. X. Borges, A. M. Amorim, J. L. Paixão \& A. B. Rodrigues 442 (CEPEC); Almadina, Serra do Corcovado, acesso pela Fazenda São José, Proprietário Senhor Francisco, floresta ombrófila densa montana, 831 m, 3 Sep. 2011, M. 
M. Coelho 377 (CEPEC, UESC); ibid., 12 Aug. 2007, D. Cardoso 2128

(CEPEC, HUEFS); Almadina, Rodovia de Almadina para Ibitupã, ca. 20 km, Fazenda São Roque, ca. $10 \mathrm{~km}$ da estrada do ramal, 14 $38^{\circ} 27^{\prime}$ 'S, 3942'47' 'W, 12 Mar. 2005, P. Fiaschi, J. L. Paixao, L. C. J. Gomes \& A. B. Rodrigues 2771 (CEPEC, MA, MICH); Eunápolis, saída de Eunápolis a Itamaraju, BR 101, $40 \mathrm{~km}$ de Itamaraju, Mata, 16 Sep. 1968, J. Almeida \& T. S. Santos 41 (CEPEC, DAV).

Croton amaraliae Riina \& P. E. Berry, sp. nov. TYPE: Brazil. Pará: Itaituba, estrada Santarém-Cuiabá BR 163, km 171, próximo a divisão Pará-MT, 9³5'S, 54³5'W, 22 Apr. 1983, I. L. Amaral, N. Silva, O. P. Monteiro, J. Lima, L. Brako, W. D. Reese \& M. Dibben 872 (holotype, INPA 112263!; isotypes, MO 3296892!, NY!, US 3336275!). Figure 7.

Diagnosis. Croton amaraliae is similar to C. parodianus in its ovate to broadly lanceolate leaves with a cordate base and crenate to serrate margins with stipitate nectary glands in the sinuses, but differs in its smaller leaves $(3.5-5.5(-8) \times 1.2-2(3.5) \mathrm{cm}$ vs. $5.2-15 \times 3.1-8.5 \mathrm{~cm}$ in $C$. parodianus) with shorter petioles (8-16 mm vs. $17-75 \mathrm{~mm}$ vs. in C. parodianus) and smaller capsules (3.5 x 3-3.2 mm vs. 4.6-4.9 x 4.7-6.4 mm in C. parodianus).

Shrubs up to $2 \mathrm{~m}$ tall, monoecious; young branches with a dense indumentum of pale, appressed, stellate-porrect trichomes; latex not reported. Leaves ovate to broadly lanceolate, $3.5-5.5(-8) \times 1.2-2(-3.5) \mathrm{cm}$, membranaceous, discolorous, apex acute, base cordate or rarely rounded, margin crenate to crenate-dentate, with stipitate cupuliform nectary glands in the sinuses, colleters (not nectariferous glands) scattered along the margin alternating with nectaries; both marginal nectaries and colleters occasionally falling off from mature leaves; venation pinnate, brochidodromous, with 5 pairs of secondary veins, leaf adaxial surface sparsely stellate, abaxial surface densely stipitate-stellate; petioles $0.8-1.6 \mathrm{~cm}$, stellate, with 2(4) shortly stipitate nectary glands at apex; stipules linear, $1.5-3 \mathrm{~mm}$, caducous. Inflorescences terminal, $2.5-7 \mathrm{~cm}$, erect, rachis stellate, proximal pistillate cymules 1-flowered, distal staminate cymules 1-flowered, without a gap between the two sections; bracts narrowly triangular to linear, $2-3 \mathrm{~mm}$, stellate. Staminate flowers with short pedicels 1-2 mm; sepals 5, valvate, ovate, 1.5-2.5 x 1-1.5 mm, apex acute, villous on inner surface, stellatetomentose to stellate-villous on outer surface; petals 5, elliptic to oblongelliptic, $2-2.5 \times 0.5-1 \mathrm{~mm}$, densely villous on inner surface, villous on outer surface; receptacle villous; stamens ca. 11, anthers $0.3-0.4$ x $0.2-0.3 \mathrm{~mm}$. Pistillate flowers with short pedicels 1.5-3 mm; sepals 5, unequal, oblongobovate to widely elliptic or linear-oblong, 2.3-3 x 1.5-2 mm, well separated from each other at anthesis, apex cuspidate to obtuse, glabrous on inner surface, densely stellate-tomentose on outer surface; petals absent; ovary spheroid, densely stellate-hirsute; styles bifid, with 6 terminal branches, scattered stellate. Capsules spheroid, 3-3.5 mm diam., densely stellate; columella not seen. Seeds ovoid, 2-2.5 x 1.5-1.8 mm, smooth, light brown; caruncle minute, $0.4 \times 0.3 \mathrm{~mm}$. 
Distribution and habitat. Croton amaraliae is distributed in the central-southern Amazon region of Brazil, in the states of Amapá, Amazonas, Mato Grosso, Pará, and Rondônia. It grows in rocky areas of campo cerrado and in sandy areas of Amazonian campina vegetation, from 100-500 m elevation (Fig. 6).

Phenology. Collected in flower and fruit in January, February, April, July, and November.

Etymology. This species is named in honor of Iêda Leão do Amaral, a researcher from the Instituto Nacional de Pesquisas da Amazônia (INPA) who has contributed to the floristic knowledge of the Amazonian region with her numerous plant collections.

Preliminary IUCN Red List category. Croton amaraliae is a sporadic species distributed across five Brazilian states. It is known from four general localities, three of which are represented by a single known collection. It is associated with rocky and sandy habitats which are less likely to be affected by human activities than less rocky or more fertile areas. If a more formal assessment were performed, the species conservation category could range from Least Concern (LC) to Vulnerable (VU).

Notes. Specimens of this species are quite consistent in appearance and can be recognized by their ovate leaves with an acute apex, cordate base, and crenate margins with short-stipitate nectary glands in the sinuses that are often visible from the upper surface. Croton amaraliae is morphologically most similar to C. parodianus (Fig. 2B, C \& D; see also differences in diagnosis above), and in the molecular analyses it is most closely related to $C$. abaitensis and C. almadinensis, both Brazilian members of Clade A (Fig. 3). It also resembles $C$. spica, but that species has longer, elliptic leaves with a rounded to slightly cordate base, sessile petiolar nectary glands, and sessile pistillate flowers.

Paratypes. BRAZIL. Amapá ("Pará" on label; the locality was formerly part of Pará): Jari, Agua Branca, km 3, 28 Jul. 1969, N. T. Silva 2481 (MO, NY). Amazonas: Savanna ca. $15 \mathrm{~km} \mathrm{SW}$ of Humaitá $(10 \mathrm{~km} \mathrm{SW}$ of turn to Humaitá on Manaus-Pôrto Velho highway), 18 Jan. 1978, W. R. Anderson 11800 (DAV 121062, INPA 98361, NY); Humaitá, estrada para VelhoHumaitá (BR-319, km 675), 7³1'S, 6310'W, 5 Apr. 1976, M. R. Estrela \& W. Bellusci 94-5476 (INPA 56800, SP); Humaitá, BR 319, Rod. ManausPôrto Velho, $15 \mathrm{~km}$ de Humaitá, $7^{\circ} 40^{\prime} \mathrm{S}, 6^{\circ} 00^{\prime} \mathrm{W}, 10$ Apr. 1985, C. A. Cid Ferreira 5392 (HRCB, INPA 126856, MO 4242129, NY); Humaitá, 21 Apr. 1976, O. P. Monteiro \& J. Ramos 868 (INPA 59324, MO 2937455). Mato

Grosso: Serra do Cachimbo, BR163, Cuiabá-Santarém Highway, km 768.5 S of Mato Grosso-Pará, open rocky area, 490 m, 12 Nov. 1977, G. T. Prance, A. S. Silva, C. C. Berg, A. J. Henderson, B. W. Nelson, M. Balick, R. P. Bahia, M. $R$. dos Santos P25277 (DAV 106397, DAV 107429, MG, MO 5698232, NY, SP, UEC). Rondônia: Porto Velho, Serra dos Parecis, estrada Guajará-MirimAbunã, km 11, 3 Feb. 1983, L. Carreira, R. Lisboa, M. G. Silva \& C. S. Rosário 503 (IAN, INPA 131875, MO, NY). 
Croton cuadrosii P. E. Berry, sp. nov. TYPE: Colombia. Bolívar: Municipio Santa Rosa de Simití [currently Municipio Santa Rosa del Sur], Inspección Los Canelos [currently Corregimiento Los Canelos], 700 m, 25 May 1986, fl., H. Cuadros 2643 (holotype, MO!; isotypes, F!, JBGP!). Figure 8.

Diagnosis. Croton cuadrosii differs from other members of Croton sect. Geiseleria in its large $(7-14 \times 3.5-11 \mathrm{~cm})$, long-petiolate $(3-8 \mathrm{~cm})$, sometimes trilobed leaves, large stipules $(6-8 \mathrm{~mm} \times 5-7 \mathrm{~mm})$, and prominent pistillate bracts $(5-8 \times 3-4 \mathrm{~mm})$; in leaf size it is close to $C$. kallunkiae, but differs from that species in its shorter inflorescences $(3-6 \mathrm{~cm}$ vs. ca. $12 \mathrm{~cm}$ in C. kallunkiae), and larger stipules (6-8 $\mathrm{mm}$ x 5-7 mm vs. stipules linear and 2-3 mm long in C. kallunkiae).

Shrub (height unknown), monoecious; young branches with scattered, appressed, white to yellowish, stellate-lepidote trichomes; latex not reported. Leaves ovate-deltoid, 7-14 x 3.5-11 cm, some 3-lobed like a Gossypium leaf, apex acute to acuminate, base rounded, margin irregularly serrate, with scattered stipitate nectary glands (6-10 per side) in some sinuses, curved colleters (not nectariferous glands) at each tooth apex; both marginal nectaries and colleters falling off from mature leaves; venation palmate-pinnate, brochidodromous, with 3 main veins radiating from base and 2 fainter veins outside these 3, then 5-6 widely spaced pairs of veins parting from midvein; both surfaces with tiny, scattered, subrosulate trichomes, sometimes with a longer porrect ray, denser along veins; petioles $3-8 \mathrm{~cm}$, scattered stellatelepidote, with 1(2) acetibuliform nectary glands at apex (when 2, sometimes both paired on one side of petiole instead of on opposite sides, other times on opposite sides); stipules cordiform, slightly recurved, 6-8 $\mathrm{mm}$ x 5-7 $\mathrm{mm}$, caducous but leaving a prominent stipular scar. Inflorescences terminal, 3-6 $\mathrm{cm}$, rachis stellate, proximal pistillate cymules 1-flowered, distal cymules staminate and 1-flowered; bracts narrowly deltoid, 5-8 x 3-4 mm (pistillate flowers), base slightly auriculate, glabrate, those of staminate flowers much smaller and awl-shaped, ca. 3 x $1 \mathrm{~mm}$. Staminate flowers with pedicel 2-2.5 $\mathrm{mm}$; sepals 5, valvate, ovate, ca. 2 x 2.5-3 mm, apex acute, subglabrous on inner surface, sparsely stellate-lepidote on outer surface; petals 5, oblongelliptic, $2-2.5$ x ca. $1 \mathrm{~mm}$, subglabrous on inner surface, slightly stellate on outer surface, ciliate along margins; receptacle villous; stamens 10, anthers ca. $0.9-1 \times 0.8-0.9 \mathrm{~mm}$. Pistillate flowers with pedicel 2-3 $\mathrm{mm}$; sepals 5, slightly unequal, narrowly ovate, $2.5-4.5$ x 5-6.5 mm, imbricate, apex acute, glabrous on inner surface, sparsely stellate on outer surface, mostly at base; petals absent; ovary spheroid, densely stellate-porrect; styles tetrafid, with 12 terminal branches, glabrous. Capsules and seeds not seen.

Distribution and habitat. Croton cuadrosii is currently known only from the type collection in southern Departamento Bolívar, Colombia, at 700 $\mathrm{m}$ elevation. This lies in the northernmost extension of the Cordillera Central, west of the Río Magdalena (Fig. 6).

Phenology. Collected once in flower in May. 
Etymology. This species is named in honor of Hermes Cuadros, indefatigable Colombian botanist and collector.

Preliminary IUCN Red List category. Since the southern extreme of Departamento Bolívar in Colombia is quite poorly collected, we do not know the actual range or abundance of this species, so we recommend that until better plant surveys can be made in the region, it should be classified as Data Deficient (DD).

Notes. Even though this species is known only from the type collection, it is unmistakable from all other members of $C$. sect. Geiseleria in its large ovate to trilobed leaves with conspicuous stipules and inflorescence bracts. Its leaves actually resemble some members of arborescent clades of Croton, such as $C$. sections Luntia (Neck. ex Raf.) G. L. Webster (e. g., $C$. palanostigma Klotzsch) and Cyclostigma (e. g., C. gossypifolius Vahl), but it is described as a shrub.

Croton curculiospermus Riina, sp. nov. TYPE: Bolivia. Cochabamba: Mizque, Pasorapa, $5 \mathrm{~km}$ de Pasorapa; sobre el camino a Pasorapillo, $18^{\circ} 18.19^{\prime} \mathrm{S}, 64^{\circ} 38.20^{\prime} \mathrm{W}, 2153 \mathrm{~m}, 21$ Feb. 2003, J. R. I. Wood, \& M. Mendoza 19161 (holotype, USZ!; isotypes, K!, LPB!). Figure 9.

Diagnosis. Croton curculiospermus Riina is most similar to $C$. grewioides Baill., but differs in having oblongoid, laterally compressed seeds with a strong constriction at the apex (vs. ovoid dorso-ventrally compressed seeds lacking a constriction towards the apex in C. grewioides), and lanceolate leaves (vs. ovate to broadly ovate in $C$. grewioides).

Shrub up to $2.5 \mathrm{~m}$ tall, monoecious; young branches with a dense indumentum of yellow-brown, stellate-porrect trichomes; latex not reported. Leaves lanceolate 3.1-3.5 x $1.2 \mathrm{~cm}$, membranaceous, discolorous, apex acute, base acute, margin slightly crenate, marginal nectaries lacking, colleters (not nectariferous glands) scattered along margin, colleters usually falling off from mature leaves; venation pinnate, brochidodromous, with 5-8 pairs of secondary veins; leaf adaxial surface scattered stellate or glabrescent, abaxial side densely stellate-porrect; petioles 4-5 mm, stellate-porrect, with 2 shortstipitate nectary glands at apex; stipules linear, minute, $6-8 \mathrm{~mm}$, caducous. Inflorescences terminal, $4.5-6 \mathrm{~cm}$, erect, rachis stellate-porrect, proximal pistillate cymules 1-flowered, only scars present on distal staminate cymules; bracts early deciduous, not seen. Staminate flowers not seen. Pistillate flowers (in fruit) with pedicel 2.6-3 mm; sepals 5, unequal, linear-lanceolate, 3-4 x $0.3-0.9 \mathrm{~mm}$, apex acute, glabrous on inner surface, sparsely stellate-porrect on outer surface; petals filiform, highly reduced, with a glandular tip (colleter); ovary and styles not seen. Capsules subspheroid, ca. $5 \mathrm{~mm}$ diam. (most already split open), sparsely stellate, columella persistent. Seeds oblongoid, with a conspicuous constriction at apex (resembling a Curculionidae beetle), $3.5-4$ × 2-2.1 mm, surface smooth, light brown; caruncle reniform, ca. 1 x 0.9 $\mathrm{mm}$. 
Distribution and habitat. Croton curculiospermus is only known from the type locality in Cochabamba Province, Bolivia. According to the collection label, the species is locally abundant in open dry forest on a rocky (sandstone) hill, around $2150 \mathrm{~m}$ elevation (Fig. 6).

\section{Phenology. Fruiting in February.}

Etymology. The species epithet refers to the shape of the seeds, which resemble the body of snout beetles (Curculionidae; Fig. 9B \& C).

Preliminary IUCN Red List category. We recommend that this species be considered Data Deficient (DD) at this time, since it is only known from the type specimen, in an area of Bolivia that is still very poorly collected.

Notes. The ITS phylogeny (Fig. 3) indicates that Croton curculiospermus is closely related to C. grewioides in Clade A. Besides the morphological differences included in the diagnosis, C. curculiospermus occurs at higher elevations $(2150 \mathrm{~m})$ than $C$. grewioides $(200-1390 \mathrm{~m})$. Because plants of $C$. grewioides have a very characteristic clove-like odor when the leaves are crushed, this feature should be checked when additional collections of $C$. curculiospermus can be obtained. Croton curculiospermus is also superficially similar to $C$. avulsus Croizat, another species known only from Bolivia and occurring at high elevations (2500-3000 m), but belonging to a different clade, $C$. sect. Barhamia (Klotzsch) Baill. Besides the difference in seed shape, $C$. curculiospermus differs from $C$. avulsus in having leaves that are 3.1-3.5 cm long (vs. 1-1.4 cm long in C. avulsus), petiolar nectary glands (absent in C. avulsus), and lax inflorescences that are $4.5-6 \mathrm{~cm}$ long (vs. compact inflorescences that are $0.4-0.6 \mathrm{~cm}$ long in C. avulsus).

Croton huamaliensis Riina, sp. nov. TYPE: Peru. Huánuco: Huamalias, Maquizapa (carretera Monzón), 700 m, 18 Feb. 1966, J. Schunke-Vigo 1098 (holotype, MICH!; isotypes, AMES!, DAV-89230!, DAV-105887!, F!, MA!, NY - 2 sheets!). Figure 10.

Diagnosis. Croton huamaliensis is most similar to C. brevipes, but differs by the eglandular leaf margins (vs. obvious presence of stipitate marginal glands in $C$. brevipes) and smaller capsules 4-4.2 $\mathrm{mm}$ long, with a denser indument of conspicuous stellate-porrect trichomes (vs. capsules 4.8$5.3 \mathrm{~mm}$ long, with scattered inconspicuous stellate-porrect trichomes in $C$. brevipes).

Shrub 2-3 m tall, monoecious; young branches with a dense indumentum of pale, stellate-porrect trichomes; latex not reported. Leaves ovate to lanceolate, 3.9-7.4 x 2.7-4.9 cm, membranaceous, discolorous, apex acute, base rounded, margin crenate-dentate, nectary glands in sinuses apparently absent, curved colleters (not nectariferous glands) scattered along margin; both marginal nectaries and colleters generally falling off from oldest leaves; venation pinnate, brochidodromous, with 4-5 pairs of secondary veins, leaf adaxial surface covered sparsely stellate-porrect, appearing simple with age (only main porrect ray remaining), abaxial surface with a densely stellate- 
porrect; petioles $0.2-1.2(-2.5) \mathrm{cm}$, stellate-porrect, with 2 stipitate nectary glands at apex; stipules linear-triangular, $1.8-3 \mathrm{~mm}$, persistent. Inflorescences terminal, rarely axillary, $1.5-3 \mathrm{~cm}$, erect, rachis stellate-porrect, proximal cymules pistillate and 1-flowered, distal staminate cymules 1- or 2-flowered; bracts narrowly triangular to linear, $1.2-2 \mathrm{~mm}$, sometimes lobed at base, stellate-porrect. Staminate flowers with short pedicels 1-1.8 mm long; sepals 5 , valvate, ovate, $1-1.3 \times 0.3-0-4 \mathrm{~mm}$, apex acute, glabrous on inner surface, stellate-porrect on outer surface; petals 5, elliptic to oblong-elliptic, 1.3-1.6 x 0.4-0.6 mm, subglabrous on inner surface, glabrous on outer surface, ciliate along upper margins; receptacle villous; stamens 10-11, anthers $0.4-0.5 \mathrm{x}$ $0.3-0.4 \mathrm{~mm}$. Pistillate flowers with pedicels $3-4.5 \mathrm{~mm}$; sepals 5 , slightly unequal, lanceolate, 4-5.2 x 0.8-1 mm, well separated from each other at anthesis, apex acute, glabrous on inner surface, sparsely stellate-porrect on outer surface; petals highly reduced to minute appendages with a glandular tip (colleter); ovary spheroid, densely stellate-porrect; styles bifid from the base (with six main branches), and the tips of most branches then each shortly bifurcate, giving ca. 12 terminal tips, scattered stellate-porrect. Capsules spheroid, 4-4.2 mm diam., sparsely stellate-porrect; columella and seeds not seen.

Distribution and habitat. The species is only known from the type locality in the Department of Huánuco, Peru, where it is found in forests at 700 m elevation (Fig. 6).

Etymology. The species is named after Huamalias Province in Huánuco Department, where the type was collected.

Preliminary IUCN Red List category. We recommend that this species be considered Data Deficient (DD) at this time, because it is known from a single locality in an area of Peru that is still very poorly collected.

Notes. Croton huamaliensis is morphologically most similar to $C$. brevipes from northern Colombia, Central America and Mexico (see diagnosis). In the ITS phylogeny (Fig. 3), it is a member of Clade C and is sister to a clade consisting of C. brevipes and the Mexican C. macrodontus.

Croton kallunkiae Riina \& Caruzo, sp. nov. TYPE: Brazil. Espírito Santo: Piuma, roadside at base of Morro Agá, ca. $5 \mathrm{~km} \mathrm{~S}$ of Piuma on Rod. ES60, 2052'S, 4046’W, 18 Jan. 1993, J. A. Kallunki \& J. R. Pirani 332 (holotype, SP!; isotypes, SPF!, MO!, NY!). Figure 11.

Diagnosis. Croton kallunkiae differs from almost all other species of $C$. sect. Geiseleria in its large stature (large shrubs to small trees up to $5 \mathrm{~m}$ tall), long inflorescences (ca. $12 \mathrm{~cm}$ long), and large, long-petiolate leaves (3$9.5 \times 4-7 \mathrm{~cm}$, with petioles $1.5-3.5 \mathrm{~cm}$ long); within $C$. sect. Geiseleria it is closest in these respects to C. cuadrosii, but that species has some trilobed leaves (vs. unlobed), shorter inflorescences (3-6 cm long), much larger pistillate bracts (5-8 $\mathrm{mm}$ long vs. $1 \mathrm{~mm})$, and tetrafid styles (vs. bifid). 
Shrubs to small trees, up to $5 \mathrm{~m}$ tall, monoecious; young branches pubescent with pale multiradiate-porrect trichomes; latex not reported. Leaves ovate to subdeltoid, 3-9.5 x 4-7 cm, chartaceous, strongly discolorous, apex acute to rounded, base rounded to slightly cordate, margin denticulate to irregularly serrate, with tiny stipitate nectary glands usually present in sinuses, colleters (not nectariferous glands) spaced along margin alternating with nectaries; both marginal nectaries and colleters falling off from mature leaves; venation palmate-pinnate, brochidodromous, with 6-8 veins radiating from base; leaf adaxial surface glabrescent to glabrous, sparsely appressed-stellate and with multiradiate-porrect trichomes along midvein, abaxial surface with a moderately dense indumentum of appressed-stellate and stellate-porrect trichomes; petioles $1.5-3.5 \mathrm{~cm}$, multiradiate-porrect, with 2 short-stipitate nectary glands at apex; stipules linear, 2-3 mm, caducous. Inflorescences terminal, ca. $12 \mathrm{~cm}$, erect, rachis striate, stellate-porrect, proximal cymules pistillate and 2- or 3-flowered, distal cymules staminate and 3- or 4-flowered; bracts linear-lanceolate, ca. $1 \mathrm{~mm}$, stellate. Staminate flowers with short pedicel 1-3 mm; sepals 5, subequal, valvate, ovate, 1.5-2 x 1-1.2 mm, apex acute, sparsely stellate to glabrous on inner surface, sparsely to densely stellate on outer surface; petals 5, elliptic, ca. $2 \times 0.5-1 \mathrm{~mm}$, ciliate, glabrate on inner and outer surfaces; receptacle villous; stamens 10, 2-3 mm, anthers $0.5-1 \mathrm{x}$ 0.5-1 mm. Pistillate flowers with short pedicel 0.5-1.2 mm long; sepals 5, unequal, spathulate, $3-3.5 \times 1-1.8 \mathrm{~mm}$, valvate, apex slightly acute and cucculate, sometimes rounded, almost glabrous on inner surface, densely stellate-porrect trichomes on outer surface; petals absent; ovary spheroid, densely stellate-porrect, styles bifid, with 6 terminal branches, sparsely stellate. Capsules and seeds not seen.

Distribution and habitat. The species is only known from Espírito Santo and southern Bahia states, Brazil. It occurs on or around granitic inselbergs in Espírito Santo and on rocky outcrops in southern Bahia Atlantic coastal forest, at elevations of 100-900 m (Fig. 6).

Phenology. Croton kallunkiae has been collected in flower and fruit in January, March, September, October, and November.

Etymology. This species is named after our colleague from the New York Botanical Garden, Jacquelyn (Jackie) Kallunki, in recognition not only of her taxonomic expertise in Rutaceae but also her keen observations on other Neotropical groups like Croton. Many undetermined Croton specimens at NY were initially noted by Jackie as being unusual, and later several of them were described by various Croton specialists as new species.

Preliminary IUCN Red List category. Croton kallunkiae is a specialist species on granitic inselbergs or rock outcrops, with a single report from southern Bahia state and more numerous reports from inselbergs in Espírito Santo. Several of the reports come from the capital area of Vitória, so they can be considered in danger of encroachment by human activities. It is likely that further study would show this species to warrant a category of either Vulnerable (VU) or Near Threatened (NT). 
Notes. Croton kallunkiae is quite distinctive in C. sect. Geiseleria by its large stature (the type specimen is described as a tree to $5 \mathrm{~m}$ tall), with large leaves, long petioles, and long inflorescences. In these respects, it most closely resembles some members of the arborescent $C$. sect. Cyclostigma, in fact, the type specimen of C. kallunkiae (Fig. 11a) was initially determined as similar to C. draconoides Müll. Arg. (a species in C. sect. Cyclostigma). However, characters such as the presence of marginal nectary glands and the absence of bisexual cymules in C. kallunkiae strongly indicate that the species does not belong in that section. This is corroborated by the ITS analysis (Fig. 3 ), where it is recovered within sect. Geiseleria and most closely related to $C$. arenosus. Although the single accession of $C$. arenosus renders the two accessions of C. kallunkiae paraphyletic (Fig. 3), the two species are morphologically very distinct, with $C$. arenosus having much smaller, pinnately veined leaves just $0.9-2.5 \times 0.8-2 \mathrm{~cm}$ (vs. basally palmately veined leaves 3-9.5 x 4-7 cm), petioles just 2-5 mm long (vs. 20-45 mm), and inflorescences $2-4.5 \mathrm{~cm}$ long (vs. ca. $12 \mathrm{~cm}$ long).

Paratypes. BRAZIL. Bahia: Município de Itamaraju, Fazenda Paubrasil, ca. $5 \mathrm{~km}$ a NW de Itamaraju, Mata higrófila Sul Baina, perturbada, afloramento de rochas na área, 19 Sep. 1978, S. Mori, L. A. Mattos Silva \& T. S. dos Santos 10722 (CEPEC, DAV, NY). Espírito Santo: Águia Branca, Comunidade São Pedro, propriedade do Sr. João Ferreira, Pedra da Bandeira, 18 58'50'S, 40³9'41'’W, 252 m, 17 Jan. 2008, M. M. Saavedra, C. N. Fraga, R. F. Monteiro \& M. C. Souza 679 (MBML, RB, SP); Vitória, arredores da capital, 17 Nov. 1964, A. P. Duarte 8473 (RB); Vitória, Campus da UFES, 20 Jun. 1989, O. J. Pereira, O. J. F. Passamani \& J. M. L. Gomes 2053 (VIES 4629); Vitória, Av. Nossa Senhora da Penha, próximo a pedreira, floresta de tabuleiro, $20.3197^{\circ} \mathrm{S}, 40.3375^{\circ} \mathrm{W}, 21$ Oct. 1985, L. C. Fabris 13 (VIES); Vitória, Serra do Maruipe, 20 Mar. 1934, J. G. Kuhlmann 10 (RB); Vitória, Morro do Itapenambi, 13 Aug. 1991, S. V. Pereira, J. M. Simoes, M. L. L. Martins 104 (VIES); ibid., 105 (VIES); ibid., 106 (VIES); Burarama, Cachoeiro de Itapemirim, $20.6808^{\circ} \mathrm{S}, 41.3467^{\circ} \mathrm{W}, 183 \mathrm{~m}, 28$ Mar. 2012, D. $R$. Couto, F. C. Favoreto 2146 (VIES 33798); Ibiraçu, 28 May 1990, H. Q. B. Fernandes 2972 (VIES); Itarana, Alto Várzea Alegre, Pedra da Onça, inselbergue, 1953'45'S, 4048'46' 'W, 892 m, 19 Apr. 2013, R. C. Forzza, J. A. Amaral \& M. O. O. Pellegini 7531 (RB, VIES 23534); Barra da Rapadura, Fazenda do Sr. Wagner Scardini, inselbergue, 1842'26’S, 40³5’35'’W, 155 m, R. C. Forzza, K. Hmeljevski, H. Medeiros 7872 (VIES, RB, SP); Santa Teresa/Itarana, Pedra do Cruzeiro, 900 m, 10 Nov. 1998, L. Kollmann, E. Bausen \& W. Pizziolo 974 (MBML 9387); Barra de São Francisco, estrada Ecopóranga/Barra de São Francisco, 18³2'21"S, 4049'1"W, 10 Sep. 2009, L. Kollmann \& E. Leme 11829 (MBML 39340).

Croton pluriglandulosus Carn.-Torres \& Riina, sp. nov. TYPE: Brazil. Ceará: Guaraciaba do Norte, Chapada da Ibiapaba, 6 Apr. 1984, (fl., fr.), A. Fernandes \& P. Matos s.n. (holotype, HUEFS-106386!; isotypes, EAC12440!, HUEFS-111094!). Figure 12.

Diagnosis. Croton pluriglandulosus is similar to C. triangularis Müll. Arg., but differs in having 6-10 acropetiolar nectary glands, spreading 
pistillate sepals, styles with 6 terminal branches, and capsules 5-6 mm diam. (vs. 2 acropetiolar glands, pistillate sepals revolute towards the apex, styles with ca. 12 terminal branches, and capsules $8-9 \times 7-8 \mathrm{~mm}$ in C. triangularis).

Shrubs up to $4 \mathrm{~m}$ tall, monoecious; young branches with usually apressed-stellate and dark stellate-porrect trichomes; latex translucent. Leaves ovate, 5-11.5 x 3-8 cm, membranaceous, slightly discolorous, apex acuminate, base cordate, margin crenate, with tiny sessile nectary glands usually present in sinuses, colleters (not nectariferous glands) scattered along margin alternating with nectaries; both marginal nectaries and colleters often falling off from mature leaves; venation palmate-pinnate, brochidodromus, with 6-8 pairs of secondary veins, leaf adaxial surface sparsely appressedstellate and stellate-porrect, abaxial surface sparsely stellate-porrect; petioles $1.5-4.5 \mathrm{~cm}$, apressed-stellate to stellate-porrect, with 6-10 stipitate nectary glands at apex, two with stipes conspicuously longer than others (up to 4.7 $\mathrm{mm}$ long); stipules linear-lanceolate, 5-7 mm, caducous. Inflorescences terminal, 5.5-2 cm, erect, rachis appressed-stellate to stellate-porrect, proximal pistillate cymules 1 -flowered, distal staminate cymules 3-4flowered; bracts lanceolate, $2-3 \mathrm{~mm}$, stellate. Staminate flowers with short pedicel 1-2 mm; sepals 5, valvate, oblong, 2-3 x 2-3 mm, apex acute and ciliate, glabrous on inner surface, sparsely apressed-stellate on outer surface; petals 5, oblong, 2-3 x 2-3 mm, densely villous-lanate on inner surface, sparsely villous on outer surface; receptacle villous; stamens 10, 2-3 mm, anthers $0.2-0.3 \times 0.2-0.3 \mathrm{~mm}$. Pistillate flowers with short pedicels $1-2 \mathrm{~mm}$; sepals 5, equal, oblong, spreading, $4-5 \times 2-3 \mathrm{~mm}$, valvate, apex acute to rounded, stellate-hispid on inner surface, stellate-hispid on outer surface; petals usually reduced to small glands; ovary spheroid, sparsely stellateporrect; styles bifid, with 6 terminal branches, glabrous. Capsules spheroid, 5$6 \mathrm{~mm}$ diam., sparsely stellate to glabrous; columella persistent. Seeds spheroid-oblongoid, 4-5 x 3-4 mm, surface smooth, dark brown; caruncle inconspicuous.

Vernacular names. Marmeleiro sabiá, Marmeleiro, and Marmeleiro branco.

Distribution and habitat. This species is known from Ceará, Paraíba, Pernambuco, Piauí, Rio Grande do Norte, and Sergipe states in Brazil, where it grows in dry forest (Caatingas) on sandy and stony soil at $100-800 \mathrm{~m}$ elevation (Fig. 6).

Phenology. It has been collected with flowers and fruits from January to October.

Etymology. Croton pluriglandulosus is named for its multiple acropetiolar glands.

Preliminary IUCN Red List category. Due to its wide distribution and numerous localities in Caatinga vegetation, we consider that if a formal assessment were performed, this species would be classified as Least Concern (LC). 
Notes. Croton pluriglandulosus can be recognized by its 6-10 stipitate acropetiolar nectary glands, with two of them much longer than the rest (Fig. $12 \mathrm{G})$. It is morphologically most similar to C. triangularis, a species from the Cerrado region of Bahia and Minas Gerais states (see diagnosis), but the two species are recovered as distantly related within the section in both phylogenies (Figs. 3 \& 4), with $C$. pluriglandulosus in Clade A and $C$. triangularis in Clade D. Some herbarium specimens of C. pluriglandulosus have been misidentified as $C$. anisodontus Müll. Arg. (e.g., Carneiro-Torres et al. 858, HUEFS) and C. pseudopopulus Baill. (e.g., Pickel 2346, IPA, MICH). Both species can be easily distinguished from C. pluriglandulosus because they have only one pair of acropetiolar nectary glands and more than 16 stamens (vs. 6-10 acropetiolar nectary glands and 10 stamens in $C$. pluriglandulosus). In addition, C. pseudopopulus has bisexual cymules, suggesting that it may belong to $C$. sect. Cyclostigma.

The ITS phylogeny recovers Croton pluriglandulosus sister to the Cuban and Hispaniolan C. pachysepalus with strong support within Clade A (Fig. 3). These two species are remarkably different, with C. pluriglandulosus having some of the largest leaves within the section and C. pachysepalus having among the smallest. The branch leading to the two accessions of $C$. pachysepalus is the longest branch subtending a species (or an accession) in the section (other than the potentially problematic $C$. macrosepalus and $C$. spica accessions), and that was also the case in the analyses of Van Ee et al. (2011) in which C. pachysepalus was included.

Paratypes. BRAZIL. Ceará: Acarape, Sítio Garapa, 413'27' 'S, 3842'30'’W, 27 Mar. 2012, E. Silveira s.n. (ALCB 106148, EAC 33741); Aracati, 4033'42''S, 37²6'11' 'W, 3 Apr. 1977, A. Fernandes \& P. Matos s.n. (EAC 3131); Capistrano, Fazenda Araçanga-Serra de Baturité, 4'28'12'’S, 38 54'05' 'W, 27 Apr. 1994, J. B. L. P. Medeiros \& M. A. Figueiredo 51 (HUEFS, EAC); Caucaia, 344'10' 'S, 38³9'11'’W, 23 Apr. 1999, L. W. Lima-Verde s.n. (EAC 27711); Cratéus, $15 \mathrm{~km}$ do Portão Principal da RPPN Serra das Almas, 5¹3'16' 'S, 4056'42' 'W, 11 Feb. 2007, D. S. CarneiroTorres et al. 858 (HUEFS); Granja, Santa Terezinha, localidade São Miguel (Cachoeira), 3'21'32''S, 411'24' 'W, 15 Mar. 2017, E. B. Souza et al. 4464

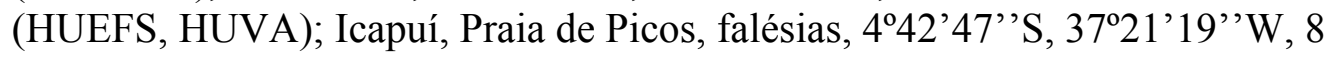
Feb. 1997, A. S. F. Castro 333 (EAC); Ipu, Chapada da Ibiapaba, 4¹9'20's, 4042'39' 'W, 30 Apr. 1994, A. Fernandes \& P. Matos s.n. (EAC 21208, IPA 64235); Itapiúna, Sítio Itapiúna, 4³3'52' 'S, 3855'20' 'W, 1 Apr. 2011, H.S. Santos s.n. (EAC 48964); Maranguape, Cedro, 3'53'27''S, 3841'08'’'W, 16 May 2001, G. N. Maia s.n. (EAC 30770); Morada Nova, Fazenda Lagoa Funda, 506'24' 'S, 38²2'21' 'W, 15 Apr. 1983, E. Nunes \& R. P. Soares s.n. (HUEFS 106394, EAC 11873); Novo Oriente, Bom Sucesso, 5³2'04''S, 4046'27', W, 6 Mar. 1990, F. S. Araújo s.n. (HUEFS 106409, EAC 17264, IPA 64234); Pentecoste, Faz. Canaã, 347'34'’S, 39¹6'13'’W, 18 Jun. 2008, R. G. Ferreira 356 (EAC); Quixadá, Santuário Nossa Senhor Rainha do Sertão, 458'17''S, 3900'55' 'W, 6 May 1995, E.B. Lima et al. s.n. (HUEFS 111110, EAC 23715); São Gonçalo do Amarante, 3³6'26' 'S, 3858'06' 'W, 10 Mar. 2000, H. Magalhães 170 (EAC); Sobral, Serra da Meruoca, subida para a bica da Marina, 337'38''S, 40²4'02' 'W, 7 Apr. 2016, E. B. Souza et 
al. 3914 (HUEFS, HUVA); distrito de Taperoaba, Pedra da Andorinha, 4'3'51' 'S, 3959'51' 'W, 6 Jan. 2017, F. F. Araújo 97 (HUEFS, HUVA); Sítio Santo Inácio, $3^{\circ} 35^{\prime} 40.65^{\prime}$ 'S , 40'24'11.91' 'W, 11 Aug. 2013, J. E. M. Nascimento 30 (HUEFS, HUVA); Tianguá, Chapada da Ibiapaba, 343'56' 'S, 4059'30'’W, 30 Apr. 1987, A. Fernandes \& P. Matos s.n. (HUEFS 111099, EAC 15074); Viçosa do Ceará, Chapada da Ibiapaba, Cocalzinho, 333'44' 'S, 41'5'32''W, 6 Apr. 1984, A. Fernandes \& P. Matos s.n. (HUEFS 106385, EAC 12439); 19 Feb. 1977, (buds), A. Fernandes \& P. Matos s.n. (HUEFS 111111, EAC 3101). Paraíba: Junco do Seridó, sobre morro de micaxisto, 6'59'48'’S, 36 42'47' 'W, 22 Apr. 1978, D. Andrade Lima 8372 (IPA, HUEFS). Pernambuco: Caruaru, Sítio Pedra da Torre, na subida para o cruzeiro, propriedade de José Aleixo Sobrinho, 8'17'00' 'S, 35'58'34' 'W, 18 Apr. 1997, A. Laurênio et al. 478 (PEUFR); Flores, 752'05' 'S, 3758'29' 'W, 28 Mar. 1970, D. Andrade-Lima 70-5849 (IPA); Tapera, 23 May 1930, D. B. Pickel 2346 (IPA, MICH). Piauí: Cachoeira do Urubu, 356'36' 'S, 42 ${ }^{\circ}$ '88' 'W, 2 Apr. 2015, E. R. Silveira \& F. C. L. Pinto 4 (ALCB); São João da Fronteira, 3'55'67''S, 41¹7'00' 'W, 3 Apr. 2015, E. R. Silveira \& F. C. L. Pinto 1 (ALCB); Padre Marcos, 7²1'18''S, 4054'16' 'W, 24 Jan. 1994, M. E. Alencar s.n. (EAC 20717). Rio Grande do Norte: Acarí, 6²3'35,6's, 36³6'33,5' 'W, 16 Apr. 2007, L. P. Félix 11788 (EAC, HUEFS); Jandaíra, Estação Ecológica de Terras Secas, 5²1'23' 'S, 377'41' 'W, 13 May 1986, S. H. Vasconcelos 34 (MOSS); Mossoró, campus da ESAM, 5'11'31'’S, 37²0'40' 'W, 2 Apr. 1979, O. F. de Oliveira 649 (MOSS); São Tomé, Fazenda Ingá, 553'00'’S, 3602'00' 'W, 13 Apr. 1980, O. F. de Oliveira 263

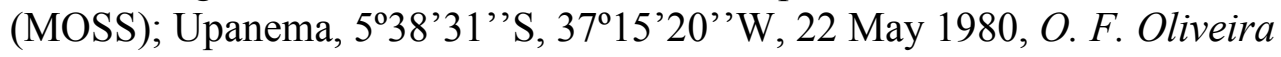
824 (MOSS). Sergipe: Areia Branca, povoado Caroba, 1045'28'’S, $37^{\circ} 18^{\prime} 55^{\prime}$ 'W, 13 Oct. 2009, J. S. Lima 140 (ASE).

\section{$\underline{\text { Revised Synopsis of Croton section Geiseleria }}$}

Here we provide an updated listing of all species that are now considered to belong to Croton section Geiseleria, followed by a brief discussion of why we exclude several species that were treated by Van Ee et al. (2011) or Sodré et al. (2019a) as belonging to the section. We also recognize four morphologically and molecularly supported subsections. Three of these, C. subsects. Geiseleria, Ocalia, and Podostachys, correspond to sections that were recognized by Baillon (1858) and Webster (1993) but were subsequently lumped into $C$. sect. Geiseleria by Van Ee et al. (2011). Croton subsect. Brasilienses is newly described here.

This alphabetical list provides pertinent nomenclatural information, including types and synonyms, as well as geographical distributions by country and by state for larger countries such as Brazil and Mexico. Additional notes are also provided, when needed, to clarify particular issues or for circumscriptions that are different from those provided for Brazilian species in Sodré et al. (2019a). For full sectional synonymy and sectional descriptions, see Van Ee et al. (2011: 815) and Sodré et al. (2019a: 21). Figure 1 gives a breakdown of the number of species and endemics per country or area in the New World, highlighting that Brazil and Mexico stand out for the highest number of species, as well as endemics, in the section. 
Given the high number of species in this section and its wide distribution in the Americas, it is likely that additional new species belonging to it will be discovered in the future. Also, the circumscription of several species will need to be studied in further detail, in particular widespread and variable ones such as Croton antisyphiliticus, C. glandulosus, and $C$. lundianus.

Croton sect. Geiseleria (A. Gray) Baill., Étude Euphorb.: 359. 1858. Croton subg. Geiseleria A. Gray, Manual, ed. 2: 391. 1856. TYPE: Croton glandulosus L.

Diagnostic description. Herbs, subshrubs, shrubs, or small trees to $5 \mathrm{~m}$ tall, monoecious; trichomes stellate or variations thereof (stellate-porrect, multiradiate, fasciculate, stellate-rotate, or reduced to simple). Leaves simple, alternate or sometimes opposite or subopposite to subverticillate at the di- or trichotomy of branches or below inflorescences, with 2, 4 (-8) usually stipitate (rarely sessile) nectary glands at the apex of the petiole or at the base of the blade (Fig. 2A); margins serrate to crenate (rarely entire), often with sessile or stipitate nectary glands in the sinuses. Inflorescences raceme-like thyrses, generally bisexual, terminal or in the dichotomies or trichotomies of branches, with 1-20 basal pistillate flowers, the distal portion staminate with cymules of 1-6 flowers, continuous or else with a bare sterile zone between the pistillate and staminate sections; bracts frequently with sessile or stipitate glands (usually colleters, rarely nectaries), usually persistent and upcurving on the distal male section even after the flowers dehisce (Fig. 2C \& D). Stamens (5)11(-24). Pistillate flowers actinomorphic to asymmetric, sepals 5(-8), free, unequal or equal in size and shape, valvate in bud, rarely reduplicate; styles bifid, tetrafid, or multifid, with 6-12(-48) terminal stigmatic branch tips. Calyx normally persistent even after the capsule dehisces, then showing a usually cup-shaped receptacle consisting of the basal connate portion of the sepals (Fig. 2E \& F) and a columella with an irregularly fimbriate apex (Fig. 2E).

Distribution and habitat. Fields, roadsides, waste places, open and mostly dry vegetation, deciduous to occasionally moist forests, with several species endemic to open vegetation in white-sand areas of the Amazon basin, widespread in the New World from the United States to Argentina, from sea level to $2150 \mathrm{~m}$ (Fig. 1). Croton glandulosus and C. hirtus are naturalized weeds in Africa, Asia, Indonesia, and Australia.

Notes. Van Ee et al. (2011) listed Pleopadium Raf. as a synonym of Croton sect. Geiseleria, following the synonymization of Pleopadium ciliatum Raf., the type of Pleopadium, by Govaerts et al. (2000) under Croton glandulosus var. septentrionalis. This is clearly incorrect, however, since the protologue of $P$. ciliatum (Rafinesque 1840) describes a plant with rather large staminate flowers having 30-40 stamens. Furthermore it is stated that 'the name [Pleopadium] means many stipitate glands,' and that the genus is 'very close to the genus Kurkas [Raf.].' Other species that Rafinesque listed under his description of Kurkas (Rafinesque, 1838) are all trees or large shrubs, including C. tiglium L., the type of Croton, as well as C. quadrisetosus Lam., 
C. populifolius $[=C$. hircinus Vent.], and C. congestus Lour., among others. The exact taxonomic disposition of Pleopadium would require establishing the identity of $P$. ciliatum through lectotypification.

After a review of the morphological features of the species treated below under $C$. sect. Geiseleria and the results of the molecular phylogenetic analyses shown in Figs. 3 \& 4, we recognize four subsections, which help to show some of the affinities of the species and to group those that share some key features, mainly of the pistillate flowers.

Key to the subsections of Croton section Geiseleria (A. Gray) Baill.

1. Inflorescences with a distinct gap between the pistillate and staminate portions, or else too short and congested to see a gap; sepals of pistillate flowers 6-8, only rarely $5 \ldots$.. . sect. Geiseleria subsect. Podostachys (Klotzsch) Müll. Arg.

1. Inflorescences without a distinct gap between the pistillate and staminate portions, rarely too short and congested to obscure this feature; sepals of pistillate flowers 5 , only rarely $6 \ldots 2$

2. Sepals of pistillate flowers usually distinctly unequal; herbs, shrubs, or small trees ... C. sect. Geiseleria subsect. Geiseleria (A. Gray) B. W. van Ee \& P. E. Berry

2. Sepals of pistillate flowers equal to slightly unequal; shrubs ... 3

3. Sepals of pistillate flowers sometimes with gland-tipped trichomes; half or more of all secondary leaf veins originating from the base of the leaf; leaves ranging from approximately twice as long as wide to much longer than wide (narrow, lanceolate leaves); teeth of leaf margins sometimes with nectary glands ... C. sect. Geiseleria subsect. Brasilienses B. W. van Ee \& P. E. Berry

3. Sepals of pistillate flowers without gland-tipped trichomes; up to half of secondary leaf veins originating from the base of the leaf, usually the majority emerging from the midvein; leaves no more than 2-3 times as long as wide; teeth of leaf margins without nectary glands ... C. sect. Geiseleria subsect. Ocalia (Klotzsch) B. W. van Ee \& P. E. Berry

Note. Species names in bold italics in the following lists of subsections indicates that there is a DNA sequence or sequences included in the phylogenies (Figs. 3 \& 4). Species listed only in italics are included based on morphological features consistent with the respective subsectional description.

Croton subsect. Geiseleria (A. Gray) B. W. van Ee \& P. E. Berry, stat. nov. Croton subg. Geiseleria A. Gray, Manual, ed. 2: 391. 1856. TYPE: Croton glandulosus L.

Decarinium Raf., Neogenyton: 1. 1825. Croton sect. Decarinium (Raf.) Müll. Arg., Linnaea 34: 78. 1865. Croton subg. Decarinium (Raf.) Pax in Engler \& Prantl, Nat. Pflanzenfam. 3(5): 40. 1890. TYPE: Decarinium glandulosum (L.) Raf.[ $\equiv$ C. glandulosus L.].

Brachystachys Klotzsch, London J. Bot. 2: 47. 1843. TYPE: Brachystachys hirta (L’Hér.) Klotzsch [三 C. hirtus L’Hér.]. 
Herbs, shrubs, or small trees to $5 \mathrm{~m}$ tall; inflorescences without a distinct gap between staminate and pistillate portions; sepals of pistillate flowers 5(6), unequal; styles bifid, with 6 terminal branch tips. Clade A in Figs. 3 \& 4 .

Included species (42): C. abaitensis Baill., C. adenodontus (Müll. Arg.) Müll. Arg., C. almadinensis Caruzo \& Riina, $\boldsymbol{C}$. amaraliae Riina \& P. E. Berry, C. arenosus Carn.-Torres \& Cordeiro, C. bidentatus Müll. Arg., C. carandaitensis Croizat, $\boldsymbol{C}$. chamelensis E. J. Lott, $\boldsymbol{C}$. cupulifer McVaugh, $\boldsymbol{C}$. curculiospermus Riina, C. flavoglandulosus Lundell, $\boldsymbol{C}$. glandulosus L., $\boldsymbol{C}$. goyazensis Müll. Arg., C. grewioides Baill., C. harleyi Carn.-Torres \& Cordeiro, C. hirtus L'Hér., C. hostmannii Miq., C. inaequilobus Steyerm., C. itzaeus Lundell, $\boldsymbol{C}$. jutiapensis Croizat, $\boldsymbol{C}$. kallunkiae Riina \& Caruzo, $\boldsymbol{C}$. lagunillae Croizat, C. lotorius Croizat, C. macrosepalus Sodré \& M. J. Silva, C. magniglandulifer (V. W. Steinm.) B. W. Van Ee, C. martinianus, $\boldsymbol{C}$. mollis Benth., C. ortegae Standl., C. ortholobus Müll. Arg., C. pachysepalus Griseb., C. parodian us Croizat, C. planaltoanus M. J. Silva \& Sodré, $\boldsymbol{C}$. pluriglandulosus Carn.-Torres \& Riina, $C$. ramillatus Croizat, $C$. ramosissimus Sodré \& M. J. Silva, C. rhodotrichus Sodré \& M. J. Silva, C. seccoi Sodré \& M. J. Silva, C. spica Baill., C. suavis Kunth, Bonpland \& Humboldt, C. subsuavis Croizat, C. varelae V. W. Steinm., C. virgultosus Müll. Arg.

Croton subsect. Brasilienses B. W. van Ee \& P. E. Berry, subsect. nov. TYPE: Croton mucronifolius Müll. Arg.

Diagnosis. Shrubs; inflorescences without a distinct gap between staminate and pistillate portions; sepals of pistillate flowers 5 (6 in $C$. uliginosus), equal, with gland-tipped trichomes in several species; styles bifid, with six terminal branch tips (12 in C. campinarensis and some populations of C. nepetifolius). Clade B in Figs. 3 \& 4.

Etymology. The subsection is named after Brazil (Brasil, in Portuguese), where all the species are endemic, except for C. nepetifolius, which also occurs in Bolivia.

Included species (14): C. adamantinus Müll. Arg., C. agoensis Baill., C. campinarensis Secco, A. Rosario \& P. E. Berry, C. carinatus Müll. Arg., C. catariae Baill., C. crustulifer Croizat, C. desertorum Müll. Arg., C. gracilirameus M. J. Silva, Sodré \& P. E. Berry, C. junceus Baill., $\boldsymbol{C}$. mucronifolius Müll. Arg., C. nepetifolius Baill., C. pycnadenius Müll. Arg., C. sublepidotus Müll. Arg., C. uliginosus Sodré \& M. J. Silva.

Croton subsect. Ocalia (Klotzsch) B. W. van Ee \& P. E. Berry, stat. nov. Ocalia Klotzsch, Arch. Naturgesch. 7: 195. 1841. Croton sect. Ocalia (Klotzsch) Baill., Étude Euphorb.: 366. 1858. TYPE: C. perdicipes A. St.Hil., designated by Baillon [1858: 366]. [=C. antisyphiliticus Mart.]. Aldinia Raf., Autik. Bot.: 50. 1840. TYPE: A. glechomoides Raf. [= Croton betulinus Vahl]. 
Shrubs; inflorescences without a distinct gap between staminate and pistillate portions; sepals of pistillate flowers 5, (sub)equal; styles bifid or tetrafid, with 6 (most species) or 12 terminal branch tips (C. triangularis). Clade D in Figs. 3 \& 4.

Included species (11): $\boldsymbol{C}$. antisyphiliticus Mart., $\boldsymbol{C}$. asperrimus Benth., C. betulinus Vahl, C. cuadrosii P. E. Berry, C. glechomifolius Müll. Arg., C. gracilescens Müll. Arg., C. malvavisciifolius Millsp., C. mcvaughii G. L. Webster, C. repens Schltdl., C. triangularis Müll. Arg., C. verbenifolius Müll. Arg.

Croton subsect. Podostachys (Klotzsch) Müll. Arg., Linnaea 34: 134. 1865. Podostachys Klotzsch, Arch. Naturgesch. 7: 193. 1841. Croton sect. Podostachys (Klotzsch) Baill., Étude Euphorb.: 365. 1858. TYPE: Podostachys subfloccosa Didr., designated by Wheeler [1975: 537]. [=C. lundianus (Didr.) Müll. Arg.].

Croton sect. Octolobium Chodat \& Hassl., Bull. Herb. Boissier ser. 2, 5: 496. 1905. TYPE: C. guaraniticus Chodat \& Hassl. [= C. aberrans Müll. Arg.].

Heterocroton S. Moore, Trans. Linn. Soc. London, Bot., ser. 2, 4: 461. 1895. Croton subg. Heterocroton (S. Moore) Pax in Engler \& Prantl, Nat. Pflanzenfam. Nachtr. 1: 211. 1897. TYPE: Heterocroton mentiens S. Moore $[\equiv C$. mentiens (S. Moore) Pax, $=$ C. sclerocalyx (Didr.) Müll. Arg.].

Shrubs; inflorescences with a distinct gap between staminate and pistillate portions, or with contracted inflorescences where the gap is not visible; sepals of pistillate flowers (5)6-8, equal; styles either bifid ( $C$. aberrans, $C$. brevipes, $C$. lundianus, $C$. sipaliwinensis, and $C$. trinitatis), tetrafid, or multifid, with $(6-) 12(-48)$ terminal branch tips. Clade $\mathrm{C}$ in Figs. 3 $\& 4$.

Included species (17): $\boldsymbol{C}$. aberrans Müll. Arg., C. araracuarae, $\boldsymbol{C}$. brevipes Pax, C. cerroazulensis $\mathrm{P}$. E. Berry \& Galdames, C. chiribiquetensis Cardiel, C. grossedentatus Pittier, C. hadrianii Baill., C. huamaliensis Riina, C. krukoffianus Croizat, C. lundianus (Didr.) Müll. Arg., C. macrodontus Müll. Arg., C. odontadenius Müll. Arg., C. sclerocalyx (Didr.) Müll. Arg., C. sincorensis Mart., $C$. sipaliwinensis Lanj., $C$. spiraeifolius Jablonski, $\boldsymbol{C}$. trinitatis Millsp.

Alphabetical List of the Species of Croton section Geiseleria (A. Gray) Baill.

1. Croton abaitensis Baill., Adansonia 4: 337. 1864. Oxydectes abaitensis (Baill.) Kuntze, Revis. Gen. Pl. 2: 610. 1891. TYPE: Brazil. Minas Gerais: Abaité, 1844, H. A. Weddell 1818 (holotype, P-623674!; isotypes, A47215!, F-V0056098F!).

Croton longinervius Müll. Arg., Fl. Bras. 11(2): 215. 1873. Croton longinervius var. major Müll. Arg., Fl. Bras. 11(2): 215. 1873, nom. inval. Oxydectes longinervia (Müll. Arg.) Kuntze, Revis. Gen. P1. 2: 613. 1891. 
TYPE: Brazil. Goiás: Serra de Christaës, s. d., J. B. E. Pohl 826 (lectotype, designated by Sodré et al. [2017: 9], W-51292!; isolectotype, G-434553!).

Croton longinervius var. minor Müll. Arg., Fl. Bras. 11(2): 216. 1873. TYPE: Brazil. Goiás: ad Rio S. Marcos prope S. Luzia, s. d., J.B. E. Pohl 1637 (lectotype, designated by Sodré et al. [2017: 9], W-51293!; isolectotypes, A-257952!, G-434554!, K-186104!, K-252628!, W-51294!).

Croton megaponticus Müll. Arg., Fl. Bras. 11(2): 210. 1873. Oxydectes megapontica (Müll. Arg.) Kuntze, Revis. Gen. Pl. 2: 613. 1891. TYPE: Brazil. Goiás: prope Megaponte, s. d., J. B. E. Pohl 1110 (lectotype, designated by Sodré et al. [2017: 9], W-4076!; isolectotypes, G-434616!, F-24501!).

Croton decarianus Pilger ex Glaziou, Mém. Soc. Bot. France 59(3): 620.

1913, nom. nud.

Distribution. Brazil (Distrito Federal, Goiás, Mato Grosso, Mato Grosso do Sul, Minas Gerais, Tocantins).

Notes. Croton abaitensis is placed in C. subsect. Geiseleria, due to its position in Clade A in Fig. 3 and its unequal pistillate sepals and bifid styles.

2. Croton aberrans Müll. Arg., Fl. Bras. 11(2): 232. 1873. Oxydectes aberrans (Müll. Arg.) Kuntze, Revis. Gen. Pl. 2: 613. 1891. TYPE: Brazil. Mato Grosso do Sul: in campis arenosis secus Rio Pardo, Sep. 1826, L. Riedel 546 (lectotype, designated by Sodré et al. [2019a: 28], LE-3045!; isolectotype, G-434413!).

Croton guaraniticus Chodat \& Hassl., Bull. Herb. Boissier II: 496. 1905. TYPE: Paraguay. Cordillera: Cordillera centralis; in region collium: Cerros de Tobaty, Sep. 1900, E. Hassler 6314 (lectotype, designated by Sodré et al. [2019a: 28], G-307062!; isolectotypes, A-47309!, B† [photo at F-0BN005109!], F-56134F!, G!, K-574182!, MPU-14831!, NY-246548!, P-623669!, P-623670!, S-07-12802, W).

Croton guaraniticus f. latifolius Chodat \& Hassl., Bull. Herb. Boissier II: 497. 1905. TYPE: Paraguay. Canindeyú: in campo Nandurucay Sierra de Maracayu, s. d., E. Hassler 4529 (lectotype, designated by Sodré et al. [2019a: 28], P-623671!; isolectotype, NY-246549!).

Croton guaraniticus var. virgatus Chodat \& Hassl., Bull. Herb. Boissier II: 497. 1905. TYPE: Paraguay. Canindeyú: Iter ad Yerbales montium Sierra de Maracayu, in regione vicine Igatimi, Dec. 1898-1899, E. Hassler 5604 (lectotype, designated by Sodré et al. [2019a: 28]. G-306908!; isolectotypes, G-306910!, G-306930!, G-306931!, GH-47310!, MPU14829 !, P-634499!).

Croton guaraniticus f. intermedia Chodat \& Hassl., Bull. Herb. Boissier II: 497. 1905. TYPE: Paraguay. Concepción: in campis siccis pr. Bellavista in regione cursus superioris fluminis Apa, Nov. 1901-1902, E. Hassler 7933 (lectotype, designated by Sodré et al. [2019a: 28], G-306934!; isolectotypes, G-306912!, G-306913!, G-306914!, G-306935!, MPU14830 !, P-623672!, P-623673!).

Croton guaraniticus f. microphylla Chodat \& Hassl., Bull. Herb. Boissier II: 497. 1905. TYPE: Paraguay. Concepción: in regione cursus superioris fluminis Apa, Nov. 1901-1902, E. Hassler 7933 b (lectotype, designated 
by Sodré et al. [2019a: 28], G-306911!; isolectotypes, G-306932!, G306933!).

Distribution. Argentina (Misiones), Bolivia (Santa Cruz), Brazil (Mato Grosso do Sul, Paraná, Rio Grande do Sul, Santa Catarina, São Paulo), Paraguay (Amambay, Canindeyú).

Notes. Croton aberrans is placed in C. subsect. Podostachys, due to its position in Clade $\mathrm{C}$ in Figs. 3 \& 4, and its equal pistillate sepals. Unlike many members of the subsection, it has bifid styles, and the inflorescences are very abbreviated, making it difficult to determine if they have a gap between the pistillate and staminate portions or not.

3. Croton adamantinus Müll. Arg., Fl. Bras. 11(2): 115. 1873. Oxydectes adamantina (Müll. Arg.) Kuntze, Revis. Gen. Pl. 2: 613. 1891. TYPE: Brazil. Minas Gerais: prope Jiquitinhonha in distr. Adamantium, Dec. 1824, L. Riedel 1252 (lectotype, designated by Sodré et al. [2019a: 29], LE-3049!; isolectotypes, G-434411!, K-185988!, LE-3046!, LE-3047!, LE-3048!, LE-3051!, LE-3052!).

Distribution. Brazil (Bahia, Ceará, Minas Gerais, Paraíba, Pernambuco, Piauí, Rio Grande do Norte, Sergipe).

Notes. Croton adamantinus is tentatively placed in $C$. subsect. Brasilienses, due to its equal pistillate sepals and bifid styles. It has not been sampled yet in molecular studies.

4. Croton adenodontus (Müll. Arg.) Müll. Arg., Fl. Bras. 11(2): 267. 1873. Croton glandulosus var. adenodontus Müll. Arg., Prodr. 15(2): 684. 1866. Oxydectes adenodonta (Müll. Arg.) Kuntze, Revis. Gen. Pl. 2: 613. 1891. TYPE: Brazil. Rio de Janeiro: no further locality, 5 Apr. 1831, L. Riedel 65 (lectotype, designated by Sodré et al. [2019a: 31], LE-3057!; isolectotypes, A-257929!, GH-257928!, K-254391!, LE-3055!, LE-3056!, LE-18229!, LE-18230!, NY-8435!, P 623667!).

Croton fluminensis (Kuntze) Schumann, Just's Bot. Jahresber. 348. 1900. Oxydectes fluminensis Kuntze, Revis. Gen. Pl. 3(3): 288. 1898. TYPE: Brazil. Rio de Janeiro: no further locality, Dec. 1892, O. Kuntze s.n. (lectotype, designated by Sodré et al. [2019a: 31], NY-503940!; isolectotypes, $\mathrm{B} \uparrow$ [photo F-0BN005096!], K-574180!). Janeiro).

Distribution. Brazil (Espírito Santo, Mato Grosso do Sul, Rio de

Notes. Croton adenodontus is placed in C. subsect. Geiseleria, due to its unequal pistillate sepals and bifid styles. It has not been sampled yet in molecular studies.

5. Croton agoensis Baill., Adansonia 4: 348. 1864. Oxydectes agoensis (Baill.) Kuntze, Rev. Gen. Pl. 2: 610. 1891. TYPE: Brazil. Minas Gerais: Brazilia Meridionalis, prope Olho d'Agua, 1816-1821, A. F. C. P. Saint- 
Hilaire s.n. (lectotype, designated by Sodré et al. [2019a: 32], P-623665!; isolectotypes, A-47218!, P-623664!).

Distribution. Brazil (Bahia, Goiás, Maranhão, Minas Gerais, Piauí, Tocantins).

Notes. Croton agoensis is placed in $C$. subsect. Brasilienses, due to its position in Clade B in Fig. 3 and its equal pistillate sepals and bifid styles.

6. Croton almadinensis Caruzo \& Riina, Ann. Missouri Bot. Gard. [this article, add volume and page \#]. TYPE: Brazil. Bahia: Serra do Corcovado, $9.8 \mathrm{~km}$ a SW de Coarci na estrada para Almadina, dai $\mathrm{N}$ ate Fazenda São José, 1442'21'’S, 39³6'12'”, 650-750 m, 21 Jun. 2005, $P$. Fiaschi, J. Paixao, L. C. Gomes, S. Sant'Ana et al. 2922 (holotype, CEPEC!; isotype, NY!).

\section{Distribution. Brazil (Bahia).}

Notes. Croton almadinensis is placed in $C$. subsect. Geiseleria, due to its position in Clade A in Figs. $3 \&$ 4, and its unequal pistillate sepals and bifid styles.

7. Croton amaraliae Riina \& P.E. Berry, Ann. Missouri Bot. Gard. [this article, add volume and page \#].TYPE: Brazil. Pará: Itaituba, estrada Santarém-Cuiabá BR 163, km 171, próximo a divisão Pará-MT, 9³5'S, 54³5’W, 22 Apr. 1983, I. L. Amaral, N. Silva, O. P. Monteiro, J. Lima, L. Brako, W. D. Reese \& M. Dibben 872 (holotype, INPA-112263!; isotypes, MO-3296892!, NY!, US-3336275!).

Distribution. Brazil (Amazonas, Mato Grosso, Pará, Rondônia).

Notes. Croton amaraliae is placed in C. subsect. Geiseleria, due to its position in Clade A in Figs. $3 \& 4$, and its unequal pistillate sepals and bifid styles.

8. Croton antisyphiliticus Mart. in Spix \& Mart., Reise Bras. 1: 282. 1823. Croton antisyphiliticus var. genuinus Müll. Arg., Prodr. 15: 593. 1866, nom. inval. Oxydectes antisyphilitica (Mart.) Kuntze, Revis. Gen. Pl. 2: 611. TYPE: Brazil. São Paulo: in campis editis e.g. ad Ypanema, ubi Erva Mular, 18 Jan. 1818, C. F. P. Martius s.n. (holotype, M-86128!; photo, F19474 !).

Croton perdicipes A. St.-Hil., Pl. Usuel. Bras. tab. 59. 1827. Croton antisyphiliticus var. perdicipes (A. St.-Hil.) Müll. Arg., Linnaea 34: 110. 1865. Croton perdicipes var. genuinus Baill., Adansonia 4: 337.1864 , nom. inval. TYPE: Brazil. Minas Gerais: campos au près de Tanque, comarca de Rio das Mortes, 1816-1821, A. F. C. P. Saint-Hilaire cat. C1, n. 227 (lectotype, designated by Sodré et al. [2019a: 32], P-623643!; isolectotypes, MPU-14855!, P-623644!).

Croton antisyphiliticus var. cordiifolius Müll. Arg., Linnaea 34: 110. 1865. Ocalia cordiifolia Klotzsch, Arch. Naturgesch. (Berlin) 7: 195. 1841, nom. 
nud. Ocalia grandifolia Klotzsch, Arch. Naturgesch. (Berlin) 7: 195. 1841, nom. nud. TYPE: Brazil. s. loc., s. d., F. Sellow s.n. (lectotype, designated by Sodré et al. [2019a: 32], BR-8763891!; isolectotypes, K-25436!, P556674!).

Croton antisyphiliticus var. latifolius (Baill.) Müll. Arg., Prodr. 15: 593. 1866. Croton perdicipes var. latifolius Baill., Adansonia 4: 337. 1864. TYPE:

Brazil. Minas Gerais: s. d., A. F. C. P. Saint-Hilaire cat. C2, n. $611^{8}$ (lectotype, designated by Sodré et al. [2019a: 32], P-556673!).

Croton antisyphiliticus var. minor (Baill.) Müll. Arg., Prodr. 15: 593. 1866. Croton perdicipes var. minor Baill., Adansonia 4: 337. 1864. Ocalia sellowiana Klotzsch (1841a: 195), nom. nud. TYPE: Brazil. Minas Gerais: s. loc., 1866, A. F. Regnell I 400 (lectotype, designated by Sodré et al. [2019a: 32], P-5566672!; isolectotype, LD [Cat. \# 1886282!], US109505 !).

Croton antisyphiliticus var. mollis Müll. Arg., Prodr. 15: 593. 1866. TYPE: Brazil. Minas Gerais: in editis campis S. de Grao Magor et versus Contagem de S. Maria in confin. Goyaz, s. d. [probably Jan. 1818], C. F. P. Martius s.n. (holotype, B†, lectotype, designated by Sodré et al. [2019a: 32], M-86130!; isolectotype, M-86129!).

Croton antisyphiliticus var. echiifolius Müll. Arg., Linnaea 34: 110. 1865. Ocalia echiifolia Klotzsch, Arch. Naturgesch. (Berlin) 7: 195. 1841, nom. nud. TYPE: Brazil. s. loc., 1858, H. A. Weddell 1086 (lectotype, here designated, G-DC [G-311951!]). Syntypes: Brazil. s. loc., 1834, P. W. Lund s.n. (G-311949!); s. loc., s. d., F. Sellow s.n. (not located); Minas Gerais: s. loc., s. d., A. F. Regnell s.n. (not located); Brazil, s. loc., 1840, P. Claussen $446(\mathrm{G})$.

Croton antisyphiliticus var. heterotrichus Müll. Arg., Fl. Bras. 11(2): 208. 1873. TYPE: Brazil. Minas Gerais: Villa de Uberaba, Oct. 1848, A. F. Regnell III 1086 (lectotype, designated by Sodré et al. [2019a: 33], BR8763235 !).

Croton antisyphiliticus var. hypoleucus Müll. Arg., Fl. Bras. 11(2): 207. 1873. TYPE: Brazil. Minas Gerais: ad S. Luzia in glareosis, et prope Barbacena, Oct. 1824, L. Riedel s.n. (lectotype, designated by Sodré et al. [2019a: 33], LE-18215!; isolectotype, LE-18214!).

Croton antisyphiliticus var. intermedius Müll. Arg., Fl. Bras. 11(2): 208. 1873. TYPE: Brazil. Minas Gerais: prope Barbacena, s. d., J. B. E. Pohl 1632 (catalogue number 3917) (lectotype, designated by Sodré et al. [2019a: 33], W-60075!; isolectotype, K-254361!).

Croton antisyphiliticus var. minutulus Müll. Arg., Fl. Bras. 11(2): 209. 1873. TYPE: Brazil. Minas Gerais: inter Tejuco seu Cidade Diamantina et Rio Paranahyba, s. d., W. Burchell 5891 (holotype, BR-8763563!).

Croton antisyphiliticus var. nitidulus Müll. Arg., Fl. Bras. 11(2): 209. 1873. TYPE: Brazil. Minas Gerais: ad Congonhas do Campo, 1844, M. D. Stephan s.n. (lectotype, designated by Sodré et al. [2019a: 33], BR8762573 !).

Distribution. Bolivia, Brazil (Distrito Federal, Goiás, Mato Grosso, Mato Grosso do Sul, Minas Gerais, Paraná, Santa Catarina, São Paulo), Paraguay. 
Notes. Croton antisyphiliticus is the type of $C$. subsect. Ocalia. It is recovered within Clade D in Figs. $3 \& 4$, and it has equal pistillate sepals and bifid styles.

9. Croton araracuarae J. Murillo, P.E. Berry \& M.V. Arbeláez, Novon 10: 64. 2002. TYPE: Colombia. Amazonas: Puerto Santander, afloramiento rocoso de Ciudad Perdida, 15 Aug. 1998, J. Murillo, A. Alfonso \& J. Madiego 1973 (holotype, COL-2070!; isotypes, COAH!, COL-2071!, MO!, NY-804220!).

Distribution. Colombia (Amazonas, Caquetá).

Notes. Croton araracuarae is placed in C. subsect. Podostachys, due to its equal pistillate sepals, multifid styles, and marked gap between the pistillate and staminate portions. It has not been sampled yet in molecular studies.

10. Croton arenosus Carn.-Torres \& Cordeiro, Brittonia 63: 123. 2011. TYPE: Brazil. Bahia: Reserva Biológica Esquentada, 956'58"S, 38 58'48"W, 440 m, 18 Feb. 2004, E. B. Miranda, R. M. Harley, F. H. Silva, B. M. da Silva \& Carlos 613 (holotype, HUEFS-2805!).

Distribution. Brazil (Bahia).

Notes. Croton arenosus is placed in C. subsect. Geiseleria, due to its position in Clade A in Figs. $3 \&$ 4, and its unequal pistillate sepals and bifid styles.

11. Croton asperrimus Benth., Hooker's J. Bot. Kew Gard. Misc. 376. 1854. Oxydectes asperrima (Benth.) Kuntze, Revis. Gen. Pl. 2: 611. 1891.

TYPE: Brazil. Pará: in vicinibus Obidos, Nov.-Dec. 1849, R. Spruce 478* (lectotype, designated by Sodré et al. [2019a: 36], K-1181152!; isolectotypes, K-1181155!, P-623631!).

Distribution. Bolivia (Santa Cruz), Brazil (Amazonas, Maranhão, Mato Grosso, Pará, Rondônia), Peru (Madre de Dios).

Notes: This species was formerly known only from the more northern part of its range in Amazonas, Maranhão, Pará, and Rondônia states in Brazil, but we have now identified specimens from farther south and west, in Mato Grosso state, as well as in eastern Bolivia and Peru. These include Berg et al. P19837 (INPA, MICH, NY), from Rio Aripuana, Mato Grosso; Fuentes 2132 (MO, NY, USZ), from Parque Nacional Noel Kempff Mercado in Santa Cruz, Bolivia; and Aguilar \& Castro 687 (WIS, USM), from Santuario Nacional Pampas del Heath, in Madre de Dios, Peru.

Croton asperrimus is placed in $C$. subsect. Ocalia, due to its position in Clade D in Figs. $3 \&$ 4, closely related to C. triangularis (within ITS). It has equal pistillate sepals and bifid styles. 
12. Croton betulinus Vahl, Symb. Bot. 2: 98. 1791. Oxydectes betulina (Vahl) Kuntze, Revis. Gen. P1. 2: 611. 1891. TYPE: U.S. Virgin Islands: St.

Thomas, no collector cited, probably M. Vahl (holotype, C-10011158!). Aldinia glechomoides Raf., Autik. Bot.: 50. 1840. TYPE: [not designated].

Distribution. Greater Antilles: British Virgin Islands, Cuba, Dominican Republic, Haiti, U.S.A. (Puerto Rico, Virgin Islands).

Notes. Croton betulinus is placed in C. subsect. Ocalia, due to its position in Clade A in Figs. 3 \& 4. It has equal pistillate sepals and bifid styles. Webster's (1993) concept of $C$. sect. Ocalia, equivalent to what we treat here as $C$. subsect. Ocalia, was that it had multifid styles, and in contradiction to that he still included $C$. betulinus within it.

13. Croton bidentatus Müll. Arg., Linnaea 34: 140. 1865. Oxydectes bidentata (Müll. Arg.) Kuntze, Revis. Gen. Pl. 2: 611. 1891. TYPE: Brazil, Rio de Janeiro: Sep. 1822, H. K. Beyrich s.n. (holotype, B†; lectotype, designated by Sodré et al. [2019a: 37], P-623619!).

Distribution. Brazil (Espírito Santo, Rio de Janeiro).

Notes. Croton bidentatus is placed in $C$. subsect. Geiseleria, due to its unequal pistillate sepals and bifid styles. It has not been sampled yet in molecular studies.

14. Croton brevipes Pax, Bot. Jahrb. Syst. 33: 290. 1903. TYPE: Costa Rica: bords du Rio del Convento, bassin du Diquis, 200 m, 26 Mar. 1898, $H$. Pittier 12117 (holotype, B†; lectotype, designated here, BR-6994198!; isolectotypes, CR, US-1014158!).

Distribution. Colombia (Chocó), Costa Rica (Alajuela, Guanacaste, Heredia, Puntarenas), Mexico (Veracruz), Nicaragua (Río San Juan), Panama (Colón, Panamá).

Notes. We report here a new record of $C$. brevipes for Mexico, based on $T$. Wendt et al. 3687 (F, MO) from southern Veracruz state near the borders of Oaxaca and Chiapas states. Croton brevipes is recovered sister to $C$. macrodontus in our ITS phylogenetic results (Fig. 3), corroborating the observation by Webster and Huft (1988) that the two are "extremely close."

Croton brevipes is placed in $C$. subsect. Podostachys, due to its position in Clade $C$ in Figs. $3 \& 4$. It has nearly equal pistillate sepals. Although Pax (1903) described the styles as bifid, other treatments, such as Burger and Huft (1995) list them as twice bifid, which is more consistent with its placement within $C$. subsect. Podostachys.

15. Croton campinarensis Secco, A. Rosario \& P. E. Berry, Phytotaxa 49: 2. 2012: TYPE: Brazil. Pará: Acará, campina do Guajará, Alça Viária, 20 Nov. 2009, R. S. Secco \& A. S. Rosário PEA 928 (holotype, MG-205681!; isotypes, $\mathrm{K}$ !, $\mathrm{MICH}$ !, NY!, RB!, SP!). 


\section{Distribution. Brazil (Pará, Piauí).}

Notes. Sodré et al. (2019a) listed this species as occurring in Venezuela, based on the collection of L. Williams 13250 (F, US-01243761) from Caicara, Estado Bolívar. However, we have redetermined this specimen as $C$. grossedentatus, which now leaves $C$. campinarensis as being endemic to Brazil.

Croton campinarensis is placed in $C$. subsect. Brasilienses, due to its equal pistillate sepals and overall morphological similarity to C. nepetifolius, as well as for its position in the molecular phylogenies in Figs. 3 and 4. It is unusual in that subsection for having tetrafid stigmas.

16. Croton carandaitensis Croizat, Darwiniana 6: 460. 1944. TYPE:

Paraguay. Chaco [currently Department Chuquisaca, Bolivia]: Carandaity [Carandaití], Mar. 1935, T. Rojas 7189 (holotype, A-47262!; isotype, AS).

\section{Distribution. Bolivia (Chuquisaca, Santa Cruz).}

Notes: Carandaití was part of a disputed area between Paraguay and Bolivia when the type specimen was collected, but the area is now part of Departamento Chuquisaca, Bolivia. This species in known only from the type (Rojas 7189) and a paratype (Steinbach 1793). Along with the type sheet at A there is a series of three sketches that Croizat made of a pistillate flower, an individual pistillate sepal, and an ovary with styles. These show a few small glands at the base of the pistillate pedicel and at the lower edge of the free part of the sepals, which could suggest an affinity with $C$. sect. Barhamia. Other features, though, appear to place it better in $C$. sect. Geiseleria and include acropetiolar glands; pistillate sepals that are obovate and partially fused at the base, later leaving a bowl-shaped receptacle after the capsule has dehisced; and filiform staminate bracts.

Croton carandaitensis is tentatively placed in C. subsect. Geiseleria, based on its bifid styles and general similarity to C. glandulosus. It has not been sampled yet in molecular studies.

17. Croton carinatus Müll. Arg., Linnaea 34: 126. 1865. Oxydectes carinata (Müll. Arg.) Kuntze, Revis. Gen. P1. 2: 611. 1891. TYPE: Brazil. Tocantins: Dianópolis, Serra do Duro, September 1839, G. Gardner 3438 (lectotype, designated by Sodré et al. [2019a: 39], BR-8764232!; isolectotypes, $\mathrm{B} \uparrow$ [photo at F-0BN005065!], E-346718!, F-56112F!, GDC-312238!, K-186098!, OXF-91584!, K-186099!, P-623084!, P623085 !).

\section{Distribution. Brazil (Tocantins).}

Notes. Croton carinatus is placed in C. subsect. Brasilienses, due to its equal pistillate sepals, bifid styles, and narrowly lanceolate leaves like some other members of the subsection. It has not been sampled yet in molecular studies. 
18. Croton catariae Baill., Adansonia 4: 349. 1864. TYPE: Brazil. Mato Grosso, 1833, C. Gaudichaud-Beaupré 247 (holotype, P-00623092!; isotypes, A-47263!; photo, RB-663842!).

Croton chaetocalyx Müll. Arg., Linnaea 34: 133. 1865. Oxydectes chaetocalyx (Müll. Arg.) Kuntze, Revis. Gen. P1. 2: 611. 1891. TYPE: Brazil. Megaponte, Villa Boa, 1837 or 1839, J. B. E. Pohl 1626 (holotype, B†; lectotype, designated by Sodré et al. [2017: 18], BR-8764560!; isolectotypes, A-63009!, F!, G-434439!, K-186109!, W-51197!, W$51198 !)$.

Distribution. Bolivia (Santa Cruz), Brazil (Bahia, Distrito Federal, Goiás, Maranhão, Mato Grosso, Mato Grosso do Sul, Minas Gerais, Pará, Tocantins), Suriname).

Notes. This species was placed by Van Ee et al. (2011) in $C$. sect. Barhamia, based on the equal pistillate sepals and the extensive glands typical of that section on the stipules, bracts, and pistillate calyces. However, it also has multiple pairs of basilaminar glands and bifid styles, both characters lacking in other species of $C$. sect. Barhamia but present in $C$. sect. Geiseleria. Therefore, we follow Sodré et al. (2019a) in placing this species here, but recommend it be pursued for molecular sequencing to confirm its sectional placement.

Croton catariae is assigned to $C$. subsect. Brasilienses, due to its equal pistillate sepals and bifid styles, as well as the glandular pistillate calyx that is present in some other members of this subsection. It has not been sampled yet in molecular studies.

19. Croton cerroazulensis P. E. Berry \& Galdames, Webbia 68: 17. 2013. TYPE: Panama: Panamá, Cerro Jefe, Finca Lindio, 750 m, 9 Jun. 1971, G. Webster, G. Breckon, M. Correa \& R. Dressler 16477 (holotype, PMA!; isotypes, DAV!, DUKE!, MO!, US!).

Distribution. Panama (Panamá).

Notes. Croton cerroazulensis is assigned to C. subsect. Podostachys, based on its equal pistillate sepals and tetrafid styles, as well as the inflorescence with a gap between the pistillate and the staminate portions. It has not yet been sampled in molecular studies. We hypothesize that it is phylogenetically related to C. brevipes and C. macrodontus. Webster \& Huft (1988) included specimens now assigned to C. cerroazulensis under $C$. brevipes, as pointed out by Berry \& Galdames (2013).

20. Croton chamelensis E. J. Lott, Brittonia 39: 309. 1987. TYPE: Mexico. Jalisco: Mpio. La Huerta, Estación de Biología Chamela, antiguo camino a Nacastillo, 17 Jul. 1976, L. A. Pérez J. 1391 (holotype, MEXU-553601!; isotypes, CAS-2147!, DAV!, TEX-371632!, US-345191!).

Distribution. Mexico (Guerrero, Jalisco, Nayarit). 
Notes. Croton chamelensis is placed in C. subsect. Geiseleria, due to its position in Clade A in Figs. 3 \& 4, part of the C. suavis complex, and its unequal pistillate sepals and bifid styles.

21. Croton chiribiquetensis Cardiel, Rev. Acad. Colomb. Ci. Exact. 71: 471. 1993. TYPE: Colombia. Caquetá: Sierra de Chiribiquete, Campamento Norte al límite SW de la meseta, $1^{\circ} 7^{\prime} \mathrm{N}, 72^{\circ} 50^{\prime \prime} \mathrm{W}, 500-550 \mathrm{~m}, 8$ Dec.1990, S. Castroviejo, J. M. Cardiel, G. Galeano \& F. Gonzalez 12009 (holotype, COL-2077!; isotypes, COL-2074!, COL-2075!, COL-2076!, MA-509697!, MA-509697-2!).

Distribution. Colombia (Caquetá).

Notes. Croton chiribiquetensis is assigned to C. subsect. Podostachys, based on its equal pistillate sepals and tetrafid styles, as well as the inflorescence with a gap between the pistillate and the staminate portions. It has not yet been sampled in molecular studies.

22. Croton crustulifer Croizat, Darwiniana 6: 451. 1944. TYPE: Brazil. Minas Gerais or Rio de Janeiro: Serra da Mantiqueira, 1882, A. F. M. Glaziou 14254 (holotype, A-47277!; isotypes, K-574178!, P-4831116!, P4831126!, US-67939!).

Distribution. Brazil (Minas Gerais, Rio de Janeiro).

Notes. Croton crustulifer is placed in C. subsect. Brasilienses, due to its equal pistillate sepals and bifid styles. It has not been sampled yet in molecular studies.

23. Croton cuadrosii P. E. Berry, Ann. Missouri Bot. Gard. [this article, add volume and page \#]. TYPE: Colombia. Bolívar: Município Santa Rosa de Simití [currently Município Santa Rosa del Sur], Inspección Los Canelos [currently Corregimiento Los Canelos], 700 m, 25 May 1986, H. Cuadros 2643 (holotype, MO!; isotypes, F!, JBGP!).

\section{Distribution. Colombia (Bolívar).}

Notes. Croton cuadrosii is tentatively placed in C. subsect. Ocalia, because it has subequal pistillate sepals and tetrafid styles, with no apparent gap between the staminate and pistillate portions. It has not yet been sampled in molecular studies, but it would be highly desirable to obtain sequence data, since it is morphologically so distinctive (see discussion above) that it could conceivably belong to a novel clade or subsection.

24. Croton cupulifer McVaugh, Brittonia 13: 163.1961 [as C. cupuliferus]. TYPE: Mexico. Colima: $14 \mathrm{mi} W N W$ of Santiago, along the road to Cihuatlán, Jalisco, 50 m, 7 Nov. 1960, R. McVaugh, C. Feddema \& R. W. Pippen 20771 (holotype, MICH-1104786!; isotypes, DAV!, G-434417!, NY-246457!, TEX-371637!, US-109540!. 
Distribution. Mexico (Colima, Jalisco).

Notes. Croton cupulifer is placed in C. subsect. Geiseleria, due to its position in Clade A in Fig. 3, part of a small Mexican clade along with $C$. martinianus and $C$. varelae, as well as for its strongly unequal pistillate sepals and bifid styles.

25. Croton curculiospermus Riina, Ann. Missouri Bot. Gard. [this article, add volume and page \#]. TYPE: Bolivia. Cochabamba: Prov. Mizque, $5 \mathrm{~km}$ de Pasorapa; sobre el camino a Pasorapillo, $18^{\circ} 18.19^{\prime} \mathrm{S}, 64^{\circ} 38.20^{\prime} \mathrm{W}, 2153$ m, 21 Feb. 2003, J.R.I. Wood \& M. Mendoza 19161 (holotype, USZ!; isotypes, $\mathrm{K}$ !, LPB!).

\section{Distribution. Bolivia (Cochabamba).}

Notes. Croton curculiospermus is placed in C. subsect. Geiseleria, due to its position in Clade A in Fig. 3, part of a clade with C. grewioides, as well as for its unequal pistillate sepals; the number of style divisions is as yet unknown, but based on its membership in Clade A we hypothesize that it has bifid styles.

26. Croton desertorum Müll. Arg., Fl. Bras. 11(2): 265. 1873. Oxydectes desertorum (Müll. Arg.) Kuntze, Revis. Gen. P1. 2: 613. 1891. TYPE: Brazil. Minas Gerais: in deserto, s. d. [1818], C.F.P. von Martius s.n. (lectotype, designated by Sodré et al. [2017: 21], M 86104! [photo at FV006600]; isolectotype, G-434490!).

\section{Distribution. Brazil (Bahia, Minas Gerais).}

Notes. Croton desertorum is placed in C. subsect. Brasilienses, due to its equal pistillate sepals and bifid styles. It has not been sampled yet in molecular studies.

27. Croton flavoglandulosus Lundell, Phytologia 1: 403. 1940. TYPE:

Mexico. Tabasco: in savanna at Achotal near Balancán, 9-14 May 1939, E. Matuda 3043 (holotype, MICH-1191486!; isotypes, A-47099!, F-56030F!, LL-371638!, MEXU-78312, NY-246465!).

Distribution. Belize, Guatemala (Petén), Mexico (Campeche, Quintana Roo, Tabasco, Yucatán).

Notes. This taxon was published as 'Croton flavoglandulosus,' but some indices list it as 'Croton flaviglandulosus.' For many years the name $C$. flavoglandulosus languished in obscurity, although it was included as an accepted species in lists such as Steinmann (2002), Martínez Gordillo et al. (2002), and Villaseñor (2016), but the name has largely not been applied to specimens other than the type. The name Croton jutiapensis was misapplied to specimens of this species from southern Mexico, but we do not $\operatorname{consider} C$. jutiapensis to occur in Mexico. 
Croton flavoglandulosus is placed in $C$. subsect. Geiseleria, due to its position in Clade A in Fig. 3, part of the C. suavis complex, as well as because of its unequal pistillate sepals and bifid styles.

28. Croton glandulosus L., Syst. Nat., ed. 10. 1275. 1759. Oxydectes glandulosa (L.) Kuntze, Revis. Gen. Pl. 2: 614. 1891. Decarinium glandulosum (L.) Raf., Neogenyton 1. 1825. TYPE: Jamaica, s. loc., s. d., P. Browne s. $n$. (lectotype, designated by Fawcett \& Rendle [1920: 285], LINN-1140-7!; isolectotypes, S-09-18929, S-09-18941).

Croton scordioides Lam., Encycl. 2: 215. 1786. Croton glandulosus var. scordioides (Lam.) Müll. Arg., Prodr. 15: 685. 1866. TYPE: Brazil. Rio de Janeiro: des environs de Rio Janeiro, Jun. 1767, P. Commerson s.n. (holotype, P-LAM!; isotypes, A-277217!, P-623601!; P-JUSS-674059!).

Croton divaricatus Swartz, Prodr. 100. 1788. Croton glandulosus var. divaricatus (Sw.) Müll. Arg., Prodr. 15: 684. 1866. TYPE: India occidentalis, s. d., s. coll., s.n. (holotype, S-R-1305!).

Croton affinis Geiseler, Croton. Monogr.: 25. 1807. TYPE: U.S.A. Puerto Rico: H. West s.n. (lectotype, designated here, C-10011169!; possible isolectotype, C-10011170!).

Croton glandulosus var. gardneri Müll. Arg., Prodr. 15: 684. 1866. TYPE: Brazil. Prov. Piauhy et Goyaz, 1844, G. Gardner 3435 (lectotype, designated by Sodré et al. [2019a: 43], BR-8761965!; isolectotypes, F56126F!, G-DC-312839!, NY-2465441, NY-246545!, P-623602!, P6236031, P-623604!).

Croton glandulosus var. intermedius Müll. Arg., Prodr. 15: 684. 1866. TYPE: Brazil. Bahia: Muritiba, 1842, J. S. Blanchet 3656 (lectotype, designated by Sodré et al. [2019a: 43], G-DC-312838!; isolectotypes, G-60034!, LE18217 !).

Croton glandulosus var. subincanus Müll. Arg., Prodr. 15: 685. 1866. TYPE: Brazil. Pará: Santarém, Mar. 1850, R. Spruce s.n. (lectotype, designated by Sodré et al. [2019a: 44], G-312828!; isolectotype, TCD-7623).

Croton meissneri Müll. Arg., Prodr. 15: 665. 1866. TYPE: Mexico. Veracruz: Orizaba, 1855, F. J. Müller s.n. (holotype, NY-246480!; isotypes, A47343 [fragment ex G]!, G-DC-312465!).

Croton glandulosus var. occidentalis Müll. Arg., Fl. Bras. 11(2): 270. 1873. TYPE: Brazil. Brazilia occidentali, s. d., Tamberlik s.n. (lectotype, designated by Sodré et al. [2019a: 44],W-60012!; isolectotype, W60013 !).

Croton glandulosus var. warmingii Müll. Arg., Fl. Bras. 11(2): 269. 1873. TYPE: Brazil. Minas Gerais prope Lagoa Santa, s. d., J. E. B. Warming 1646 (holotype, $\mathrm{C}$ not seen; photo at F!).

Distribution. Argentina, Bolivia, Brazil, Caribbean (Cuba, Hispaniola, Jamaica, Puerto Rico, Virgin Islands), Costa Rica, Ecuador, El Salvador, French Guiana, Guatemala, Guyana, Honduras, Mexico, Nicaragua, Panama, Paraguay, Peru, Suriname, Uruguay, central and eastern U.S.A., Venezuela. Introduced in Africa, Australia, Hawaii, India, Malaysia, and possible elsewhere. 
Notes. Van Ee et al. (2009) and Van Ee \& Berry (2016) recognized five varieties of Croton glandulosus in a conspectus of the species in the continental United States. It is not clear, however, which additional varieties should be recognized outside of the U.S.A., such as C. glandulosus var. intermedius Müll. Arg. and others cited above in the species' synonymy. See also Figs. 2 and 3 for the discordant positions of Sant'Ana 1103 and 1136, which are discussed in the Results section as representing likely hybrids involving C. glandulosus and another species. Further study of this widespread complex is clearly warranted.

Croton glandulosus is the type of $C$. sect. Geiseleria and therefore of the nominal subsection as well. It has unequal pistillate sepals and bifid styles. In the analysis of ITS, four different varieties sampled emerged as a strongly supported clade in Clade A of Fig. 3, sister to a small Mexican clade of morphologically similar species, while two Brazilian samples (Sant'Ana 1106 and 1131) were recovered sister to $C$. hostmannii. In contrast, in the trnL-F analysis (Fig. 4), the North American specimens of C. glandulosus were recovered sister to the Mexican clade, and the Caribbean C. glandulosus var. glabratus was recovered sister to the Sant'Ana specimens from Brazil.

\section{8a. Croton glandulosus L. var. glandulosus}

Distribution. Cuba, Hispaniola, Jamaica, Puerto Rico, likely elsewhere in the Caribbean, possibly Central and South America, but the overall distribution of this variety is uncertain at this time, pending further revision of the complex. Van Ee \& Berry (2016) did not consider the typical variety to be present in the continental United States.

28b. Croton glandulosus var. arenicola (Small) B. W. Van Ee, P. E. Berry, \& Ginzbarg, Harvard Pap. Bot. 14: 49. 2009. Croton arenicola Small, Bull. New York Bot. Gard. 3: 428. 1905. TYPE: U.S.A. Florida: Miami-Dade Co., pinelands between Cutler and Black Point, Nov. 1903, J. K. Small \& J. J. Carter 822 (holotype, NY-246420!; isotype, PH-8867!).

Croton betulinus sensu A. M. Ferguson, Rep. (Annual) Missouri Bot. Gard. 12: 48. 1901, non Vahl, Symb. Bot. 2: 98. 1791.

Distribution. U.S.A. Endemic to southern Florida, in Miami-Dade, Monroe, and Palm Beach counties.

28c. Croton glandulosus var. floridanus (A. M. Ferguson) R. W. Long, Rhodora 72: 22. 1970. Croton floridanus A. M. Ferguson, Rep. (Annual) Missouri Bot. Gard. 12: 50. 1901. TYPE: U.S.A. Florida: Lee Co., Gasparilla Key, July [no year given, prior to 1897], A. H. Curtiss 2523* (lectotype, designated by Van Ee et at. [2009: 50], F-307814!; isolectotypes, A-47056!, F-111203!, GH-47055!, MICH!, MO!, NY8384!, NY-232601!, NY-232603!, US-86027!).

Distribution. U.S.A., endemic to Broward, Collier, Lee, and Martin counties in southern Florida and Polk County in central Florida. 
28d. Croton glandulosus var. glabratus Urb., Symb. Antill. 1: 336. 1899. TYPE: U.S.A. Puerto Rico: prope Fajardo, 16 Apr. 1885, P. E. E. Sintenis 925 (lectotype, designated here, GH-47184!; isolectotype: US-656597!). Syntypes: U.S.A. Puerto Rico: prope Bayamon in litoralibus ad Cataño, $P$. E. E. Sintenis 1064 (US); prope Manatí in pascuis ad lagunam Tortuguero, P. E. E. Sintenis 6552 (US).

Distribution. U.S.A. (Puerto Rico).

Notes. Plants of Croton glandulosus var. glabratus key out to $C$. glandulosus var. septentrionalis Müll. Arg in the key of Van Ee \& Berry (2016), but they differ from it in being nearly glabrous. Both C. glandulosus var. glandulosus and C. glandulosus var. glabratus are present on Puerto Rico. Since Sintenis 925 was found in both GH and US, we selected that number and the sheet at $\mathrm{GH}$ as the lectotype.

28e. Croton glandulosus var. lindheimeri Müll. Arg. in A. P. de Candolle, Prodr. 15(2): 685. 1866. Croton glandulosus var. croftiae A. M. Ferguson in J. K. Small, Fl. S.E. U.S.: 696. 1903, nom. superfl. \& illeg. TYPE: U.S.A. Texas: F. J. Lindheimer Fasc. IV No. 691 (holotype, G [not seen]; isotypes, A-62527!, GH-47063!, GH-47061!, GH-47062!, MO-210962!, NY-232606!, US-69124!).

Croton glandulosus var. parviseminus Croizat, J. Arnold Arbor. 26: 188.

1945. TYPE: U.S.A. Texas: F. J. Lindheimer Fasc. IV No. $691 b$ (holotype, GH-267775!; isotypes: A-61788!, MO-1905112!, MO-211070!, MO211071!, MO-211072!, US-72354!).

Distribution. Northeastern Mexico and in the U.S.A. from Texas to southern Kansas. This variety was initially reported only from Mexico and Texas, however Van Ee et al. (2009) cited some specimens from as far north as southern Kansas.

28f. Croton glandulosus var. pubentissimus Croizat, J. Arnold Arbor. 26: 188. 1945. TYPE: U.S.A. Texas: Kleberg Co., Padre Island (10 miles SW of Mustang Island), 17 Nov. 1940, V. L. Cory s.n. (holotype, A-47064!).

Croton glandulosus var. hirsutus Shinners, Field \& Lab. 19: 183. 1951.

TYPE: U.S.A. Texas: Aransas Co., 6.5 open woods, 2 Jul. 1948, V. L. Cory 54597 (holotype, BRIT- 23498 [ex SMU]!; isotype, LL-371639!).

Distribution. U.S.A. Endemic to the Texas Gulf Coast counties of Aransas, Brazoria, Kenedy, Kleberg, Nueces, and San Patricio and a single collection from the more inland Colorado County.

28g. Croton glandulosus var. septentrionalis Müll. Arg. in A. P. de Candolle, Prodr. 15(2): 686. 1866. TYPE: U.S.A. Arkansas: Pulaski Co., Little Rock, 1835, G. Engelmann 6 (lectotype, designated by Croizat [1945: 188], M211058!; isolectotypes, MO-211057!, MO-211056!).

Croton glandulosus var. angustifolius Müll. Arg. in A.P. de Candolle, Prodr. 15(2): 686. 1866. TYPE: U.S.A. Texas: Harris Co., dry woods, Houston, May-Jun. 1842, F. J. Lindheimer Fasc. I No. 172 (lectotype, designated 
by Van Ee et al. [2009: 53], GH-47066!; isolectotypes, A-267803!, GH267802!, MO-211069!, MO-211076!).

Croton glandulosus var. crenatifolius A.M. Ferguson, Rep. (Annual) Missouri Bot. Gard. 12: 52. 1901. TYPE: U.S.A. Florida: Lee Co., San Carlos Bay, 5 Dec. 1891, J. H. Simpson 391 (lectotype, designated by Van Ee et al. [2009: 53], GH-61793!; isolectotypes: NY-232605!, US-935998!).

Croton glandulosus var. simpsonii A.M. Ferguson, Rep. (Annual) Missouri Bot. Gard. 12: 51. 1901. TYPE: U.S.A. Florida: Dade Co., Cocoanut Grove, 17 Mar. 1892, J. H. Simpson 533 (holotype, MO [not seen]; isotypes, GH-267801!, NY-1043427!, US-85385!).

Croton glandulosus var. shortii A.M. Ferguson, Rep. (Annual) Missouri Bot. Gard. 12: 50. 1901. TYPE: U.S.A. Kentucky: 1850, C. W. Short s.n. (holotype: MO-260063!; isotype, A-47067!).

Distribution. Mexico and U.S.A. In Mexico, in the Gulf Coast states of Tamaulipas and Veracruz. In the U.S.A., in the eastern half of the country from Texas north to Minnesota, east to Pennsylvania, and south to Florida.

29. Croton glechomifolius Müll. Arg., Linnaea 34: 126. 1865. Oxydectes glechomifolia (Müll. Arg.) Kuntze, Revis. Gen. P1. 2: 611. 1891. TYPE: Brazil. Paraná: s. loc., 15 Nov. 1828, F. Sellow s.n. (holotype, B†, photo at F-249290!); NEOTYPE: Brazil. São Paulo: in campis graminosis ad furnas, Mar. 1826, L. Riedel 263 (LE-18218, designated by Sodré et al. [2019a: 45].

Croton tragifolius Baill., Adansonia 6: 16. 1865. TYPE: Brazil. São Paulo: "bords du chemin, près le rio Verde", 1816-1821, A. F. C. P. Saint-Hilaire cat. C2 1387 (lectotype, designated by Sodré et al. [2019a: 45], P-493389!; isolectotype, P-493390!).

Distribution. Argentina (Misiones), Brazil (Paraná, Rio Grande do Sul, Santa Catarina, São Paulo), Paraguay (Amambay).

Notes. The concept of C. glechomifolius in Sodré et al. (2019a) is that of a species with bifid styles and subequal pistillate sepals, which would place it morphologically in C. subsect. Geiseleria. Webster (1993) placed $C$. glechomifolius in $C$. sect. Ocalia, which in his concept consisted of species with mainly multifid styles. We recovered Ginzbarg 687 (SP), identified as $C$. glechomifolius, in Clade D of Fig. 3, sister to Ginzbarg 688 (UPCB), which is identified as $C$. verbenifolius, and both of these are sister to C. asperrimus. For this reason, we place $C$. glechomifolius in $C$. subsect. Ocalia, but these species require further study and sampling.

30. Croton goyazensis Müll. Arg., Linnaea 34: 120. 1865. Oxydectes goyazensis (Müll. Arg.) Kuntze, Revis. Gen. P1. 2: 611. 1891. TYPE: Brazil. Goiás: in campis petrosis Catalão, Aug. 1834, L. Riedel 2473 (lectotype, designated by Sodré et al. [2017: 26], LE-3114!; isolectotypes, $\mathrm{B} \uparrow$ (photo, F-0BN005103!), G-434536!, G-DC-312494!, GH-47305!, K186100!, LE-3111!, LE-3112!, LE-3113!).

Croton luzianus Müll. Arg., Fl. Bras. 11(2): 218. 1873. Oxydectes luziana (Müll. Arg.) Kuntze, Revis. Gen. Pl. 2: 613. 1891. TYPE: Brazil. Goiás: 
ad Ponto Alto prope S. Luzia, s. d., J. B. E. Pohl 1618 (catalogue number 1034) (lectotype, designated by Sodré et al. [2017: 26], W-51288!; isolectotypes, F-V0056157!, G-434543!, W-51287!).

Croton goyazensis var. rotundifolius Glaz., Mém. Soc. Bot. France 3: 619.

1913, nom inval.

\section{Distribution. Brazil (Distrito Federal, Goiás, Minas Gerais).}

Notes. Reiterating what was discussed by Sodré et al. (2019a: 47), $C$. goyazensis was previously treated as occurring in several states of Brazil in addition to the ones we list here, as well as in Paraguay and Bolivia, but these reports were due to misidentifications, some of those in Brazil corresponding to what is now recognized as C. parodianus or C. seccoi. Croton goyazensis is unique in the section in its short, squat acropetiolar glands (olive-shaped) with a terminal pore (unlike the more typical trumpet-shaped glands of most species in the section), and in its recurved pistillate pedicels in fruit.

Croton goyazensis is placed in $C$. subsect. Geiseleria, due to its placement in Clade A in Figs. 3 \& 4. This is consistent with its bifid styles, but not by its equal pistillate sepals.

31. Croton gracilescens Müll. Arg., Linnaea 34: 110. 1865. Oxydectes gracilescens (Müll. Arg.) Kuntze, Revis. Gen. Pl. 2: 611. 1891. TYPE: Brazil. Goiás: prope Cavalcante, s. d., J. B. E. Pohl 297 (holotype, B100242753!, photo at F-0BN005104!; isotypes, A-257930!, BR-8762627!, G-DC-434535!, K-254364!; K-254366!).

Croton antisyphiliticus var. angustifolius Müll. Arg., Linnaea 34: 110. 1865. Ocalia angustifolia Klotzsch, Arch. Naturgesch. 7(1): 195. 1841, nom. nud. TYPE: Brazil. "Brazilia Meridionali", s. d., F. Sellow s.n. (B†).

Croton antisyphiliticus var. weddellianus (Baill.) Müll. Arg., Prodr. 15: 593.

1866. Croton perdicipes var. weddellianus Baill., Adansonia 4: 337. 1864. TYPE: Brazil. Goiás: Mara Rosa, Sertão d'Amaroleite, Sep.-Oct. 1844, H. A. Weddell 2753 (lectotype, designated by Sodré et al. [2019a: 45], P5566744!; isolectotype, P-5566743!).

Distribution. Brazil (Goiás, Mato Grosso, Tocantins).

Notes. Croton gracilescens is placed in C. subsect. Ocalia, due to its position in Clade D in Fig. 3, sister to several accessions of $C$. antisyphiliticus, confirming the close relationship and morphological similarities between these two taxa, and for its equal pistillate sepals and bifid styles.

32. Croton gracilirameus M. J. Silva, Sodré \& P. E. Berry, Syst. Bot. 40: 162. 2015. TYPE: Brazil. Goiás: Alto Paraíso de Goiás, Parque Nacional da Chapada dos Veadeiros, $3 \mathrm{~km}$ a oeste do Morro do Buracão, 14 $4^{\circ} 33.6^{\prime \prime} \mathrm{S}$, 47043'32.7"W, 1181 m, 10 Feb. 2013, M. J. Silva et al. 4716 (holotype, UFG-60363; isotype, MICH!).

Distribution. Brazil (Goiás). 
Notes. Croton gracilirameus is placed here in C. subsect. Brasilienses, due to its bifid styles and equal pistillate sepals with stipitate glandular trichomes along the margins. It has not been sampled yet in molecular studies.

33. Croton grewioides Baill., Adansonia 4: 365. 1864. Croton glycosmeus Müll. Arg., Linnaea 34: 140. 1865, nom illeg. Oxydectes grewioides (Baill.) Kuntze, Revis. Gen. Pl. 2: 610. 1891. TYPE: Brazil. Bahia: Marais de Japira, 1840, J. S. Blanchet 3100 (lectotype, designated by Sodré et al. [2019a: 49], P-00623585!; isolectotypes, A-257931!, A-257932!, BR8768223!, C-10011172!, F-56131F!, F-56132F!, G-312861, G-00434532!, G-DC-434533!, K-254381!, K-254382!, K-254383!, LE-3110!, MO260056!, NY-246546!, OXF-91947!, P-623583!, P-623584!, TUB-9091).

Croton zehntneri Pax \& Hoffmann, Repert. Spec. November. Regni Veg. 19: 1923. TYPE: Brazil. Bahia: Lapa, Caatinga da Mulata, Apr. 1912, L. Zehntner 4084 (holotype, M-89093!, photo at F-209696[6621]!).

Distribution. Bolivia (Chuquisaca, Santa Cruz), Brazil (Alagoas, Bahia, Ceará, Minas Gerais, Paraíba, Pernambuco, Piauí, Rio Grande do Norte, Sergipe), Peru (Amazonas).

Notes. This species has a very characteristic smell of cloves when the leaves are crushed (fresh or dry). There are some populations that smell of anise instead of cloves (Carneiro-Torres, pers. comm.), but they cannot be distinguished morphologically. It would be of interest to study this character further to determine if two different taxa are involved. This is a new report of C. grewioides for Peru, based on three collections from Amazonas Dept. (Campos 2130, MICH, MO; Campos 3653, MO; and Riina \& Campos 1470, $\mathrm{MICH})$.

Croton grewioides is placed in $C$. subsect. Geiseleria, due to its position in Clade A in Figs. 3 \& 4. It has bifid styles, but the pistillate sepals are equal in size and shape, which is at odds with most other members of the subsection.

34. Croton grossedentatus Pittier, J. Wash. Acad. Sci. 20: 8. 1930. TYPE: Venezuela: Lara, entre El Tocuyo y Humocaro Bajo, 6 Jan.1925, H. Pittier 13105 (holotype, US-109570!; isotypes, A-47308!, A-257933!, NY246547 !).

Distribution. Venezuela (Bolívar, Lara, Monagas, Sucre).

Notes. Sodré et al. (2019a) treated L. Williams 13250 (F, US01243761), from Caicara, Estado Bolívar, Venezuela, as belonging to $C$. campinarensis, but we think it corresponds more closely to C. grossedentatus, which now considerably expands the distribution of that species in Venezuela.

Croton grossedentatus is placed in $C$. subsect. Podostachys, due to its position in Clade $\mathrm{C}$ in Fig. 3, sister to $C$. sipaliwinensis, as well as for its equal pistillate sepals and tetrafid styles. It lacks the distinctive gap between the staminate and pistillate portions of the inflorescence that is characteristic of most species of $C$. subsect. Podostachys, but like $C$. aberrans, $C$. hadrianii, and $C$. odontadenius, it has very compact inflorescences. 
35. Croton hadrianii Baill., Adansonia 4: 313. 1864. TYPE: Brazil, s. loc., 1783-1792, A. R. Ferreira s.n. (comm. Étienne Geoffroy Saint-Hilaire) (lectotype, designated by Sodré \& Silva [2018a: 142], P-623573!; isolectotype, P-623574!, photo at F-1039147!).

\section{Distribution. Brazil (Mato Grosso, Pará, Rondônia).}

Notes. Croton hadrianii is placed in C. subsect. Podostachys, due to its position in Clade C in Figs. 3 \& 4, as well as for its (sub)equal pistillate sepals and tetrafid styles. Although the inflorescences are only $2-5 \mathrm{~cm}$ long, Sodré \& Silva (2018a) state that there is a short sterile zone between pistillate and staminate portions.

36. Croton harleyi Carn.-Torres \& Cordeiro, Brittonia 63: 128. 2011. TYPE: Brazil. Bahia: Rio de Contas, Serra do Rio de Contas, 134' $16^{\prime \prime} \mathrm{S}$, $41^{\circ} 35^{\prime} 50^{\prime \prime} \mathrm{W}, 5$ Dec. 2004, R. M. Harley et al. 55288 (holotype, HUEFS2836 !; isotypes, SP!, HUESB).

Distribution. Brazil (Bahia, Pernambuco, Piauí, Rio Grande do Norte).

Notes. Carneiro-Torres et al. (2011) described the pistillate sepals of $C$. harleyi as being unequal, however their illustration of it depicts sepals that could be considered equal or at the most subequal. Sodré et al. (2019a) considered the pistillate sepals of $C$. harleyi to be equal, and they considered it to be most closely related to $C$. arenosus, a member of $C$. subsect. Geiseleria. The inflorescences of $C$. harleyi lack the gap between pistillate and staminate flowers characteristic of $C$. subsect. Podostachys, but they are only 1-2 cm long. Other species with similar short, compact inflorescences, such as $C$. aberrans, $C$. grossedentatus, $C$. hadrianii, and $C$. odontadenius are placed in $C$. subsect. Podostachys. Morphologically, $C$. harleyi is compatible with any of the four subsections, and it lacks any characteristics that would clearly place it in one over the others. Given the balance of evidence, we hypothesize that it belongs in $C$. subsect. Geiseleria, but it has not been sampled yet in molecular studies and that is clearly desirable.

37. Croton hirtus L'Hér., Stirp. Nov. 17. 1785. Podostachys hirta (L'Hér.) Klotzsch, Arch. Naturgesch. (Berlin) 7: 194. 1841. Brachystachys hirta Klotzsch, London J. Bot. 2: 47. 1843. Croton glandulosus var. hirtus (L’Hér.) Müll. Arg., Prodr. 15: 684. 1866. Oxydectes glandulosa var. hirta (L'Hér.) Kuntze, Revis. Gen. P1. 2: 614. 1891. Croton glandulosus subsp. hirtus (L'Hér.) Croizat, Bull. Torrey Bot. Club 75: 401 1948. TYPE: French Guiana. s. loc., s. d., L. C. Richard s.n. (holotype, P-623551!; isotype, P-623550!).

Croton glandulosus var. tenellus Müll. Arg., Prodr. 15: 685. 1866. TYPE: Venezuela. s. loc., s. d., A. Fendler $1236 \beta$ (holotype, G-312827!).

Croton glandulosus var. sagotii Müll. Arg., Fl. Bras. 11(2): 269. 1873. TYPE: French Guiana. Karouany, 1857, P. A. Sagot 503 (lectotype, designated by Sodré et al. [2019a: 54], BR-8762085; isolectotypes, G-312852!, S-R10503!). 
Croton glandulosus var. martii Müll. Arg., Fl. Bras. 11(2): 268. 1873. TYPE: Brazil. Maranhão: in campis et pascuis ad flumen Itapicurú prope Caxias, s. d. [May-Jul. 1819], C. F. P. Martius 2557a (lectotype, designated by Sodré et al. [2019a: 54], M-89077!; isolectotypes, K-254389!, L-234460, M-89078!, M-89079!).

Croton glandulosus var. schomburgkianus Müll. Arg., Fl. Bras. 11(2): 268. 1873. TYPE: Guyana. s. loc., 1836, R. H. Schomburgk 101 (lectotype, designated by Sodré et al. [2019a: 55], BM-1125625!; isolectotypes, BM1124406!; F-56127F!, G-312849!).

Croton glandulosus var. sieberi Müll. Arg., Fl. Bras. 11(2): 268. 1873. TYPE: Trinidad and Tobago. in insula Trinitatis, s. d., Sieber Fl. Trinit. 106 (lectotype, designated by Sodré et al. [2019a: 55], L-234397; isolectotypes, L-234398, G-312850!).

Croton glandulosus var. cordovensis Müll. Arg., J. Bot. 12: 203. 1874. TYPE: Argentina. prope Cordoba, 1870, P. G. Lorentz 294 (lectotype, designated by Sodré et al. [2019a: 55], G-378337!; isolectotypes, B†, CORD-3076).

Croton comes Standl. \& L.O. Williams, Ceiba 1: 148. 1950, syn. nov. TYPE: Honduras. Dept. Morazán, camino entre El Zamorano y Chaguite, $800 \mathrm{~m}$, 1 Aug. 1949, P. C. Standley 22056 (holotype, F!; isotypes, EAP-112262, US-109525!).

Distribution. Widespread and weedy, from Mexico to Argentina, adventive in some Old World countries. In the New World in Argentina, Belize, Bolivia, Brazil, Caribbean (Jamaica, Dominica, Trinidad \& Tobago), Colombia, Costa Rica, Ecuador, El Salvador, French Guiana, Guatemala, Guyana, Honduras, Mexico, Nicaragua, Panama, Paraguay, Peru, Suriname, Uruguay?, and Venezuela. Introduced in the Old World at least in Guinea, Ivory Coast, Liberia, Sierra Leone, Tanzania, India, Irian Jaya, Papua New Guinea, and Java (these last according to Radcliffe-Smith (1978: 235).

Notes. Croton hirtus is placed in C. subsect. Geiseleria due to its unequal pistillate sepals and bifid styles. All accessions of the species sequenced for ITS and trnL-F emerge together in a clade within Clade A (Figs. $3 \& 4$ ).

38. Croton hostmannii Miq., Linnaea 21: 477. 1848. Oxydectes hostmannii (Miq.) Kuntze, Revis. Gen. Pl. 2: 610. 1891. TYPE: Suriname, 1843, F. W. R. Hostmann 1106 (holotype, K-574187, ex Herb. Hooker!; isotypes, A63011 !, B [†, photo at F-0BN005120!, F-56144 ex W!, G-434525!, G-DC312276 !, K-574186 [ex Herb. Bentham]!, P-623538!, P-623539!, S-R10529, U-1885!, W-4051!, W-Rchb.-1889-67196!).

Croton subincanus Müll. Arg., Linnaea 34. 139. 1865, syn. nov. Type. Guyana. Roraima, 1842-1843, R. H. Schomburgk 665 (lectotype, designated by Sodré et al. [2019a: 88], G-434675!; isolectotypes, BM560063!, G-DC-312864!, G-434676!, K-254414!, P-634733!, P-634734!).

Croton galeopsifolius Lanj., Recueil Trav. Bot. Néerl. 31: 455. 1934. TYPE: Guyana: Potaro River, 27 Feb. 1879, E. F. im Thurn s.n. (holotype, K574181 !). 
Distribution. Brazil (Roraima), French Guiana, Guyana, Suriname, Venezuela (Amazonas, Bolívar, Táchira).

Notes. Secco (2008) and Sodré et al. (2019a) incorrectly cited the specimen at $\mathrm{U}$ as the holotype of $C$. hostmannii. However, the protologue mentioned a single specimen, "Hostm. 1106 ex Hb. Hook.", so therefore it is the specimen at $\mathrm{K}$ from the former Hooker Herbarium that is treated here as the holotype. Croton hostmannii was listed as possibly occurring in Maranhão state of Brazil by Secco (2008), and then this was accepted by Sodré et al. (2019a). Both reports were based on the collection of L. Carreira 2702 (MG), from Município de Santa Quitéria, cerrado, Fazenda Bom Jesus, Maranhão state. Upon re-examining this specimen, we determined that it actually corresponds to the recently described $C$. seccoi, which was recorded as occurring in the same cerrado region of Maranhão state.

There appears to be considerable variability in leaf size in specimens of $C$. hostmannii, with the type having particularly smaller leaves and the type of $C$. galeopsifolius having much larger leaves. Likewise, we did not find any consistent differences between $C$. hostmannii and $C$. subincanus, as suggested by Sodré et al. (2019a).

We have now added Estado Táchira, an Andean state in Venezuela adjoining Colombia, to the distribution of C. hostmannii. This is based on four specimens we have determined at FT, initially identified as $C$. subincanus: Bono 4223, Bono 5023, Bono 5125, and Bono 7773; all come from the vicinity of San Cristóbal, between 800-1000 m. This unusual disjunction between the Andes and the Guayana Shield is not new and is known from other groups, such as Bonnetia paniculata Spruce \& Benth. and Caraipa (Aymard \& Campbell 2008).

Croton hostmannii is placed in C. subsect. Geiseleria given that all accessions of it are recovered within Clade A of Figs. 2 and 3, and because of the unequal pistillate sepals and bifid styles.

39. Croton huamaliensis Riina, Ann. Missouri Bot. Gard. [this article, add volume and page \#]. TYPE: Peru. Huánuco: Prov. Huamalias, Maquizapa (carretera Monzón), 700 m, 18 Feb. 1966, J. Schunke-Vigo 1098 (holotype, NY!; isotypes, AMES, DAV-89230!, DAV-105887!, F!, MA!, MICH!, NY!).

\section{Distribution. Peru (Huánuco).}

Notes. Croton huamaliensis is placed in C. subsect. Podostachys, due to its position in Clade $\mathrm{C}$ in Fig. 3, sister to C. brevipes and C. macrodontus, as well as for its subequal pistillate sepals and styles with ca. 12 terminal tips. It is not clear from the single known collection if there is a gap between the pistillate and the staminate portions (some of the inflorescences are quite short), but this would be expected if it is indeed a member of $C$. subsect. Podostachys and if it is related to $C$. brevipes. There are some members of $C$. subsect. Podostachys, such as $C$. aberrans, $C$. grossedentatus, and $C$. hadrianii, that have very short inflorescences in which the gap between the pistillate and staminate portions is not evident. 
40. Croton inaequilobus Steyerm., Los Angeles County Mus. Contr. Sci. 21: 7. 1958. TYPE: Brazil. Goiás: Chapada dos Veadeiros, $14 \mathrm{~km}$ South of Veadeiros, in sandstone rocky area on west bank of stream and above, 4730'S, 14²0'W, 25 Apr. 1956, E. Y. Dawson 14685 (holotype, R104977!; isotypes, F-V0056145F!, RSA-2666!).

\section{Distribution. Brazil (Goiás).}

Notes. Croton inaequilobus is placed in $C$. subsect. Geiseleria due to the unequal pistillate sepals and bifid styles. It has not been sampled yet in molecular studies.

41. Croton itzaeus Lundell, Phytologia 1: 405. 1940. TYPE: Mexico: Yucatán, Progreso, 23 Jul. 1938, C. L. Lundell \& A. A. Lundell 8046 (holotype, MICH-1191485!; isotypes, A!, BRIT-23502, CAS-2143, DUKE-10000389F, F-56037F!, F-56038F!, LL-371641, MEXU-711151, NY-246469!, S-S-G-1728, US-109587!, WIS-v0227301WIS!).

\section{Distribution. Mexico (Yucatán).}

Notes. Croton itzaeus is placed in C. subsect. Geiseleria due to its placement in Clade A of Figs. $3 \& 4$, as part of the $C$. suavis complex. It also has unequal pistillate sepals and bifid styles.

42. Croton junceus Baill., Adansonia 4: 339. 1864. Oxydectes juncea (Baill.) Kuntze, Revis. Gen. P1. 2: 612. 1891. TYPE: Brazil. Mato Grosso: entre Goyas et Cujaba, Nov.-Dec. 1844, H. A. Weddell 2940 (lectotype, designated by Sodré et al. [2019a: 60], P-623522!).

Distribution. Brazil (Goiás, Mato Grosso, Mato Grosso do Sul).

Notes. Croton junceus is placed in $C$. subsect. Brasilienses due to the equal pistillate sepals and bifid styles. It shares very narrow leaves with $C$. carinatus, and the two are presumably closely related, although neither has yet been sampled in molecular studies.

43. Croton jutiapensis Croizat, Publ. Field Mus. Nat. Hist. Bot. Ser. 22: 450. 1942. TYPE: Guatemala: Dept. Jutiapa, vicinity of Jutiapa, alt. ca. 850 m, Oct.-Nov. 1940, P. Standley 74971 (holotype, A-47109!; isotype, F93629F!).

Croton ceanothifolius Standl. \& L.O. Williams, Ceiba 3: 117. 1952, nom. illeg., non Baillon [1864]. Croton nicaraguensis Radcl.-Sm. \& Govaerts, Kew Bull. 52: 188. 1997. TYPE: Nicaragua: Dept. Chontales, cerca de Juticalpa, 160 m, 4-13 Jun. 1947, P. C. Standley 9287 (holotype, F!; isotype, EAP).

Croton pluvialis Standl. \& L.O. Williams, Ceiba 3: 119. 1952. TYPE:

Nicaragua: Dept. Jinotega, Cerro de la Cruz and vicinity, in sierra west of Jinotega, 1200-1400 m, 7 Jul. 1947, P. C. Standley 11034 (holotype, F56058F!; isotypes, EAP-105698, EAP-105699). 
Distribution. Costa Rica (Guanacaste), El Salvador, Guatemala (Jutiapa), Honduras, Nicaragua (Chontales, Estelí, Jinotega, León, Madriz, Managua, Matagalpa), Panama (Coclé).

Notes. Our concept of $C$. jutiapensis is that it ranges rather contiguously from Jutiapa Department in southern Guatemala to Guanacaste Province in northern Costa Rica, and then disjunctly to the dry lowlands of central Panama. The eastern and southernmost known population of this species is in Coclé, Panama, namely Lee 8072 (MICH) and Ruiz \& Ruiz 108 (PMA), and these two specimens represent a new record of the species for Panama. It is a morphologically variable species, and the five accessions of it that are included in the ITS phylogeny are recovered in three close, but different places in Clade A (Fig. 3), although without strong support for being distinct. All accessions of $C$. jutiapensis, C. lagunillae, C. ortholobus, $C$. ramillatus, and $C$. suavis included in the molecular analyses are recovered within a $C$. suavis complex with very little resolution among them (Figs. $3 \&$ 4). In addition to these five accepted species, there are a total of 13 synonymous taxa assignable to the $C$. suavis complex, which indicates how geographically widespread and morphologically variable this complex is. This is further highlighted by our earlier decision (Berry et al. 2007) to recognize C. guildingii subsp. tiarensis, whereas here we treat this taxon as a distinct species (C. lagunillae). Although the ITS data do not recover each of these five species as reciprocally monophyletic (Fig. 3), our decision on which species to recognize is based on morphological and ecological distinctions, and this results in each taxon being largely allopatric with respect to the rest.

Croton jutiapensis is placed in $C$. subsect. Geiseleria due to its placement in Clade A in Figs. $3 \& 4$, as part of the C. suavis complex, and for its unequal pistillate sepals and bifid styles.

44. Croton kallunkiae Riina \& Caruzo, Ann. Missouri Bot. Gard. [this article, add volume and page \#]. TYPE: Brazil. Espírito Santo: Piuma, roadside at base of Morro Agá, ca. $5 \mathrm{~km} \mathrm{~S}$ of Piuma on Rod. ES-60, 2052'S, 4046'W, 18 Jan. 1993, J. A. Kallunki \& J. R. Pirani 332 (holotype, SP!; isotypes, SPF!, MO!, NY!).

Distribution. Brazil (Bahia, Espírito Santo).

Notes. Croton kallunkiae is placed in C. subsect. Geiseleria due to its placement on Clade A in Figs. 3 \& 4, and for its unequal pistillate sepals and bifid styles.

45. Croton krukoffianus Croizat, Darwiniana 6: 453. 1944. TYPE: Brazil. Rondônia: near Tabajara, upper Machado River region, 1 Dec. 1931, B. A. Krukoff 1480 (holotype, A-47326!; isotypes, G-434571!, NY-233106!, P623521!, S-S07-12786, U-1886). Sodré et al. [2019a: 60] designated the NY sheet as lectotype, but they were apparently unaware that the designated holotype is at A.

Croton subserratus Jablonski, Mem. New York Bot. Gard. 12(3): 164. 1965. TYPE: Venezuela. Amazonas: Cerro Guanay, summit, 1800 m, 2 Feb. 
1951, B. Maguire, K. D. Phelps, C. B. Hitchcock \& G. Budowski 31731

(holotype, NY-688114!; isotypes, US-810679!, VEN-749581!).

Distribution. Brazil (Amazonas, Mato Grosso, Roraima, Rondônia), Venezuela (Amazonas).

Notes. Croton krukoffianus is placed in C. subsect. Podostachys due to its position in Clade $\mathrm{C}$ in Figs. 3 \& 4, and for its equal pistillate sepals, highly divided styles, and apparent gap between the pistillate and staminate portions. The type of $C$. subserratus is the only specimen of $C$. sect. Geiseleria so far known from the summit of one of the tepuis of the Guiana Shield, and it is unusual for its high elevation $(1800 \mathrm{~m})$, in comparison to the remaining lowland collections of C. krukoffianus.

46. Croton lagunillae Croizat, Mem. Soc. Cien. Nat. La Salle (Caracas) 10(26): 122. 1950. TYPE: Venezuela. Mérida: región xerófila en las inmediaciones de Lagunillas, 1949, G. Marcuzzi s.n. (holotype, CAR \# 837 !; isotype, $\mathrm{F}$ !).

Croton marcuzzianus Croizat, Mem. Soc. Cien. Nat. La Salle (Caracas) 10(26): 123. 1950. TYPE: Venezuela. Mérida: región xerófila en las inmediaciones de Lagunillas, 1949, G. Marcuzzi s.n. (holotype, CAR \#836!; isotype, $\mathrm{F}$ !).

Croton guildingii subsp. tiarensis P. E. Berry, Contr. Univ. Michigan Herb. 25: 172. 2007, syn. nov. TYPE: Venezuela: Aragua, Loma de Hierro, Km 15 antes de la mina de níquel, $10^{\circ} 80^{\prime} 50^{\prime \prime} \mathrm{N}, 63^{\circ} 55^{\prime \prime} \mathrm{W}, 1200 \mathrm{~m}, 1$ Aug. 2001, R. Riina, P. E. Berry \& C. Reyes 1274 (holotype, MICH!; isotypes, F, GH, NY, US, VEN!, WIS).

Distribution. Venezuela (Aragua, Mérida, Miranda).

Notes. The ITS and trnL-F phylogenies (Figs. $3 \& 4$ ) both recover the single accession of $C$. lagunillae within the accessions of $C$. chamelensis, $C$. ortholobus, C. ramillatus, C. suavis, and C. jutiapensis. Croton lagunillae can be distinguished from $C$. suavis by having smaller, more coriaceous leaves, a more strongly dichotomous branching pattern, more golden pubescence on the upper surface of the leaves, a shorter inflorescence, and being ecologically restricted to higher elevations on more 'stressed' soil types (serpentine outcrops with high nickel concentrations in Aragua/Miranda states and alkaline soils rich in sodium calcium carbonates in Mérida state).

Croton lagunillae is placed in $C$. subsect. Geiseleria due to its placement in Clade A of Figs. $3 \& 4$, as part of the C. suavis complex, and for its unequal pistillate sepals and bifid styles.

47. Croton lotorius Croizat, J. Arnold Arbor. 26: 185. 1945. TYPE:

Guatemala: Huehuetenango, between Santa Ana Huista and Rancho Lucas, Sierra de los Cuchumatanes, 800-900 m, 26 Aug. 1942, J. A. Steyermark 51332 (holotype, A-135124!; isotypes, F-56044F!, US109606!).

Distribution. Mexico (Chiapas), Guatemala (Huehuetenango). 
Notes. Croton lotorius is placed in C. subsect. Geiseleria due to its unequal pistillate sepals and bifid styles. It has not been sampled yet in molecular studies.

48. Croton lundianus (Didr.) Müll. Arg., Prodr. 15: 662. 1866. Podostachys lundianus Didr., Vidensk. Meddel. Naturhist. Foren. Kjøbenhavn 137. 1857. Croton lundianus var. genuinus Müll. Arg., Prodr. 15: 663. 1866, nom. inval. Croton glandulosus var. lundianus (Didr.) L.B. Sm. \& Downs, Fl. Ilustr. Catar. 1 (Euforbiac.): 90. 1988. TYPE: Brazil. São Paulo: Taubaté, Nov. 1833, P. W. Lund s.n. (holotype, C-10011178!).

Podostachys subfloccosa Didr., Vidensk. Meddel. Naturhist. Foren. Kjøbenhavn 135. 1857. Croton lundianus var. subfloccosus (Didr.) Müll. Arg., Prodr. 15: 663. 1866. TYPE: Brazil: São Paulo: Taubaté, s. d., P. W. Lund s.n. (lectotype, designated by Sodré et al. [2019a: 63], C-10011179!; isolectotype, C-10011180!).

Croton klotzschii Baill., Adansonia 4: 346. 1864. Podostachys incana Klotzsch, Arch. Naturgesch. (Berlin) 7: 194. 1841, nom. nud. Podostachys sellowiana Klotzsch, Arch. Naturgesch. (Berlin) 7: 194. 1841, nom. nud. Croton klotzschii var. incana Baill., Adansonia 4: 347. 1864, nom. nud. TYPE: Brazil. Brazilia meridionali, s. d., F. Sellow s.n. (lectotype, designated here, K-254394!; isolectotypes, BR-13317614!, K-254395!, P633410!). Syntype: Brazil. São Paulo: s. loc., 1816-1821, A. F. C. P. Saint-Hilaire cat. D 736 (P-55657433!, P-5565745!).

Croton klotzschii var. bahiensis Baill., Adansonia 4: 347. 1864. Croton lundianus var. bahiensis (Baill.) Müll. Arg., Prodr. 15: 663. 1866. TYPE: Brazil. Bahia: s. loc., Apr. 1834, J. S. Blanchet 1665 (lectotype, designated by Sodré et al. [2019a: 62], P-633411!; isolectotypes, A-257944!, A257945!, A-257946!, G-434544!, G-312475!, P-633412!).

Croton klotzschii var. hilarii Baill., Adansonia 4: 347. 1864. Croton lundianus var. hilarii (Baill.) Müll. Arg., Prodr. 15: 663. 1866. TYPE: Brazil. São Paulo: s. loc., 1816-1821, A. F. C. P. Saint-Hilaire cat C1 1116 (lectotype, designated by Sodré et al. [2019a: 62], P-5565739!; isolectotype, A2579471).

Croton klotzschii var. latifolius Baill., Adansonia 4: 347. 1864. Croton lundianus var. latifolius (Baill.) Müll. Arg., Prodr. 15: 663. 1866. TYPE: Brazil. Rio de Janeiro: s. loc., 1831-1833, C. Gaudichaud-Beaupré 1137 (lectotype, designated by Sodré et al. [2019a: 62], P-633407!; isolectotype, G-312476!).

Croton klotzschii var. microphylla Baill., Adansonia 4: 347. 1864. Croton lundianus var. microphyllus (Baill.) Müll. Arg., Prodr. 15: 664. 1866. TYPE: Brazil. São Paulo: s. loc., s. d., A. F. C. P. Saint-Hilaire 1115 (holotype, P-5565736!).

Croton teucridium Baill., Adansonia 4: 349. 1864. TYPE: Brazil. Espírito Santo: s. loc., 1816-1821, A. F. C. P. Saint-Hilaire cat. C2, $2^{e}$ part., 262-b (lectotype, designated by Sodré et al. [2019a: 62], P-634743!; isolectotypes, A-47452!, F-56208F!, P-634742!).

Croton similis Müll. Arg., Linnaea 34: 134. 1865. Croton lundianus var. similis (Müll. Arg.) Müll. Arg., Prodr. 15: 663. 1866. Podostachys incana Klotzsch, Arch. Naturgesch. (Berlin) 7: 194. 1841, nom. nud. Podostachys 
sellowiana Klotzsch, Arch. Naturgesch. (Berlin) 7: 194. 1841, nom. nud. Croton klotzschii var. incana Baill., Adansonia 4: 347. 1864, nom. nud. TYPE: Brazil. Brazilia meridionali, s. d., F. Sellow s.n. (holotype, B†; lectotype, designated by Sodré et al. [2019a: 62], K-254394!; isolectotypes, BR-13317614!, K-254395!, P-633410!).

Croton lundianus var. glabrescens Müll. Arg., Prodr. 15: 664. 1866. TYPE:

Brazil. Bahia: s. loc., 1834, J. S. Blanchet 1824 (lectotype, designated by Sodré et al. [2019a: 62], G-434547!).

Croton lundianus var. gracilentus Müll. Arg., Prodr. 15: 664. 1866. TYPE: Brazil. Ceará: s. loc., s. d., C. Kalkmann 141 (holotype, MEL!; isotype, G312466!).

Croton lundianus var. leptophyllus Müll. Arg., Prodr. 15: 664. 1866. TYPE: Brazil. Pernambuco: s. loc., Nov. 1837, G. Gardner 1129 (holotype, B†; lectotype, designated by Sodré et al. [2019a: 62], K-254405!; isolectotypes, G-434549!, K-254404!).

Croton lundianus var. major Müll. Arg., Prodr. 15: 663. 1866. TYPE: Brazil. s. loc., s. d., J. B. E. Pohl s.n. (holotype, B!).

Croton lundianus var. mollis Müll. Arg., Prodr. 15: 664. 1866. TYPE: Brazil. Espirito Santo: s. loc., s. d., M. A. zu Wied-Neuwied s.n. (holotype, B†; lectotype, designated by Sodré et al. [2019a: 62], M-86076!; isolectotype, G-434545!).

Croton lundianus var. pubescens Müll. Arg., Prodr. 15: 664. 1866. TYPE: Brazil. Minas Gerais: s. loc., s. d., C. F. P. Martius (holotype, B $\dagger$ ).

Croton lundianus var. serratus Müll. Arg., Prodr. 15: 664. 1866. Podostachys serrata Klotzsch, Arch. Naturgesch. (Berlin) 7: 194. 1841, nom. nud. Croton dentifolius Baill., Adansonia 4: 347. 1864, nom. nud. TYPE: Brazil. Bahia or Espírito Santo: s. loc., s. d., F. Sellow s.n. (lectotype, designated by Sodré et al. [2019a: 62], BR-8710857!; isolectotypes, P633409!, K-254396!).

Croton lundianus var. hirtus Müll. Arg., Fl. Bras. 11(2): 230. 1873. TYPE: Brazil. Brazilia meridionali, s. d., F. Sellow s.n. (lectotype, designated by Sodré et al. [2019a: 62], BR-8710833; isolectotypes, G-434551!, LE18219 !).

Croton lundianus var. intercedens Müll. Arg., Fl. Bras. 11(2): 229. 1873. TYPE: Brazil. São Paulo: s. loc, s. d., W. Burchell 3910 (lectotype, designated by Sodré et al. [2019a: 63], K-254400!; isolectotype, G434548!).

Croton lundianus var. psilophyllus Müll. Arg., Fl. Bras. 11(2): 229. 1873. TYPE: Brazil. Minas Gerais: Padre de Correia, Sumidouro et Ribeirão, s. d., J. B. E. Pohl 1611 (catalogue number 14) (holotype, W-60098!).

Croton lundianus var. rufidulus Müll. Arg., Fl. Bras. 11(2): 227. 1873. TYPE: Brazil. forte in prov. Goyaz, s. loc, s. d., J. B. E. Pohl s.n. (not found).

Croton yacaensis Croizat, Darwiniana 6: 459. 1944. TYPE: Paraguay. [Cordillera]: Alto valle del Rio Y-acá, prope Chololó, Dec. 1900, E. Hassler 6804 (holotype, A-47464!; isotypes, F-V0192148F!, G-307114!, G-307115!, G-307116!, P-634779!, P-634780!). Sodré et al. (2019a: 60) designated one of the $\mathrm{G}$ sheets as lectotype, but they were apparently unaware that the designated holotype is at A.

Distribution. Argentina (Corrientes), Brazil (from northeastern to 
southeastern states and inland to Tocantins, but not in Amazonian states), Paraguay (Cordillera).

Notes. Croton lundianus is the type of $C$. subsect. Podostachys. Eight accessions of the species are recovered together in Clade $\mathrm{C}$ in Fig. 3, sister to C. aberrans, and as part of a broader polytomy of species in Clade C in Fig. 4. It is also consistent with the subsection with its obvious gap between the pistillate and staminate portions of the inflorescence and 6 or 7 equal pistillate sepals. Unlike most members of the subsection, it has bifid styles.

49. Croton macrodontus Müll. Arg., Linnaea 34: 128. 1865. Oxydectes macrodonta (Müll. Arg.) Kuntze, Revis. Gen. P1. 2: 612. 1891. TYPE: Mexico. s. loc., erroneously attributed by Müller to José Pavón, but clearly a collection made by M. Sessé y Lacasta \& J. M. Mociño s.n. and later sold and distributed by Pavón [see McVaugh 1990: 22, 223] (holotype, G434541 [ex Herb. Boissier]!; isotype, G-DC-312497!).

Croton liebmannii Müll. Arg., 15(2): 665. 1866. TYPE: Mexico. Oaxaca, prope San Jago Amatlán, Jul. 1842, F. Liebmann s.n. (holotype, C (not found); isotype: G-DC-312464!).

Croton bisserratus Sessé \& Moc., Fl. Mexic., ed. 2: 222. 1894. TYPE:

Mexico. [Veracruz]: in montibus Cordovae, s. d., M. Sessé y Lacasta \& J. M. Mociño 4170 (lectotype, designated by Nelson [1997: 396], MA602087!; other original material, Mexico. [Veracruz]: in montibus Cordovae, M. Sessé y Lacasta \& J. M. Mociño 4162 (MA-602088!), 4171 (MA-602089!, MA-602090!).

\section{Distribution. Mexico (Puebla, Veracruz, Oaxaca).}

Notes. Croton macrodontus is placed in C. subsect. Podostachys due to the placement of two different accessions together in Clade $\mathrm{C}$ in Fig. 3, sister to $C$. brevipes, and for the gap between the pistillate and staminate portions of the inflorescence, the equal pistillate sepals, and the multifid styles. Müller Argoviensis (1865) described the styles of C. liebmannii as bifid, and from the limited material that we have examined, it appears that the species can vary from having bifid to tetrafid styles.

50. Croton macrosepalus Sodré \& M. J. Silva, Plant Syst. Evol. 305: 237. 2019. TYPE: Brazil. Tocantins: Dianópolis, Serra Geral do Tocantins, in the region where the source of the river Palmeiras is located, ca. $30 \mathrm{~km} \mathrm{E}$ to the urban area of Dianópolis, ca. $5 \mathrm{~km}$ after the bridge over the river

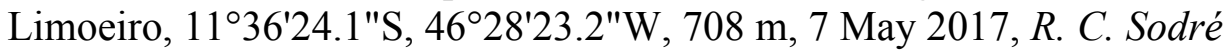
\& U. S. Amaral 3198 (holotype, UFG, not seen; isotypes, K, P, RB, SP, not seen).

Distribution. Brazil (Bahia, Goiás, Tocantins).

Notes. Croton macrosepalus is placed in C. subsect. Geiseleria due to its strongly unequal pistillate sepals and bifid styles. It is placed in Clade A in Fig. 4 (trnL-F), sister to C. spica, whereas in Fig. 3 (ITS), it emerges in an entirely different subclade of Clade A. As noted in the Results section, the 
sequences from C. macrosepalus and C. spica are from Sodré \& Silva (2019b), and it is possible that editing errors may have contributed to the long branches shown in Fig. 3. Morphologically, they have little in common to support their position as closely related species, although both are consistent with their placement in $C$. subsect. Geiseleria.

51. Croton magniglandulifer (V. W. Steinm.) B. W. Van Ee, comb. nov. [this article, add volume and page \#] Croton ramillatus var. magniglandulifer V. W. Steinm., Aliso 19: 184. 2001. TYPE: Mexico: Morelos, Mun. de Tlaquiltenango: Sierra de Huaxtla, ca. $1 \mathrm{~km}$ (by air) S of Huaxtla, 18 $23^{\prime} 46$ N, 9904'02" W, ca. 1100 m, 23 Sep. 1995, V. M. Steinmann, V. E. Ashworth, R. Cerros T., J. T. Columbus \& L. M. Zahn 798 (holotype, RSA-2674!; isotypes, ARIZ, DAV!, FCME, HUMO, IEB-162327, NY!).

\section{Distribution. Mexico (Guerrero, Morelos).}

Notes. Our molecular results (Figs. 3 \& 4) corroborate Steinmann's (2001) recognition of this taxon as distinct, but recover it closer to $C$. chamelensis than to C. ramillatus. Lott (1987) described Croton chamelensis as being most similar to $C$. ramillatus, which is also corroborated by the molecular results (Fig. 3). This species and Croton chamelensis are similar in the overall shape of their leaves and their long acropetiolar glands. Lott (1987) described and illustrated the partially fused rays of the stellate indumentum of C. chamelensis, which Steinmann (2001) referred to as "lepidote" in his key to the Mexican species of Croton sect. Geiseleria. Croton magniglandulifer lacks partially fused rays in the trichomes, which serves to distinguish it from $C$. chamelensis. Furthermore, it would appear that the two species do not occur sympatrically, with $C$. chamelensis known from Jalisco and Nayarit, $C$. magniglandulifer known from Guerrero and Morelos, and the putatively closely-related $C$. ortegae (see discussion under that species) known only from Sinaloa. All of these species belong to $C$. subsect. Geiseleria, due to their positions in Clade A in Figs. $3 \& 4$, in the C. suavis complex, and their unequal pistillate sepals and bifid styles.

52. Croton malvavisciifolius Millsp., Publ. Field Mus. Nat. Hist. Bot. Ser. 2: 419. 1916. TYPE: Mexico. Yucatán: Yot Tzonot, 16 Jul. 1916, G. F. Gaumer 1319 (holotype, F-56046F!; isotype, NY-246473!). Yucatán).

Distribution. Belize, Mexico (Campeche, Chiapas, Quintana Roo,

Notes. Croton malvavisciifolius is placed in C. subsect. Ocalia, due to its position in Clade D in Fig. 3, sister to several accessions of C. betulinus, and for its equal pistillate sepals and bifid styles. In Fig. 4, it is also part of Clade D, but part of a broader polytomy including C. betulinus, C. repens, and other species.

53. Croton martinianus V.W. Steinm., Novon 8: 81, 1998. TYPE: Mexico. Sonora: Mun. Álamos, Sierra de Álamos, along the trail from El Chalatón to La Huerta, $27^{\circ} 00^{\prime} \mathrm{N}, 108^{\circ} 58^{\prime} \mathrm{W}$, ca. $750 \mathrm{~m}, 31 \mathrm{Aug}$. 1996, V. W. 
Steinmann 952 (holotype, ARIZ; isotypes, BM-884378, DAV!, IBUG, IEB-224609, MEXU-1439553, MICH-1107995!, MO-176285!, NY232578!, RSA-2669!, USON).

Distribution. Mexico (Jalisco, Sinaloa, Sonora).

Notes. Croton martinianus is placed in $C$. subsect. Geiseleria due to its placement in Clade A of Figs. $3 \& 4$, as part of a clade with $C$. cupulifer and C. varelae that is closely related to $C$. glandulosus, and for its unequal pistillate sepals and bifid styles.

54. Croton mcvaughii G. L. Webster, Contr. Univ. Michigan Herb 23: 361. 2001. TYPE: Mexico. Jalisco: Mun. Cabo Corrientes, $5 \mathrm{~km} \mathrm{~N}$ of El Tuito, 16-17 Dec. 1970, R. McVaugh 25521 (holotype, MICH!).

Distribution. Mexico (Jalisco, Nayarit).

Notes. Croton mcvaughii is placed in C. subsect. Ocalia, due to its position in Clade D in Fig. 3, sister to several accessions of $C$. repens, and for its equal pistillate sepals and bifid styles.

55. Croton mollis Benth., Hooker's J. Bot. Kew Gard. Misc. 6: 375. 1854.

TYPE: Brazil. Amazonas: Manaus, Oct. 1851, R. Spruce 1806 (lectotype, designated by Sodré et al. [2019a: 67], K-254384!; isolectotypes, A47350!, B n. v., photo at F-0BN005135!, BR-8710871!, G-434609!, G434610!, G-312858!, GOET-3356, K-254385!, LD-1629579, LE-3129!, NY-262929!, OXF-91967!, P-634504!, P-634505!, TCD-7627).

Croton gardnerianus Baill., Adansonia 4: 301. 1864. TYPE: Brazil. Amazonas: Barcellos, on the Rio Negro, R. H. Schomburgk 944 (holotype, P-623194!; isotypes, A-257926 [fragm. ex P]!, BM-13717913!, BM- 13717914!, K-254417!, K-254418!, L-2203819!). Baillon's designation of the type as G. Gardner 944 from Ceará, Brazil, collected in Aug.-Nov. 1838, was due to an error in labeling (see discussion below), so it is here attributed to Schomburgk instead.

Croton crenatus Mull. Arg., Linnaea 34: 129. 1865. TYPE: Venezuela. “Ad Orinocum,” s.d. [1800], A. J. A. Bonpland \& F. W. H. A. von Humboldt s.n. (holotype, B-Willd 17866! [barcode B-W 17866-01 0], photo, F0BN005078!).

Croton wittianus Üle, Verh. Bot. Vereins Prov. Brandenburg 50: 75. 1908 [1909]. TYPE: Brazil. Amazonas: Manaus, am Strande bei Ouvidor, Jan. 1901, E. H. G. Ule 5330 (lectotype, designated by Sodré et al. [2019a: 67], HBG- 516405 not seen, photo at F-0BN005197!; isolectotypes, A47351!, B-100127735!).

Notes. Van Ee et al. (2011) included Croton mollis in Croton sect. Adenophylli, but this was corrected by Sodré et al. (2019a). The divergent dot on their distribution map of $C$. mollis on the coast of Ceará State in northeastern Brazil in figure 36b (Sodré et al., 2019a: 56) represents their interpretation of the type of $C$. gardnerianus, which they recognized as a 
synonym of $C$. mollis. We agree that $C$. gardnerianus corresponds to $C$. mollis, but it is highly unlikely that $C$. mollis occurs in Ceará, since there is nothing in that area that is similar to the particular habitat conditions where $C$. mollis occurs, namely sandy banks or outcrops along blackwater rivers and streams in Amazonian Brazil, Colombia, and Venezuela. There are several other collections identified as C. gardnerianus in speciesLink (http://splink.org.br), but these are incorrect identifications as far as we can tell from the photographs available there. According to Gardner's catalog of his plant collections in Brazil (Hind, 2012), which appeared to be arranged in roughly chronological numerical order, Gardner's collection number 944 came from Pernambuco State between October and December 1837. There is a specimen labeled Gardner 944 at BM that does come from that date and locality, but it corresponds to Galphimia brasiliensis (L.) Juss.

(Malpighiaceae). So it is puzzling how a specimen of Croton with the same collection number ended up at $\mathrm{P}$, with a label indicating it was collected in Ceará between August and November 1838.

We believe that we can now explain this discrepancy. The type specimen of Croton gardnerianus at P, the one appearing as Gardner 944 from Ceará, Brazil, is mislabeled. It is actually a duplicate of the Schomburgk 944 collections at Kew and elsewhere, from Amazonian Brazil (see type citation above). This eventually became apparent to us when we noticed that the small slips of paper that were used to field-label the plants by making two horizontal slits and slipping them onto the stems, both hand-labeled with the same number "944," were virtually identical on the Kew sheet of Schomburgk 944 from the former Hooker Herbarium at Kew (K-254418), one of the sheets at BM (BM-13717914), and the sheet labeled as Gardner 944 at Paris (P623194). When comparing the actual specimens, they very clearly came from the same plant. The sheet at P bears a printed label showing Gardner as the collector and coming from Ceará in August-November 1838, and at the bottom it states "Envois re us en janvier et abril 1840." The collection of Schomburgk 944 at K from the former Bentham Herbarium (K-254417) lists the collecting date as 1839, so it is possible that duplicates of both the Gardner and Schomburgk collections were distributed from Kew at the same time in early 1840 and subsequently mixed up by the time they were sorted at Paris. The collection numbers and locality data of the Schomburgk brothers from the Guianas are notoriously difficult to interpret, but only Robert Schomburgk had collected there in 1839, when he made an extensive trip across southern Venezuela, down the Rio Negro in Brazil and back up the Rio Branco to then British Guiana. Although both specimens of Schomburgk 944 at K mention only Guiana on the labels, Klotzsch (1845: 48) attributed them to Barcellos, on the Rio Negro in Brazil, which Robert Schomburgk visited in March of 1839 (Schomburgk, 1840: 259-260). Indeed, on the sheet of Schomburgk 944 we recently discovered at L, besides "Guiana anglica," the handwritten tag slipped onto the stem states, "Barcellos on the rio Negro," so this appears to confirm Klotzsch's statement. It is also possible that Klotzsch, who was at the Berlin Herbarium at the time, had received his own duplicate of Schomburgk 944 from Kew to assist Bentham with his series of identifications of the Schomburgk collections, and that specimen had the location information that he cited. If so, those collections at B were destroyed during the bombing of 
World War II, so we cannot confirm that supposition.

The concept of Croton mollis in Sodré et al. (2019a), in which they considered C. wittianus to be a synonym, is of a species with bifid or tetrafid styles and pistillate flowers with unequal sepals. The type of $C$. mollis and other specimens examined throughout the species' range have pistillate flowers with somewhat unequal sepals, bifid styles, and entire or subentire-margined leaves apparently without obvious marginal glands in herbarium material, though some glands were evident upon closer examination of one of the isotypes at $\mathrm{K}$ (M. Lujan, pers. comm.). Marginal nectary glands have been observed in the field in populations along the Rio Negro, near Manaus (Vitarelli, pers. comm.). In contrast, the type of $C$. wittianus has pistillate flowers with equal sepals and crenate-margined leaves with very evident stipitate marginal glands. Although the protologue of $C$. wittianus states that the styles are tetrafid, it appears to us that the pistillate flowers on the type specimens are bifid, rather than obviously tetrafid. Since the types of both $C$. mollis and $C$. wittianus come from the shores of the Rio Negro at Manaus, it is all the more reason to conclude that they represent the same species, as this area is well collected. The area where the type of $C$. wittianus was collected (Ponta do Ouvidor) is now part of the developed port of Manaus, where there is little or no native vegetation left. We place Croton mollis in Croton subsect.

Geiseleria due to its somewhat unequal sepals and bifid styles, as well as its placement in the molecular phylogenies in Figures 3 and 4.

56. Croton mucronifolius Müll. Arg., Fl. Bras. 11(2): 216. 1873. Oxydectes mucronifolia (Müll. Arg.) Kuntze, Revis. Gen. Pl. 2: 613. 1891. TYPE: Brazil, Piauí: s. loc., Aug.1839, G. Gardner 2722 (lectotype, designated by Sodré et al. [2019a: 67], G-434608!; isolectotypes, K-186101!, K-186102!, OXF-91966!, US-109619!).

Distribution. Brazil (Bahia, Goiás, Maranhão, Mato Grosso, Minas Gerais, Piauí, Tocantins).

Notes. Croton mucronifolius is designated as the type of $C$. subsect. Brasilienses. It belongs to Clade B in Fig. 3, sister to C. agoensis, and in Fig. 4 , sister to $C$. nepetifolius and C. campinarensis (C. agoensis is not sampled in Fig. 4). It has equal and glandular pistillate sepals, bifid styles, glandular teeth on the leaf margins, and five main veins at the base of the leaves.

57. Croton nepetifolius Baill., Adansonia 4: 344. 1864. Oxydectes nepetifolia (Baill.) Kuntze, Revis. Gen. P1. 2: 610. 1891. TYPE: Brazil. Minas Gerais: s. loc., 1816-1821, A. F. C. P. Saint-Hilaire cat B2 2115 (lectotype, designated by Sodré et al. [2019a: 69], P-634517!; isolectotype, P634518 !).

Croton roborensis Stand1., Publ. Field Mus. Nat. Hist. Bot. Ser. 22: 36.1940. TYPE: Bolivia: Dpto. Santa Cruz, Roboré de Chiquitos, 416 m, Oct. 1934, M. Cárdenas 2952 (holotype, F!; isotypes, GH, LIL-1835!). 
Distribution. Bolivia (Santa Cruz, Tarija), Brazil (Alagoas, Bahia, Ceará, Minas Gerais, Paraíba, Pernambuco, Piauí, Rio Grande do Norte, Sergipe).

Notes. There has been recent confusion over the circumscription of Croton nepetifolius, as evidenced by statements and illustrations in Sodré et al. (2019a). In their notes on the species, they implied that it has 4-fid styles, the same as C. campinarensis. In their line drawing of the pistillate flower (their figure $31 \mathrm{~N}$ ), the styles are shown as being 4-fid, based on Del'Arco \& Fernandes s.n. (TEPB-1359), from Caracol, Serra das Confusões, Piauí state. On the other hand, the image in their photographic plate (their figure 33D, with no voucher listed) clearly shows bifid styles. The protologue of $C$. nepetifolius states that the type has bifid styles, which is also the case for $C$. roborensis from Bolivia, which we are treating here as a synonym. Sodré et al. (2019a) challenged an earlier identification of $C$. nepetifolius from Venezuela, based on Williams 13250 (US, VEN), from Caicara, Estado Bolívar and which has 4-fid styles. They re-identified it as $C$. campinarensis, but we now recognize it as belonging instead to $C$. grossedentatus.

Croton nepetifolius is placed in $C$. subsect. Brasilienses due to the placement of two accessions in Clade B in Fig. 3, one of which is an isotype of C. roborensis, one accession in Clade B in Fig. 4, and for its equal pistillate sepals. However, further study is required to determine if the style branching is variable, or if there are different populations with bifid and tetrafid styles, or even if these represent distinct taxa.

58. Croton odontadenius Müll. Arg., Fl. Bras. 11(2): 227. 1873. Oxydectes odontadenia (Müll. Arg.) Kuntze, Revis. Gen. Pl. 2: 613. 1891. TYPE: Brazil. Minas Gerais: in campis aridis petrosis prope Lagoa Santa, 5 Oct. 1863, J. E. B. Warming 1642 (lectotype, designated by Sodré et al. [2017: 41], C-10011184!; isolectotype, G-434597!).

Croton caperoniifolius Müll. Arg., Fl. Bras. 11(2): 206. 1873. Oxydectes caperoniifolia (Müll. Arg.) Kuntze, Revis. Gen. Pl. 2: 613. 1891. TYPE: Brazil. Minas Gerais: Lagoa Santa, Rio das Velhas, 4 Nov. 1863, J. E. B. Warming 1572 (lectotype, designated by Caruzo \& Cordeiro [2007: 41], C-10011160!; isolectotype, G-434446!).

Croton sclerocalyx var. lanceolatus Müll. Arg., Linnaea 34: 135. 1865. TYPE: Brazil. Minas Gerais: s. loc., 1845, J. F. Widgren s.n. (holotype, S-R10551).

Distribution. Brazil (Distrito Federal, Goiás, Mato Grosso do Sul, Minas Gerais).

Notes. Croton odontadenius is placed in C. subsect. Podostachys, due to its numerous (6-8) equal pistillate sepals and multifid styles. The inflorescence is very short (1.8-3 cm long), so it is hard to determine if there is a gap between the pistillate and staminate portions. It has not yet been sampled in molecular studies.

59. Croton ortegae Standl., Publ. Field Mus. Nat. Hist. Bot. Ser. 22: 25.1940. TYPE: Mexico. Sinaloa: Mazatlán: Loma Atravesada, Sep. 1932, J. G. 
Ortega 7019 (holotype, F-0056051F!; isotypes, A-47120!, K-186026!, MEXU-17087, US-109633!).

\section{Distribution. Mexico (Sinaloa).}

Notes. This species is known from just two specimens: the type, which comes from what is now a military base surrounded by the city of Mazatlán, and Ferris \& Mexia 5222 (US), which is from north of Mazatlán. Both of these specimens have just pistillate flowers, and more work is required before concluding that the species is dioecious, as the protologue suggests. If sampled molecularly, we hypothesize that this species would be recovered close to $C$. chamelensis, based on their morphological similarity.

Croton ortegae is placed in C. subsect. Geiseleria due to its unequal pistillate sepals, bifid styles, and presumed close relationship to $C$. chamelensis.

60. Croton ortholobus Müll. Arg., Flora 55: 9. 1872. TYPE: "Guatemala" [in error for Costa Rica]. prope Cartago, 1841, E. R. von Friedrichsthal 1417 (holotype, W, sheet annotated by Müller as "spec. originalis"!; isotypes, FF0056052F!, G-DC-434593!, W).

Oxydectes costaricensis Kuntze, Revis. Gen. Pl. 2: 614. 1891. Croton costaricense Kuntze, Revis. Gen. Pl. 2: 614. 1891, nom. nud. TYPE: Costa Rica. Turrialba-Cartago, \pm 3000 ', 21 Jun. 1874, O. Kuntze 2237 (holotype, NY-272973!; isotypes, K-186019!, US!).

Croton costaricensis Pax ex Durand \& Pittier, Prim. Fl. Costaric. 2(5): 331332. 1900. TYPE: Costa Rica. au dessus de La Verbena près Alajuelita, 1000 m, Aug. 1894, A. Tonduz 8862 (lectotype, designated here, CR-8862; isolectotypes, G!, US-109532!).

\section{Distribution. Costa Rica (Cartago, Heredia).}

Notes. Although there are references to the publication of $C$. costaricensis Pax in the Anales Inst. Fís.-Geogr. Mus. Nac. Costa Rica 9: 196. 1896 or 1898 , this issue was never distributed and was not effectively published until 1906, so the 1900 publication takes precedence in the establishment of the name. The single accession of $C$. ortholobus in the molecular phylogenies (Figs. $3 \& 4$ ) emerges with accessions of $C$. ramillatus, C. jutiapensis, and C. suavis. Burger and Huft (1995) recognized $C$.

ortholobus as distinct from $C$. jutiapensis by its more restricted and higher elevation habitats in the central valley of Costa Rica (vs. C. jutiapensis, which is found at lower elevations in Guanacaste province), but further study is needed to determine whether these two species should be considered conspecific.

Croton ortholobus is placed in $C$. subsect. Geiseleria, due to its placement in Clade A in Figs. 3 \& 4, within the C. suavis complex, and for its unequal pistillate sepals and bifid styles.

61. Croton pachysepalus Griseb., Mem. Amer. Acad. Arts n. s. 8: 159. 1861. Oxydectes pachysepala (Müll. Arg.) Kuntze, Revis. Gen. Pl. 2: 612. 1891. TYPE: Cuba. [Santiago de Cuba]: in collibus prope [El] Cobre, 1856- 
1857, C. Wright 559 (holotype, GOET-003358; isotypes, A-277360 [just the packet]!, BR-6999261!, F-56096F [fragment]!, G-434620!, G-DC311740!, GH-47204!, GH-47205!, K-185951!, K-185952!, NY-83376!, P634618!, PH-25697!, PH-7349!, S-R-10552, YU-001361).

Distribution. Cuba (Santiago de Cuba), Haiti.

Notes. The sheet A-277360 contains a fragment packet labeled as $C$. Wright 559 coming from the Paris herbarium. The main specimen on the sheet is E. C. \& G. M. Leonard 13276, vicinity of Mole St. Nicolas, Haiti, 13-19 February 1929, which corresponds to $C$. pachysepalus. It would appear that $C$. pachysepalus and C. betulinus are found sympatrically in Haiti, as evidenced by the Leonard 13113 (US) collection, which is also from the vicinity of Mole St. Nicolas. Croton pachysepalus occupies an isolated position within a wellsupported clade of otherwise South American species (Figs. 3 \& 4), indicating that it may represent an independent dispersal event from South America to the Caribbean.

Croton pachysepalus is placed in $C$. subsect. Geiseleria, due to its placement in Clade A in Figs. 3 \& 4, and for its bifid styles. We have not been able to verify if the pistillate sepals are unequal or not.

62. Croton parodianus Croizat, Darwiniana 6: 452. 1944. TYPE: Brazil. Maranhão: island of São Luiz, Feb.-Mar. 1939, R. L. Fróes 11775 (holotype, A-47371!; isotypes, G-434656!, K-254441!, NY!, S-R-10555!, U-8010!).

Croton strobiliformis Secco, Revista Brasil. Bot. 32: 249. 2009. TYPE: Brazil. Pará: Tucuruí, margem direita do Rio Tocantins, BR-263, km 16, campina de solo arenoso, 30 Jan.1980, P. L. B Lisboa et al. 1286 (holotype, MG71358 !; isotypes, NY!, UB).

Distribution. Brazil (Amazonas, Maranhão, Pará, Mato Grosso, Rondônia, Roraima), Colombia (Guianía), Guyana, Venezuela (Amazonas).

Notes. Croton parodianus is placed in $C$. subsect. Geiseleria, due to its placement in Clade A in Fig. 3, in a polytomy with $C$. hostmannii and $C$. mollis, and for its unequal pistillate sepals and bifid styles. See Fig. 2B, C \& D for further morphological details.

63. Croton planaltoanus M. J. Silva \& Sodré, Syst. Bot. 39: 216. 2014. TYPE: Brazil. Goiás: Alto Paraíso de Goiás, cerca de $11 \mathrm{~km}$ da cidade em direção a Teresina de Goiás após o Morro do Japonês, $14^{\circ} 02^{\prime} 00^{\prime \prime} \mathrm{S}$, 47³1'40.3"W, 1540 m, 24 Nov. 2012, M. J. Silva \& J. P. Santos 4577 (holotype, UFG-60551, isotype, UB).

\section{Distribution. Brazil (Goiás).}

Notes. Croton planaltoanus is tentatively placed in $C$. subsect. Geiseleria, due to its slightly unequal pistillate sepals and bifid styles. It has not been sampled yet for molecular studies. 
64. Croton pluriglandulosus Carn.-Torres \& Riina, Ann. Missouri Bot. Gard. [this article, add volume and page \#]. TYPE: Brazil. Ceará: Guaraciaba do Norte, Chapada da Ibiapaba, 6 Apr. 1984, A. Fernandes \& S. Matos s.n. (holotype, HUEFS-106386!; isotype, EAC-12440!, HUEFS-111094!).

\section{Distribution. Brazil (Paraíba, Pernambuco, Piauí, Rio Grande do Norte).}

Notes. Croton pluriglandulosus is placed in C. subsect. Geiseleria, due to its position in Clade A of Figs. $3 \& 4$, and for its bifid styles. It is described as having equal pistillate sepals, which is at odds with most other members of the subsection.

65. Croton pycnadenius Müll. Arg., Fl. Bras. 11(2): 216. 1873. Oxydectes pycnadenia (Müll. Arg.) Kuntze, Revis. Gen. Pl. 2: 613. 1891. TYPE: Brazil. Tocantins: inter Funil et S. João, s. d., W. J. Burchell 8988 (lectotype, designated by Sodré et al. [2019a: 75], BR-8761354; isolectotypes, A-257984!, G-434631!, K-186103!).

Croton pardinus Müll. Arg., Fl. Bras. 11(2): 217. 1873. Oxydectes pardina (Müll. Arg.) Kuntze, Revis. Gen. P1. 2: 613. 1891. TYPE: Brazil. Mato Grosso do Sul: in campis siccis secus Rio Pardo, s. d., L. Riedel 467 (lectotype, designated by Sodré et al. [2019a: 75], LE-18220!; isolectotypes, G-434657! [photo F-24513!], LE-18221!).

Distribution. Brazil (Bahia, Goiás, Maranhão, Mato Grosso, Mato Grosso do Sul, Minas Gerais, Pará, Tocantins).

Notes. Croton pycnadenius is placed in C. subsect. Brasilienses due to equal pistillate sepals and bifid styles. Other characteristic compatible with the subsection are leaves with 5-9 main veins from the base and an overall very similar appearance to $C$. mucronifolius. It has not been sampled yet for molecular studies.

66. Croton ramillatus Croizat, J. Arnold Arbor. 26: 184. 1945. TYPE:

Mexico. Veracruz: Barranca de Panoya, Aug. 1919, C. A. Purpus 8450 (holotype, F!; isotype, UC-200854, US-109666!).

Croton gynopetalus Croizat, J. Arnold Arbor. 26:183. 1945, syn. nov. TYPE: Mexico. Oaxaca: San Gerónimo, Jul. 1914, C. A. Purpus 7159 (holotype, F-56033F!; isotypes, UC-175037, US-109575!).

Croton ramillatus var. insignilobus Croizat, J. Arnold Arbor. 26: 184. 1945. Type: Mexico: Chiapas, east of Hacienda Monserrate, Apr. 1926, C A. Purpus 10066 (holotype, UC; isotype, M-242048!).

Distribution. Mexico (Chiapas, Oaxaca, Veracruz).

Notes. Croton ramillatus is placed in C. subsect. Geiseleria, due to its placement in Clade A in Fig. 3, within the C. suavis complex, and for its unequal pistillate sepals and bifid styles. 
67. Croton ramosissimus Sodré \& M. J. Silva, Phytotaxa 329: 128. 2017. TYPE: Brazil. Goiás: Corumbá de Goiás, hillside opposite to the belvedere of Salto de Corumbá, to the left of BR-414 road, towards Cocalzinho, $15^{\circ} 50^{\prime} 53.2^{\prime \prime S} 48^{\circ} 46^{\prime} 07^{\prime \prime W}, 1050$ m, 10 Oct. 2016, R.C. Sodré, R. D. S. Nabarro \& F. Roa 2668 (holotype, UFG; isotypes, CEN, K, MICH, NY).

Distribution. Brazil (Distrito Federal, Goiás).

Notes. Croton ramosissimus is placed in C. subsect. Geiseleria due to its slightly unequal pistillate sepals and bifid styles. It has not been sampled yet for molecular studies.

68. Croton repens Schltdl., Linnaea 19: 237. 1847. Oxydectes repens (Schltdl.) Kuntze, Revis. Gen. P1. 2: 612. 1891. TYPE: Mexico. Veracruz: Hacienda de La Laguna, Jul. 1829, C. J. W. Schiede 40 (lectotype, designated by Webster [2001: 362[, HAL-98379!).

Croton rotundifolius Sessé \& Moc., Pl. Nov. Hisp. 166. 1887 [1890]. TYPE: Mexico. Sinaloa: in aridis Mazatlami montibus, s. d., M. Sessé y Lacasta \& J. M. Mociño 4132 (lectotype, designated by Nelson [1997: 395], MA602114 !); other original material, ibid. loc., M. Sessé y Lacasta \& J. M. Mociño 4130 (MA-602115!), s.n. (OXF!); illustration of 'Croton pubiflorum,' Torner Collection of Sessé and Mociño Biological Illustrations, Art Accession Number 6331.0910.

Distribution. Belize, El Salvador, Guatemala, Honduras, Mexico (Chiapas, Guerrero, Jalisco, México, Michoacán, Nayarit, Oaxaca, Sinaloa, Veracruz), Nicaragua.

Notes. Croton repens is placed in $C$. subsect. Ocalia due to its position in Clade D in Figs. 3 \& 4, and for its equal pistillate sepals and bifid styles.

69. Croton rhodotrichus Sodré \& M. J. Silva, Syst. Bot. 42: 338. 2017. TYPE: Brazil. Mato Grosso: Cuiabá, north side of the National Park Chapada dos Guimarães, on the road of Quilombo, ca. $10 \mathrm{~km}$ from the road MT-020, 15¹6'51"S, 5552'13"W, 680 m, 6 Mar. 2015, M. J. Silva, R. C. Sodré \& G. H. Silva 6518 (holotype, UFG-60353; isotype, UFMT43524).

\section{Distribution. Brazil (Mato Grosso).}

Notes. Croton rhodotrichus is placed in C. subsect. Geiseleria due to its strongly unequal pistillate sepals and bifid styles. It has not been sampled yet for molecular studies.

70. Croton sclerocalyx (Didr.) Müll. Arg., Linnaea 34: 134. 1865.

Podostachys sclerocalyx Didr., Vidensk. Meddel. Naturhist. Foren.

Kjøbenhavn 134. 1857. Croton sclerocalyx var. genuinus Müll. Arg., Linnaea 34: 134. 1865, nom. inval. Oxydectes sclerocalyx (Didr.) Kuntze, Revis. Gen. Pl. 2: 613. 1891. TYPE: Brazil. São Paulo: campis St. Carlos, 
1834, P. W. Lund s.n. (lectotype, designated by Sodré et al. [2019a: 79], C10011194!; isolectotypes, C-10011195!, G-312480!).

Croton mentiens (S. Moore) Pax, Nat. Pflanzenfam., Nachtr. 211. 1897.

Heterocroton mentiens S. Moore, Trans. Linn. Soc. London, Bot. 4: 461.

1895. TYPE: Brazil. Mato Grosso: Santa Cruz, 1891-1892, S. L. Moore

s.n. (holotype, BM-939427!).

Croton sclerocalyx var. hirsutissimus Müll. Arg., Linnaea 34: 134. 1865.

TYPE: Brazil. São Paulo: s. loc., s. d., L. Riedel 1626 (lectotype, designated by Sodré et al. [2019a: 79], LE-18222!; isolectotypes, GH277216!, LE-18223!, LE-18224!).

Croton rufidulus Baill., Adansonia 4: 347. 1864. Croton sclerocalyx var. rufidulus (Baill.) Müll. Arg., Prodr. 15: 662. 1866. TYPE: Brazil. Minas Gerais: s. loc., 1838-1839, P. Claussen 776 (lectotype, designated by Sodré et al. [2019a: 79], P-493385!; isolectotypes, P-493386!, G-434695).

Croton sclerocalyx f. luxurians Müll. Arg., Fl. Bras. 11(2): 226. 1873.TYPE:

Brazil. Minas Gerais: Lagoa Santa, s. d., J. E. B. Warming 1640 (holotype, G-00434697!).

Croton sclerocalyx var. intermedius Müll. Arg., Fl. Bras. 11(2): 226. 1873.

TYPE: Brazil. Minas Gerais: Caldas, 1869, A. F. Regnell III 1088

(lectotype, designated by Sodré et al. [2019a: 79], BR-8761170!; isolectotypes, A-257991!, US-109681!, US-997753!, US-1014155!).

Croton sclerocalyx var. hispidus Müll. Arg., Fl. Bras. 11(2): 226. 1873.TYPE:

Brazil. São Paulo: Junediahy, s. d., G. H. Langsdorff s.n. (lectotype, designated by Sodré et al. [2019a: 79], LE-18225!; isolectotype, G434694 !).

Distribution. Brazil (Distrito Federal, Goiás, Mato Grosso, Mato Grosso do Sul, Minas Gerais, São Paulo, Tocantins), Paraguay.

Notes. Croton sclerocalyx is placed in $C$. subsect. Podostachys due to its position in Clade C in Figs. 3 \& 4, close to C. hadrianii, C. grossedentatus, and $C$. sipaliwinensis. It also fits into this subsection with its numerous (6-7), equal pistillate sepals, multifid styles, and for having a gap between the pistillate and staminate portions.

71. Croton seccoi Sodré \& M. J. Silva, Phytotaxa 417(1): 80. 2019. TYPE:

Brazil. Piauí: Piracuruca, Parque Nacional das Sete Cidades, ( $5^{\text {a }}$ cidade), $4^{\circ} 6^{\prime} 12^{\prime \prime S}, 41^{\circ} 41^{\prime} 12 " \mathrm{~W}, 174$ m, 9 Feb. 2007, D. S. Carneiro-Torres, M. M. Silva-Castro \& D. Cardoso 836 (holotype, HUEFS-116972!; isotype, HUESB-4191).

Distribution. Brazil (Ceará, Maranhão, Pará, Piauí).

Notes. Croton seccoi is placed in $C$. subsect. Geiseleria due to its slightly unequal pistillate sepals and bifid styles. It has not been sampled yet for molecular studies.

72. Croton sincorensis Mart. ex Müll. Arg., Fl. Bras. 11(2): 86. 1873. Oxydectes sincorensis (Mart. ex Müll. Arg.) Kuntze, Revis. Gen. P1. 2: 613. 1891. TYPE: Brazil. Bahia: in silvis Catingas ad Sincorá, s. d. [Jan.- 
Mar. 1819], C. F. P. von Martius 1952 (lectotype, designated by Sodré et al. 2019a: 83], M-89119!; isolectotypes, G-434687!, M-89117!, M89118 !).

\section{Distribution. Brazil (Bahia, Espirito Santo, Minas Gerais, Pernambuco).}

Notes. Croton sincorensis is placed in C. subsect. Podostachys due to its position in Clade $\mathrm{C}$ in Figs. 3 \& 4, and for its equal pistillate sepals, multifid styles, and for having a gap between the pistillate and staminate portions.

73. Croton sipaliwinensis Lanj., Recueil Trav. Bot. Néerl. 36: 698. 1939 publ. 1940. TYPE: Suriname. Sipaliwini: sup. Kamp. XI, 10 Dec. 1935, H. E. Rombouts 357 (holotype, U-1899!; isotypes, K-254424!, US-109754!).

Croton sclerocalyx var. pubescens Müll. Arg., Linnaea 34: 134. 1865. TYPE: Guyana. s. loc., 1842-1843, M. R. Schomburgk 851 (holotype, B†; lectotype, designated by Sodré et al. [2019a: 83], P-634708!; isolectotype, G!, photo at F-24529!, K-186092!).

Croton macradenis Görts \& Punt, Bull. Mus. Natl. Hist. Nat. B Adansonia 5: 199. 1983, syn. nov. TYPE: French Guiana. Piste de St.-Elie, Sinnamary, 9 Jun. 1978, J. J. de Granville B-5470 (holotype, CAY-33539; isotypes, P77218!, P-77219!, U-1892!,US-432892!).

Distribution. Colombia (Casanare), Brazil (Amazonas, Mato Grosso, Maranhão, Pará, Rondônia), French Guiana, Guyana, Suriname, Venezuela (Amazonas, Bolívar).

Notes. When Croton macradenis was described, it was distinguished from $C$. sipaliwinensis mainly by its longer acropetiolar glands and somewhat larger leaves, but gland length varies almost continuously between the two, and leaf size is similarly variable. They share an unusually low number of stamens ( 5 or 6 ), interrupted thryrses, sylleptic branching, glabrous ovaries, bifid styles, and the coarsely dentate or biserrate leaves, so there is little reason to recognize them as separate species in this case. The species appears to be characteristic of white-sand savannas as well as the edges of granitic inselbergs.

Croton sipaliwinensis is placed in $C$. subsect. Podostachys due to its position in Clade $\mathrm{C}$ in Figs. 3 \& 4, its six equal pistillate sepals, bifid styles, and for having a gap between the pistillate and staminate portions.

74. Croton spica Baill., Adansonia 4: 362. 1864. Oxydectes spica (Baill.) Kuntze, Revis. Gen. Pl. 2: 613. 1891. TYPE: Brazil. Mato Grosso: s. loc., 1831-1833, C. Gaudichaud-Beaupré 249 (holotype, P-634647!, photo and fragment at F-0056198F!).

Croton tamberlikii Müll. Arg., F1. Bras. 11(2): 265. 1873. Oxydectes tamberlikii (Müll. Arg.) Kuntze, Revis. Gen. Pl. 2: 613. 1891. TYPE:

Brazil. Brazilia occidentali, s. d., Tamberlik s.n. (lectotype, designated by Sodré et al. [2019a: 87], W-51319!; isolectotypes, F-56204!, G-169991!, W-51320!). 
Croton chapadensis Müll. Arg., Fl. Bras. 11(2): 262. 1873. Oxydectes chapadensis (Müll. Arg.) Kuntze, Revis. Gen. Pl. 2: 613. 1891. TYPE: Brazil. Mato Grosso: Aldêa da Chapada, Sep. 1827, L. Riedel 1136 (lectotype, designated by Sodré et al. [2019a: 87], LE-3082!; isolectotypes, A-257904!, LE-3083!, P-5505085!).

Distribution. Brazil (Distrito Federal, Goiás, Mato Grosso, Mato Grosso do Sul, Tocantins).

Notes. Croton spica is placed in C. subsect. Geiseleria due to its unequal pistillate sepals and bifid styles. The ITS and $\operatorname{trn} L-F$ sequences obtained from Sodré \& Silva (2019b) also place it within Clade A (Figs. 2, 3), but should not be relied on as an indication of a more precise phylogenetic relationship.

75. Croton spiraeifolius Jablonski, Mem. New York Bot. Gard. 12(3): 164. 1965. TYPE: Venezuela. Amazonas: Cerro Yapacana, savanna 3, 1 Jan.1951, B. Maguire, R. S. Cowan \& J. J. Wurdack 30571 (holotype, NY688115!; isotypes, F-V0093314F!, S-S 07-12772, US-810683!).

Distribution. Brazil (Amazonas), Colombia (Amazonas, Caquetá, Vaupés), Venezuela (Amazonas).

Notes. Sodré et al. (2019a) treated this as a synonym of $C$. krukoffianus. The two species are recovered as closely related in the ITS phylogeny (Fig. 3), and they share the uncommon character among members of $C$. sect. Geiseleria of having multifid styles. They differ in that $C$. krukoffianus is much more densely pubescent with erect, golden-brownish, hirsute trichomes on the leaves and ovaries; also, the leaves are more coarsely dentate, over a longer part of the margin, with a more acute apex (vs. rounded and mucronate apex, entire margins except for uppermost portion of leaf, and relatively longer petioles in $C$. spiraeifolius). A number of specimens previously determined as belonging to $C$. spiraeifolius, such as Prance et al. 28847 (NY, from base of Serra do Aracá in Roraima state, Brazil), actually correspond to C. krukoffianus instead.

Croton spiraeifolius is placed in C. subsect. Podostachys due to its position in Clade $\mathrm{C}$ in Fig. 3, sister to C. krukoffianus, and for its 5-7 subequal pistillate sepals, highly multifid styles, and for having a gap between the pistillate and staminate portions.

76. Croton suavis Kunth, Bonpland \& Humboldt, Nov. Gen. Sp. 2: 76. 1817. TYPE: Venezuela. [Sucre]: near Cumaná, 19 July-17 Aug. 1799, A. J. A. Bonpland \& F. W. H. A. von Humboldt 1211 (holotype, P-Bonpl-669865!]; isotype, B-W-17852-00 0!, as Croton salicifolium, photo at F0BN005166)!.

Croton barbatus Kunth, Bonpland \& Humboldt, Nov. Gen. Sp. (quarto ed.) 2: 73. 1817. TYPE: Venezuela. [Sucre]: “Ad Cumaná", s. d. [1800], A. J. A. Bonpland \& F. W. H. A. von Humboldt s.n.. (holotype, P-Bonpl P00669858!, photo and fragment, A00047232!; isotype, P00129822!).

Croton guildingii Griseb., Fl. Brit. W.I. 38. 1859. Oxydectes guildingii 
(Griseb.) Kuntze, Revis. Gen. P1. 2: 611. 1891, syn. nov. TYPE: Saint Vincent and the Grenadines: St. Vincent, 1822, L. Guilding s.n. (holotype, K-253769 ex Herb. Hooker]!; isotype, G-DC-312863 [fragment ex Herb. Hooker], GOET-006459!).

Croton jardinii Müll. Arg., Linnaea 34: 119. 1865. Oxydectes jardinii (Müll. Arg.) Kuntze, Revis. Gen. Pl. 2: 612. 1891. TYPE: France. Martinique, s. d., D. E. S. Jardin 323 (holotype [ex Herb. Lenormand, not located; isotypes, A-47188 [fragment ex P]!, G-DC-312267!).

Croton wullschlaegelianus Müll. Arg., Flora 55: 10. 1872. TYPE: Grenada. s. loc., 1847, H. R. Wullschlägel 1004 (holotype, M-242106!).

Croton dussii Urb., Symb. Antill. 6: 15. 1909, nom. nov. for Croton subglaber Urb.(1902), nom. illeg., non C. subglaber (Kuntze) K. Schum. (1900). Croton guildingoides Radcl.-Sm. \& Govaerts, Kew Bull. 52: 187. 1997, nom. nov. pro Croton subglaber Urb., nom. illeg. TYPE: France. Martinique. prope Case-Pilote, St. Luce, s. d., A. Duss s.n. (holotype, B $\dagger$ ). Croton bondaensis Rusby, Descr. S. Am. Pl. 43. 1920. TYPE: Colombia. Magdalena: 6 mi N of Bonda, ca. 100 ft, 1 Nov. 1898, H. H. Smith 1467 (lectotype, designated here, NY-246518!; isolectotypes, CM-1254!, F56109F!, GH-47234!, MICH-1104793!, NY-246517 - from Masinga, 250 ft, in fruit, collected 17 July 1898!, P-623609!, PH-8863!, US-109511!).

Croton guaricensis Croizat, Mem. Soc. Cien. Nat. La Salle (Caracas) 10(26): 125. 1950. TYPE: Venezuela. Guárico: Distrito Infante, inmediaciones del Río Perro a unos $20 \mathrm{~km}$ al N de Espino, 2 Apr. 1950, L. Croizat s.n. (holotype, CAR \#830!; isotype, F-360238F!).

Croton novaespartae Croizat, Mem. Soc. Cien. Nat. La Salle (Caracas) 10(26): 124. 1950. TYPE: Venezuela. Nueva Esparta: Isla Margarita, planicie entre San Juan y La Asunción, Sep. 1948, L. Croizat s.n. (holotype, CAR \#838!; isotype, F!).

Croton larensis Steyerm., Fieldiana, Bot. 28(2): 314. 1952. TYPE: Venezuela. Lara: dry chaparral between Trujillo-Lara boundary and Carora, 305 m, 28 May 1944, J. A. Steyermark 58606 (holotype, F!; isotype, NY-262914!).

Distribution. Colombia (Atlántico, Magdalena), Lesser Antilles (Grenada, Martinique, St. Vincent), Trinidad, Venezuela (Lara, Falcón, Guárico, Nueva Esparta, Sucre, Zulia).

Notes. This is the first time that Croton suavis is being recognized as conspecific with $C$. guildingii and a long list of other taxa from the Caribbean and northern South America. Previously $C$. suavis had only been associated with one other collection besides the type, namely $R$. H. Schomburgk 944 by Klotzsch (1845: p. 48), but we re-examined that collection and not only determined that it actually corresponds to $C$. mollis instead, but also that it is the type collection of $C$. gardnerianus, a synonym of $C$. mollis. The locality given by Klotzsch for Schomburgk's collection was Barcellos on the Rio Negro [Amazonas state, Brazil], which is consistent with the distribution and habitat type of $C$. mollis.

The type of $C$. suavis is from Cumaná, in Estado Sucre on the eastern coast of Venezuela, where plants of this species can still be found today. Across the wide range of the species from Martinique to Trinidad and then along the South American coast and variously inland from eastern Venezuela 
to northern Colombia, there is considerable variation in the length of the acropetiolar glands as well as in leaf size, and there is also considerable similarity to the Central American C. jutiapensis, the Mexican C. ramillatus, and the Costa Rican C. ortholobus, a relationship that is supported by their proximity in the ITS phylogeny (Fig. 3).

In Kew's World Checklist of Selected Plant Families (WCSP 2020), Croton curassavicus Bold. is listed as a synonym of $C$. guildingii. We do not believe it is conspecific with what we treat here as $C$. suavis. Given the glands along the margins of the pistillate sepals and the broadly ovate, long-petiolate leaves with either no or else very small acropetiolar glands on the type specimens, $C$. curassavicus may be conspecific with $C$. hircinus Vent., a member of $C$. sect. Barhamia.

Croton suavis is placed in C. subsect. Geiseleria, due to its placement in Clade A in Figs. 3 \& 4, within the $C$. suavis complex, and for its unequal pistillate sepals and bifid styles.

77. Croton sublepidotus Müll. Arg., Fl. Bras. 11(2): 260. 1873. Oxydectes sublepidota (Müll. Arg.) Kuntze, Revis. Gen. P1. 2: 613. 1891. TYPE: Brazil. Piauí or Tocantins: s. loc., 1844, G. Gardner 3437 (holotype, BR8760715!; isotypes, G-434674!, OXF-91994!).

Distribution. Brazil (Tocantins).

Notes. Croton sublepidotus is placed in C. subsect. Brasilienses due to equal pistillate sepals and bifid styles. It also shares an overall similar appearance with $C$. mucronifolius and $C$. pycnadenius. It has not been sampled yet for molecular studies.

78. Croton subsuavis Croizat, J. Arnold Arbor. 21: 93. 1940. TYPE:

Colombia, s. d., J. C. B. Mutis 4438 (holotype, US-109767!; isotype, MA$663573 !)$.

Distribution. Colombia (Cundinamarca, Tolima).

Notes. Croton subsuavis is placed in C. subsect. Geiseleria, due to its unequal pistillate sepals and bifid styles. Besides the type collection, which lacked any collection locality, Croizat (1940) cited an additional paratype, Pennell 2858 (US), from Melgar, 900-1300 m, in Cundinamarca Department. This species is similar to $C$. jutiapensis from Central America, and thus forms part of the $C$. suavis complex. It has not been sampled yet for molecular studies.

79. Croton triangularis Müll. Arg., Linnaea 34: 128. 1865. Oxydectes triangularis (Müll. Arg.) Kuntze, Revis. Gen. P1. 2: 613. 1891. TYPE: Brazil. Bahia: inter Campos et Vittoria, Dec. 1836, F. Sellow 1242 (holotype, B-100127737!, photo at F-0BN005188!; isotype, A-47455!).

Distribution. Brazil (Bahia, Minas Gerais, Piauí). 
Notes. Croton triangularis is placed in C. subsect. Ocalia due to its position in Clade D in Figs. $3 \&$ 4, and for its equal pistillate sepals and tetrafid styles.

80. Croton trinitatis Millsp., Publ. Field Columbian Mus. Bot. Ser. 2: 57. 1900. TYPE: Guyana. s. loc., 1838, R. H. Schomburgk 241 (lectotype, designated by Van Ee \& Berry [2010: 82], BM-1124405!; isolectotype, G312806 !).

Croton miquelensis Ferguson, Rep. (Annual) Missouri Bot. Gard. 12: 49. 1901, nom. illeg. TYPE: U.S.A. Florida: Escambia Co., wharf at Pensacola, 20 Sep. 1886, A. H. Curtiss 15 (lectotype, designated by Van Ee \& Berry [2010: 82], GH-277262!).

Croton tragioides S. F. Blake, Contr. U. S. Natl. Herb. 24: 11. 1922. TYPE: Guatemala. Izabal: shores of Lake Izabal, 2 Jun. 1919, S. F. Blake 7854 (holotype, US-28448!).

Croton buchtienii Rusby, Mem. New York Bot. Gard. 7: 284. 1927. TYPE: Bolivia. Beni: distr. General José Ballivián Segurola, Reyes, 1000 ft, 26 Oct. 1921, H. H. Rusby 1332 (lectotype, designated by Van Ee \& Berry [2010: 82], NY-246520!; isolectotypes, GH-47237!, MICH-1104791!, NY-579361!, PH-8862!, US-1232343!, US-109512!).

Distribution. Belize, Bolivia, Brazil (widespread), Colombia, Costa Rica, Ecuador, El Salvador, French Guiana, Guatemala, Guyana, Honduras, Mexico, Nicaragua, Panama, Paraguay, Peru, Suriname, Trinidad \& Tobago, Venezuela.

Notes. Croton trinitatis was collected in Pensacola, Florida (Curtiss 15 ) in 1886 on ballast earth piles, and Curtis' specimen was used as the type of $C$. miquelensis Ferguson, but the species has not been recollected there again or anywhere else further north of Veracruz, Mexico.

We place $C$. trinitatis in $C$. subsect. Podostachys due to its position in Clade $\mathrm{C}$ in Fig. 3, sister to the rest of the subsection, and due to its equal pistillate sepals. It is one of the few species in this subsection with bifid styles. The inflorescences are so short in this species that it is difficult to determine if there is a gap between the pistillate and staminate portions, but that would be expected if its subsectional placement is correct. The trnL-F phylogeny (Fig. 4) recovers $C$. trinitatis in a polytomy with Clades $\mathrm{C}$ and $\mathrm{B}$, and as such it is not incompatible with it being assigned to $C$. subsect. Podostachys.

81. Croton uliginosus Sodré \& M. J. Silva, J. Torrey Bot. Club 145: 101. 2018. TYPE: Brazil. Goiás: Mineiros, Emas National Park, valley of the Avoador stream (tributary of the Jacúba River), ca. $16 \mathrm{~km}$ from the headquarters of the Mineiros Park, $1.5 \mathrm{~km}$ from the road, $18^{\circ} 0^{\prime} 34.4^{\prime \prime} \mathrm{S}$, 52॰56'14.6"W, 767 m, 15 Apr. 2016, R. C. Sodré et al. 2385 (holotype, UFG; isotypes, HJ, CGMS, K).

Distribution. Brazil (Goiás, Mato Grosso).

Notes. We tentatively place $C$. uliginosus in $C$. subsect. Brasilienses due to its strong resemblance to other species in that subsection such as $C$. 
junceus, both with narrow, subsessile leaves, sessile acropetiolar glands, and sharply ascending leaves that are appressed to the stem. The photographs and illustrations of C. uliginosus in Sodré \& Silva (2018b) and in Sodré et al. (2019a) show six pale, nearly equal pistillate sepals and clearly bifid styles, although they indicate that the styles can be more branched at times (up to ten stigmatic branches). All other members assigned here to $C$. subsect.

Brasilienses have five pistillate sepals. The white pistillate sepals and the presence in some specimens of a gap between the pistillate and staminate portions also suggests $C$. subsect. Podostachys, but we will need to await molecular study of specimens of this species to more firmly determine its proper placement in the section.

82. Croton varelae V. W. Steinm., Aliso 19: 182. 2001. TYPE: Mexico. Nayarit: Mpio. de Nayar, ca. $1 \mathrm{~km} \mathrm{~N}$ of Mesa del Nayar along trail to El Cangrejo and just before Arroyo El Cañaveral, $1300 \mathrm{~m}, 104^{\circ} 38^{\prime} 45^{\prime \prime} \mathrm{N}$, $22^{\circ} 13^{\prime} 45^{\prime \prime} \mathrm{W}, 14$ Oct. 1996, V. W. Steinmann 1063 (holotype, RSA-2676!; isolectotypes, ARIZ, BM-793076!, DAV!, FCME, IBUG-0162959, IEB164016, MEXU, MICH-1194787!, RSA-2677!, UCR-26, WISv0227300WIS!)

\section{Distribution. Mexico (Nayarit).}

Notes. There are two sheets at RSA labeled as the holotype, but RSA2676 is clearly the sheet illustrated in the protologue and noted there in the legend of Fig. 3 as the "holotype."

Croton varelae is placed in $C$. subsect. Geiseleria due it placement in Clade A in Figs. $3 \&$ 4, and because of its unequal pistillate sepals and bifid styles.

83. Croton verbenifolius Müll. Arg., Linnaea 334: 140. 1865. Oxydectes verbenifolia (Müll. Arg.) Kuntze, Rev. Gen. Pl. 613. 1891. TYPE: Brazil: in Brasilia Meridionali, s. d., F. Sellow 5379 (holotype, B†, photo at F0BN005193!). NEOTYPE, designated here, Brazil: Minas Gerais, in campo dicto serrado prope Caldas, s. d., A. F. Regnell III 1087 (BR13319274!; other sheets in this collecting series, A-257946! [on same sheet as Blanchet 1665, isotype of C. klotzschii var. bahiensis], BR13319199!, BR-13319205!, K-254393!, P-4831373!, UPS-V-943683!, UPS-V-943684!, US [sheet stamped 200471, not a barcode, ex UPS]!). Catarina).

Distribution. Brazil (Minas Gerais, Paraná, Rio Grande do Sul, Santa

Notes. In the protologue of Croton verbenifolius (Müller Argoviensis, 1865), only the Sello collection was cited, but this sheet was destroyed in Berlin during World War II. In his subsequent Flora Brasiliensis treatment (Müller Argoviensis 1873), Müller also cited the Regnell III 1087 collection from Minas Gerais, but without mentioning in which herbarium he had seen it. Of the eight sheets seen of this number, the only one actually annotated as this species by Müller himself is the one we selected above as the neotype at BR. It is known that Regnell would typically group together under the same 
collection number specimens that were collected on different dates and in different places, as evidenced by the UPS-V-943684 sheet, which was dated 24 January 1861, and the K-254393 sheet, which was dated 24 October 1864. Also, the P-04831373 sheet is much smaller-leaved than any of the other members of the collection series. Although we do recognize all these specimens as belonging to $C$. verbenifolius, they should not be taken as duplicates of the neotype sheet itself.

Smith \& Downs (1988) listed $C$. verbenifolius as a synonym of $C$. hirtus (which they recognized as C. glandulosus var. hirtus) in their treatment of Croton for the Flora of Santa Catarina state, but this was clearly incorrect. Their lead was apparently followed in the Catálogo del Cono Sur (Berry et al. 2008), where it was listed in synonymy under C. hirtus. Through an oversight, C. verbenifolius was not included in the revision of the Brazilian species of $C$. sect. Geiseleria by Sodré et al. (2019a). Our ITS molecular results (Fig. 3) show Ginzbarg 688 (UPCB), identified as C. verbenifolius, as being part of Clade D and sister to Ginzbarg 687 (SP), identified as C. glechomifolius, with strong support. As interpreted here, $C$. verbenifolius is an additional species that needs to be recognized and added to the Brazilian flora, although some of the determinations that we have found through online portals such as speciesLink will need to be reassessed.

Müller Argoviensis (1864) treated $C$. verbenifolius as a species with bifid styles and equal pistillate sepals, which is consistent with our placement of it within $C$. subsect. Ocalia and with a presumed close relationship with the similarly bifid-styled $C$. glechomifolius. They can be distinguished by the nearly orbicular leaves and trailing habit of C. glechomifolius, as opposed to the more triangular leaves and upright habit of $C$. verbenifolius.

84. Croton virgultosus Müll. Arg., Fl. Bras. 11(2): 104. 1873. Oxydectes virgultosa (Müll. Arg.) Kuntze, Revis. Gen. Pl. 2: 614. 1891. TYPE: Brazil. Bahia: ad margines silvarum siccarum et in pascuis prope Caxoeira, Feb. [1819], C. F. P. Martius 2202 (lectotype, designated by Sodré et al. [2019a: 95], M-89126!; isolectotypes, G-434719!, M-89124!, M-89125!, M-89127!, M-89128!).

Distribution. Brazil (Bahia, Ceará, Minas Gerais, Pernambuco, Piauí, and Rio Grande do Norte).

Notes. Croton virgultosus is tentatively placed in $C$. subsect. Geiseleria due to its unequal pistillate sepals and bifid styles. It has not been sampled yet for molecular studies.

\section{$\underline{\text { Excluded taxa }}$}

1. Croton tetradenius Baill., Adansonia 4: 343. 1864. TYPE: BRAZIL. Minas Gerais: s. loc., 1816-1821, A. F. C. P. Saint-Hilaire cat B1 1500 (lectotype, designated by Sodré et al. [2019a: 89], P-634739!, photo and fragment at F-56207F!; isolectotypes, P-634740!, P-634741!). 
Distribution. Brazil (Alagoas, Bahia, Ceará, Distrito Federal, Mato Grosso, Mato Grosso do Sul, Paraíba, Pernambuco, Rio Grande do Norte, Sergipe, Tocantins).

Notes. Croton tetradenius was treated by Van Ee et al. (2011) and by Sodré et al. (2019a) as belonging to $C$. sect. Geiseleria, due to the stipitate basilaminar glands and bifid styles. However, the molecular results (Figs. 3 \& 4) show multiple accessions of this species forming a well-supported clade that is nested among other outgroup sections of Croton and sister to $C$. sect. Adenophylli. It also possesses the same kind of smooth, trilobed columella apex that is characteristic of all members of $C$. sect. Adenophylli. It is noteworthy that $C$. pulegiodorus is sister to the other two accessions of $C$. tetradenius in the ITS phylogeny (Fig. 3). Since C. pulegiodorus has other morphological distinctions from $C$. tetradenius, it is recognized here as a separate species, rather than treated as a synonym of $C$. tetradenius, as Sodré et al. (2019a) did. Depending on the results of a more complete molecular analysis of these taxa along with a substantive number of species from $C$. sect. Adenophylli, they may either be included in $C$. sect. Adenophylli or else recognized as a distinct new section.

2. Croton pulegiodorus Baill., Adansonia 4: 361. 1864. Croton pulegioides Müll. Arg., Fl. Bras. 11(2): 259. 1873, nom illeg. Croton tristis Müll. Arg., Linnaea 34: 140. 1865, nom illeg. TYPE: Brazil. Bahia: Jacobina, St Thomé, Jun. 1844, J. S. Blanchet 3786 (lectotype, designated by Sodré et al. [2019a: 89], P-634607!; isolectotypes, BR-8761477!, G-312860!, G434633!, P-634608!, P-634609!).

Croton regelianus Müll. Arg., Fl. Bras. 11(2): 133. 1873. TYPE: Brazil. Minas Gerais: in umbrosis ad rivulum Cipó, Nov. 1824, L. Riedel 869 (lectotype, designated by Sodré et al. [2019a: 89], LE-18228!; isolectotypes, G-434626!, GH-257987!, K-186148!, LE-18226!, LE18227!).

Croton regelianus var. matosii Radcl.-Sm., Kew Bull. 49(1): 150. 1994.

TYPE: Brazil. Ceará: Chapada da Ibiapaba, Cocalzinho-Viçosa, 14 Jan. 1982, A. Fernandes \& F. Matos 11077 (holotype, K-186147!; isotype, EAC).

Distribution. Brazil (Bahia, Ceará, Goiás, Minas Gerais, Paraíba, Pernambuco, Piauí).

Notes. The molecular results also show that this species is outside of Croton sect. Geiseleria (see discussion above under C. tetradenius).Croton pulegiodorus can be differentiated from $C$. tetradenius by its two long-stipitate acropetiolar glands with an orbicular apex, whereas $C$. tetradenius has four or six shortly stipitate acropetiolar glands with a rounded apex.

3. Croton leptobotryus Müll. Arg., Fl. Bras. 11(2): 155. 1873. TYPE: Brazil. Minas Gerais: ad Lagoa Santa super rupes calcareas et in virgultis ad Sumidouro, 2 Dec. 1864, J. E. B. Warming 1628 (holotype, C-10011177!; isotypes, A-257981!, G-434560!). 
Distribution. Brazil (Goiás, Minas Gerais, São Paulo).

Notes. Although Croton leptobotryus was not sampled in the molecular analyses, it was synonymized by Sodré et al. (2019a) under $C$. tetradenius and is clearly closely related to it. Apparently, the two species can be differentiated by the number of petiolar glands (two in C. leptobotryus vs. four to six in $C$. tetradenius), the presence of marginal leaf glands (present in $C$. leptobotryus vs. absent in C. tetradenius), the morphology of the bracts (triangular in C. leptobotryus vs. linear to ovate in C. tetradenius), and the presence of reduced pistillate petals (present in $C$. leptobotryus vs. absent in $C$. tetradenius), but these differences should be reassessed as part of a broader analysis of the entire alliance, including C. pulegiodorus.

4. Croton santaritensis Huft, Ann. Missouri Bot. Gard. 75(3): 1123, f. 3. 1988. TYPE: Panama. Colón: Santa Rita Ridge Road, 21-26 km from Transisthmian Highway, 500-550 m, 9²5'N, 79³7'W, 4 Jul 1982, S. D. Knapp 5882 (holotype [in 2 sheets], MO-188835! and MO-188836!; isotypes, DAV!, F-56063F!, PMA!).

Distribution: Panama (Colón, Panamá).

Notes. See earlier discussion, where this species is now placed in $C$. sect. Cleodora.

5. Croton waltherioides Urb., Symb. Antill. 3: 292. 1902. TYPE: Haiti. prope Gonaives ad Ennery, 400 m, Apr. 1899, W. Buch 143 (holotype, B, destroyed; lectotype, designated here: GH-47256!).

\section{Distribution. Haiti.}

Notes. This poorly-known species was listed as belonging to $C$. sect. Geiseleria by Van Ee et al. (2011), but examination of the type and review of the protologue indicate that it likely does not belong here. It might belong in $C$. sect. Adenophylli instead. More material and study are needed to determine its proper affinities.

\section{Literature Cited}

Askew, S. D. and Wilcut, J.W., 2001. Tropic croton interference in cotton. Weed Sci. 49: 184-189.

Aymard, G. A. \& L. M. Campbell. 2008. Caraipa andina (Clusiaceae), a new species from the Venezuelan Andes, and its biogeographical implications. Rodriguésia 59: 393-398.

Baillon, H. 1858. Étude Générale du Groupe des Euphorbiacées. 684 pp. \& atlas of 52 plates. Victor Masson, Paris.

Bentham, G. 1854. On the North Brazilian Euphorbiaceae in the collections of Mr. Spruce. Hooker's J. Bot. Kew Gard. Misc. 6: 376-377.

Berry, P. E. \& C. Galdames. 2013. Croton cerroazulensis (Euphorbiaceae), a new species from Cerro Azul (Panama). Webbia 68: 17-19. 
Berry, P. E., A. L. Hipp, K. J. Wurdack, B. Van Ee \& R. Riina. 2005.

Molecular phylogenetics of the giant genus Croton and tribe Crotoneae (Euphorbiaceae sensu stricto) using ITS and trnL-trnF DNA sequence data. Amer. J. Bot. 92: 1520-1534.

Berry, P. E., M. Ferreira de Sales, R. Riina \& L. Barreto. 2007. New synonymy in Croton sect. Geiseleria (Euphorbiaceae) from the Caribbean and a new subspecies of Croton guildingii from Venezuela. Contr. Univ. Michigan Herb. 25: 171-177.

Berry, P. E., M. B. R. Caruzo, I. Cordeiro, H. J. Esser, F. J. Fernández-Casas, G. A. Levin, L. R. Lima, R. Riina \& K. J. Wurdack. 2008.

Euphorbiaceae, pp. 2010-2078 in F. O. Zuloaga, O. Morrone \& M. J. Belgrano (eds.), Catálogo de las Plantas Vasculares del Cono Sur, vol. 2. Missouri Botanical Garden, St. Louis, and Iboda, Argentina.

Burger, W. \& M. Huft. 1995. Flora costaricensis: Euphorbiaceae. Fieldiana Bot. 36: 1-169.

Carneiro-Torres, D. S. 2009. Diversidade de Croton L. (Euphorbiaceae) no bioma caatinga. Ph.D. thesis, Universidade Estadual de Feria de Santana, Bahia, Brazil. 296 pp.

Carneiro-Torres, D. S., I. Cordeiro, A. M. Giulietti, P. E. Berry \& R. Riina. 2011. Three new species of Croton (Euphorbiaceae s. s.) from the Brazilian Caatinga. Brittonia 63: 122-132.

Caruzo, M. B. R. \& I. Cordeiro. 2013. Taxonomic revision of Croton section Cleodora (Euphorbiaceae). Phytotaxa 121: 1-41.

Cordeiro, I., R. Secco, D. S. Carneiro-Torres, L. R. de Lima, M. B. R. Caruzo, P. E. Berry, R. Riina, O. L. M. Silva, M. J. da Silva \& R. C. Sodré. 2015. Croton in Lista de Espécies da Flora do Brasil. Jardim Botânico do Rio de Janeiro. Available at: $<$ http://floradobrasil.jbrj.gov.br/jabot/floradobrasil/FB17497>.

Croizat, L. 1940. Thirty-five new species of American Croton. J. Arnold Arbor. 21: 76-107.

Croizat, L. 1945. New or critical Euphorbiaceae from the Americas. J. Arnold Arbor. 26: 181-196.

Fawcett, W. \& A. B. Rendle. 1920. Flora of Jamaica, vol. IV. British Museum, Natural History, London.

Feio, A. C., R. Riina \& R. M. S. A Meira. 2016. Secretory structures in leaves and flowers of two Dragon's Blood Croton (Euphorbiaceae): New evidence and interpretations. Int. J. Pl. Sci. 177: 511-522.

Feio, A. C., M. I. Ore-Rengifo, P. E. Berry \& R. Riina, R. 2018a. Four new species of dragon's blood Croton (Euphorbiaceae) from South America. Syst. Bot. 43: 212-220.

Feio, A. C., R. M. Meira \& R. Riina. 2018b. Leaf anatomical features and their implications for the systematics of dragon's blood, Croton section Cyclostigma (Euphorbiaceae). Bot. J. Linn. Soc. 187: 614-632.

Gardner, G. 1846. Travels in the interior of Brazil principally through the northern provinces, and the gold and diamond districts, during the years 1836-1841. 562 pp. London, Reeve Brothers.

Gelman, A. \& D. B. Rubin 1992. Inference from Iterative Simulation Using Multiple Sequences. Statist. Sci. 7: 457-472.

Gouy, M., S. Guindon \& O. Gascuel. 2010. SeaView version 4 : a multiplatform graphical user interface for sequence alignment and 
phylogenetic tree building. Molec. Biol. Evol. 27(2): 221-224.

Govaerts, R., D. G. Frodin \& A. Radcliffe-Smith. 2000. World checklist and bibliography of Euphorbiaceae (and Pandaceae), 4 vols. Royal Botanic Gardens, Kew.

IUCN. 2012. IUCN Red List Categories and Criteria, Version 3.1. Second edition. Prepared by the IUCN Species Survival Commission. IUCN, Gland, Switzerland; Cambridge, United Kingdom.

Hind, D. J. N. 2012. Catalogue of Brazilian Plants. A transcription of George Gardner's manuscript. 123 pp. Archives collections of the Herbarium, Library, Art \& Archives, Royal Botanic Gardens, Kew.

Klotzsch, J. F. 1845. Euphorbiaceae. XIV. Contributions towards a Flora of South America - enumeration of plants collected by Mr. Schomburgk in British Guiana [overall article by G. Bentham]. London J. Bot. 2: 42-52.

Lott, E. J. 1987. Croton chamelensis (Euphorbiaceae), a new species from coastal Jalisco, Mexico. Brittonia 39: 302-305.

Martínez Gordillo, M., J. Jiménez Ramírez, R. Cruz Durán, E. Juárez Arriaga, R. García, A. Cervantes \& R. Mejía Hernández. 2002. Los géneros de la familia Euphorbiaceae en México. Anal. Inst. Biol., Univ. Nac. Autónoma de México, Serie Botánica 73(2): 155-281.

Masa-Iranzo, I., I. Sanmartín, M. B. R. Caruzo \& R. Riina. 2021. Skipping the Dry Diagonal: spatio-temporal evolution of Croton section Cleodora (Euphorbiaceae) in the Neotropics. Bot. J. Linn. Soc. Early view (online).

McVaugh, R. 1990. Botanical Results of the Sessé \& Mociño Expedition (1787-1803). VII. A Guide to Relevant Scientific Names of Plants. vii, 626 p. Hunt Institute for Botanical Documentation, Carnegie Mellon University. Pittsburgh.

Miller, M. A., W. Pfeiffer, W. \& T. Schwartz. 2010. Creating the CIPRES Science Gateway for inference of large phylogenetic trees. Pp. 1-8 in 2010 Gateway Computing Environments Workshop (GCE), New Orleans, LA. doi: 10.1109/GCE.2010.5676129.

Müller Argoviensis, J. 1865. Euphorbiaceae (excl. Euphorbieae). In: de Candolle, A.P. (Ed.) Prodromus systematis naturalis regni vegetabilis 15(2). Treuttel et Würtz, Paris, pp. 189-1261.

Müller Argoviensis, J. 1873. Euphorbiaceae. In Martius, C. F. P. von \& A. W. Eichler (eds.) .Flora Brasiliensis 11(2). 752 pp. Fleischer, München.

Nelson Sutherland, C. 1997. Material tipo de la colección de Sessé y Mociño en el Real Jardín Botánico de Madrid. Anales Jard. Bot. Madrid 55(2): 375-418.

Nylander, J. A. 2004. MrModeltest v2.0. Computer program distributed by the author, Department of Systematic Zoology, Uppsala University, Sweden. Available at website, http://www.ebc.uu.se/systzoo/staff/nylander. html.

QGIS Development Team. 2015. QGIS Geographic Information System. Open Source Geospatial Foundation. URL http://qgis.osgeo.org

Pax, F. 1903. Euphorbiaceae africanae. VI. Bot. Jahrb. Syst. 33: 276-291.

Preetha, S. S. \& M. S. Binojkumar. 2006. Croton hirtus L'Herit. (Euphorbiaceae), a fast naturalising exotic weed in Indian subcontinent. J. Econ. Tax. Bot. 30: 294-295. 
Radcliffe-Smith, A. 1978. Notes on African Euphorbiaceae: VIII. Kew Bull. 33: $233-242$.

Rafinesque, C. S. 1838. Sylva Telluriana. 184 pp., Philadelphia.

Rafinesque, C. S. 1840. Autikon Botanicon. 200 pp., Philadelphia.

Riina, R., P. E. Berry \& B. W. van Ee. 2009. Molecular phylogenetics of the dragon's blood Croton section Cyclostigma (Euphorbiaceae): a polyphyletic assemblage unraveled. Syst. Bot. 34: 360-374.

Riina, R., P. E. Berry, R. S. Secco, W. Meier \& M. B. R. Caruzo. 2018. Reassessment of Croton sect. Cleodora (Euphorbiaceae) points to the Amazon Basin as its main center of diversity. Ann. Missouri Bot. Gard. 103: 330-349.

Ronquist, F., M. Teslenko, P. van der Mark, D. L. Ayres, A. Darling, S. Höhna, B. Larget, L. Liu, M. A. Suchard \& J. P. Huelsenbeck. 2012. MrBayes 3.2: efficient Bayesian phylogenetic inference and model choice across a large model space. Syst. Biol. 61: 539-542.

Santos, R. F., R. Riina \& M. B. R. Caruzo. 2017. Diversity of arborescent lineages of Crotoneae (Euphorbiaceae) in the Brazilian Atlantic Rain Forest. Plant Syst. Evol. 303: 1467-1497.

Schomburgk, R. H. 1840. Journey from Esmeralda, on the Orinoco, to San Carlos and Moura on the Rio Negro, and thence by Fort San Joaquim to Demerara, in the Spring of 1839. J. Roy. Geog. Soc. London 10: 248-267.

Secco, R. S. 2008. Sinopse das espécies de Croton L. (Euphorbiaceae) na Amazônia brasileira: um ensaio taxonômico. Museu Paraense Emílio Goeldi, Belém, 169 pp.

Secco, R. S. 2009. A new species of Croton sect. Geiseleria (Euphorbiaceae) from Eastern Amazonian Brazil. Braz. J. Bot. 32: 249-252.

Secco, R. S., A. S. Rosario \& P. E. Berry. 2012. Croton campinarensis (Euphorbiaceae), a new species from eastern Amazonian Brazil. Phytotaxa 49: 1-5.

Silva, M. J. D., R. C. Sodré \& M. F. D. Sales. 2014. A new species of Croton L. (Euphorbiaceae s. s.) from the Brazilian Cerrado. Syst. Bot. 39: 216-221.

Smith, L. B. \& R. J. Downs. 1988. Euphorbiaceae, pp. 85-91, Fig. 30d-f in R. Reitz (ed.), Flora Ilustrada Catarinense. Itajaí, Brazil.

Sodré, R. C. \& M. J. da Silva. 2017. An overlooked new species of Croton section Geiseleria (Euphorbiaceae) from the Brazilian Cerrado, with a key to the species of this section occurring in the state of Goiás and in the Distrito Federal. Phytotaxa 329: 127-138.

Sodré, R. C. \& M. J da Silva. 2018a. Rediscovery of Croton hadrianii (Euphorbiaceae), a well distributed but long forgotten species in Brazilian Amazon. Phytotaxa 349(2): 141-151.

Sodré, R. C. \& M. J da Silva. 2018b. A new species of Croton L. (Euphorbiaceae) from the wet fields of Midwestern Brazil. J. Torrey Bot. Club 145: 100-107.

Sodré, R. C., P. E. Berry \& M. J da Silva. 2017. The tribe Crotoneae (Euphorbiaceae, Crotonoideae) in the Chapada dos Veadeiros, Goiás, Brazil. Phytotaxa 321(1): 1-59.

Sodré, R. C., M. Ferreira de Sales, P. E. Berry \& M. J da Silva. 2019a. Taxonomic synopsis of Croton section Geiseleria (Euphorbiaceae) in 
Brazil, including description of a new species. Phytotaxa 417(1): 1105.

Sodré, R. C., A. O. de Souza, A. A. Alonso \& M. J. da Silva. 2019b.

Molecular, morphological, and anatomical data support a new species of Croton sect. Geiseleria (Crotonoideae, Euphorbiaceae). Plant Syst. Evol. 305: 233-246. https://doi.org/10.1007/s00606-019-1566-z

Stearn, W. T. 1992. Botanical Latin. 4 ed. Timber Press, Portland.

Steinmann, V. W. 2001. New Euphorbiaceae from Mexico. Aliso 19(2): 181186.

Steinmann, V. W. 2002. Diversidad y Endemismo de la Familia Euphorbiaceae en México. Acta Bot. Mex. 61: 61-93.

Sun, Y., D. Z. Skinner, G. H. Liang \& S. H. Hulbert. 1994. Phylogenetic analysis of Sorghum and related taxa using internal transcribed spacers of nuclear ribosomal DNA. Theor. Appl. Genet. 89: 26-32. https:// doi.org/10.1007/BF00226978

Taberlet, P., L. Gielly, G. Pautou \& J. Bouvet. 1991. Universal primers for amplification of three non-coding regions of chloroplast DNA. P1. Molec. Biol. 17: 1105-1109.

Thiers, B. 2020 [continuously updated]. Index herbariorum: a global directory of public herbaria and associated staff. New York Botanical Garden's virtual herbarium. - Published at http://sweetgum.nybg.org/science/ih/ [accessed on 06 May 2020].

Urbatsch, L. E., B. G. Baldwin \& M. J. Donoghue. 2000. Phylogeny of the coneflowers and relatives (Heliantheae: Asteraceae) based on nuclear rDNA internal transcribed spacer (ITS) sequences and chloroplast DNA restriction site data. Syst. Bot. 25: 539-565.

Van Ee, B. \& P. E. Berry. 2010. Typification Notes for Croton (Euphorbiaceae). Harvard Papers Bot. 15(1): 73-84.

Van Ee, B. W. \& P. E. Berry. 2016. Croton. In G. A. Levin \& L. Gillespie [eds.], Flora of North America: Volume 12: Magnoliophyta: Vitaceae to Garryaceae.

Van Ee, B. W., P. E. Berry, R. Riina \& J. E. Gutiérrez Amaro. 2008. Molecular phylogenetics and biogeography of the Caribbean-centered Croton subgenus Moacroton (Euphorbiaceae s. s.). Bot. Rev. 74: 132165.

Van Ee, B., P. E. Berry \& S. Ginzbarg. 2009. An assessment of the varieties of Croton glandulosus (Euphorbiaceae) in the United States. Harvard Papers Bot. 14(1): 45-59.

Van Ee, B. W., R. Riina \& P. E. Berry. 2011. A revised infrageneric classification and molecular phylogeny of New World Croton (Euphorbiaceae). Taxon 60: 791-823.

Villaseñor, J. L. 2016. Checklist of the native vascular plants of Mexico. Rev. Mex. Biodiv. 87: 559-902.

Vitarelli, N. C., R. Riina, M. B. R. Caruzo, I. Cordeiro, J. Fuertes-Aguilar \& R. M. S. A. Meira. 2015. Foliar secretory structures in Crotoneae (Euphorbiaceae): Diversity, anatomy, and evolutionary significance. Amer. J. Bot. 102: 833-847.

Wang, Q., Deng, Y., Wang, Z., \& Huang, M. 2012. Croton hirtus (Euphorbiaceae), a new alien species from Hainan, China. J. Trop. Subtrop. Bot. 20: 58-62. 
WCSP. 2020. World Checklist of Selected Plant Families. Facilitated by the Royal Botanic Gardens, Kew. Published on the Internet; http://wcsp.science.kew.org/ Retrieved 17 November 2020.

Webster, G. L. 2001. Synopsis of Croton and Phyllanthus (Euphorbiaceae) in western Mexico. Contr. Univ. Michigan Herb. 23: 353-388.

Webster, G. L. \& M. J. Huft. 1988. Revised synopsis of Panamanian Euphorbiaceae. Ann. Missouri Bot. Gard. 75: 1087-1144.

Webster, G. L., M. J. Del-Arco-Aguilar \& B. A. Smith. 1996. Systematic distribution of foliar trichome types in Croton (Euphorbiaceae). Bot. J. Linn. Soc. 121: 41-57.

Wheeler, L. C. 1975. Euphorbiaceous genera lectotypified. Taxon 24: 534538.

White, T. J., T. Bruns, S. Lee \& J. W. Taylor. 1990. Amplification and direct sequencing of fungal ribosomal RNA genes for phylogenetics. In M. A. Innis, D. H. Gelfand, J. J. Sninsky, and T. J. White [eds.], PCR protocols: a guide to methods and applications, 315-322. Academic Press, New York, New York, USA.

\section{Figure Legends}

Figure 1: Schematic representation of species richness and endemism of Croton sect. Geiseleria by country across its native geographic range. Outer circle sizes are proportional to the overall number of species (dark gray) and the number of endemic species (light gray). The total numbers of species are also listed for the individual countries or areas, with the number of species endemic to each area in parentheses.

Figure 2: - A. Acropetiolar nectaries of Croton pluriglandulosus. - B. Pistillate flowers of Croton parodianus, showing the bifid styles. - C, D. Staminate portion of an inflorescence of $C$. parodianus showing persistent bracts remaining after the flowers have dehisced. - E. Detail of a cupular receptacle of the pistillate calyx remaining after capsule dehiscence, from $C$. glandulosus var. floridanus; note also the irregularly fimbriate apex of the columella. - F. Detail of a cupular receptacle of the pistillate calyx remaining after capsule dehiscence, from C. carandaitensis. A by Daniela CarneiroTorres; B, C \& D by Günter Gerlach, taken at Laja Caranacoa, near Puerto Inírida, Dept. Guainía, Colombia $\left(03^{\circ} 45^{\prime} \mathrm{N}, 67^{\circ} 59^{\prime} \mathrm{W}\right)$. E by P. E. Berry, from Berry 8059 (MICH); F from Rojas 7189 (A-47262).

Figure 3: Majority-rule consensus of the post-burn-in trees from the Bayesian analysis of ITS. The clade corresponding to Croton sect. Geiseleria is labeled, as are the subsections and the sectional assignments of the species from other sections. Branches with 95\% Bayesian Posterior Probability or greater support are thicker. When multiple accessions of a given species are included, they are distinguished by including the collector number in the label. The broad geographical sources of the accessions are colored according to the map insert on the left.

Figure 4: Majority-rule consensus of the post-burn-in trees from the Bayesian 
analysis of $\operatorname{trn} L-F$. The clade corresponding to Croton sect. Geiseleria is labeled, as are the subsections and the sectional assignments of the species from other sections. Branches with 95\% Bayesian Posterior Probability or greater support are thicker. When multiple accessions of a given species are included, they are distinguished by including the collector number in the label.

Figure 5. Croton almadinensis Caruzo \& Riina. - A. Image of isotype at NY. -B. View of a node showing a green, linear stipule, ferrugineous stellate trichomes on the petiole, and two long-stipitate acropetiolar glands; note also the long porrect ray of some of the trichomes on the adaxial leaf surface. - $\mathrm{C}$. Detail of leaf margin showing two narrowly cylindrical marginal glands and a mixture of stellate and stellate-porrect trichomes on the adaxial leaf surface.

-D. A branching node showing linear stipules and ferrugineous trichomes on the young vertical stem. - E. Pistillate flower at anthesis, showing short pedicel, bifid styles, and narrow, unequal sepals. - F. Beginning of capsule dehiscence, showing persistent sepals and short pedicel. - G. Mature capsule stage shown from below, with persistent, wells separated sepals; note the marginal glands on the adjacent leaf. - $\mathrm{H}$. Distal portion of an inflorescence, showing staminate cymules (most flowers dehisced, but one bud remaining towards the bottom). A from Fiaschi et al. 2922 (NY); B and G from Fiaschi et al 372 (MICH); C and D from Almeida \& Santos 41 (DAV); E, F, and H from Fiaschi et al. 2771 (MICH).

Figure 6. Distribution map of the seven new species of Croton sect. Geiseleria in South America.

Figure 7. Croton amaraliae Riina \& P. E. Berry. - A. Image of isotype at NY. -B. Base of a leaf blade, abaxial side, showing a pair of stipitate acropetiolar nectary glands. - C. Detail of crenate leaf margin on the abaxial side of a leaf, with stipitate glands in most of the sinuses. - D. Stipitate stellate trichomes along the margin and abaxial side of a leaf. - E. Stem with a leaf petiole, axillary bud, and dark brown filiform stipule. - F. Distal, staminate portion of an inflorescence; note the persistent, awl-shaped stipules. - G. Basal portion of an inflorescence showing young capsules. All figures from Amaral et al. $872(\mathrm{NY})$.

Figure 8. Croton cuadrosii P. E. Berry. - A. Image of holotype at MO. -B. Young inflorescence (in bud) showing large basal pistillate bracts and smaller distal staminate bracts. - C. Detail of large, foliaceous stipule in upper center of image. -D. Pair of acropetiolar nectary glands. - E. Trumpet-shaped marginal leaf glands and a colleter on the tooth tip between the two largest glands. -F. Detail of abaxial leaf surface showing the scattered rosulatestellate trichomes. - G. Dissected pistillate flower showing subequal sepals with nectary disks at base and stellate ovary with styles. All figures from Cuadros 2643 (MO).

Figure 9. Croton curculiospermus Riina. - A. Image of isotype at K. -B. Seeds in dorsal and ventral views. - C. Close-up of seed apices, showing the dark 'curculionoid snout' and beak-like yellowish caruncle. - D. Base of leaf, adaxial surface, showing one of the pair of shortly stipitate acropetiolar 
nectary glands and dense stellate-porrect trichomes. A and D from Wood \& Mendoza 19161 (K), B and C from Wood \& Mendoza 19161 (USZ).

Figure 10. Croton huamaliensis Riina. -A. Image of holotype at MICH. - B. Inflorescence; note the persistent acicular bracts. - C. Inflorescence with open pistillate flowers and staminate flowers just beginning to open; note the acropetiolar nectary glands in lower right side. - D. Pistillate flower, closeup, showing the long porrect rays of trichomes, especially on the ovary. - E. Young shoot tip showing dense indumentum and filiform stipules. - F. Stipitate acropetiolar nectary glands and base of leaf on the abaxial side. A from Schunke-Vigo 1098 (MICH); B, C, and D from Schunke-Vigo 1098 (DAV), E and F from Schunke-Vigo 1098 (NY).

Figure 11. Croton kallunkiae Riina \& Caruzo. -A. Image of isotype at NY.

-B. Base of leaf, abaxial side, showing two short acropetiolar nectary glands.

-C. Leaf margin, abaxial side of leaf, showing a marginal gland in the sinus; note also the long porrect ray of the stellate trichomes. - D. Young shoot tip, showing the linear stipules. -E. Basal, pistillate portion of an inflorescence (the distal staminate portion has broken off), showing the densely pubescent, spathulate sepals. - F. Staminate cymules on the distal portion of an inflorescence. A, B, D, and F from Kallunki \& Pirani 332 (NY), C and E from Mori et al. 10722 (DAV).

Figure 12. Croton pluriglandulosus Carn.-Torres \& Riina. -A. Flowering branch. - B. Detail of crenate leaf margin. - C. Trichomes on adaxial leaf surface. - D. Denser trichomes on abaxial leaf surface. - E. A stellate-porrect trichome typical of vegetative growth. -F. Stellate-porrect trichome with a more elongate central porrect arm, found mainly on the capsules. - G. Base of leaf showing the multiple acropetiolar nectary glands. $-\mathrm{H}$. Staminate flower. -I. Pistillate flower. - J. Developing capsule. -K. Seed (ventral view). Drawn from Fernandes \& Matos s.n. (HUEFS-106386). 


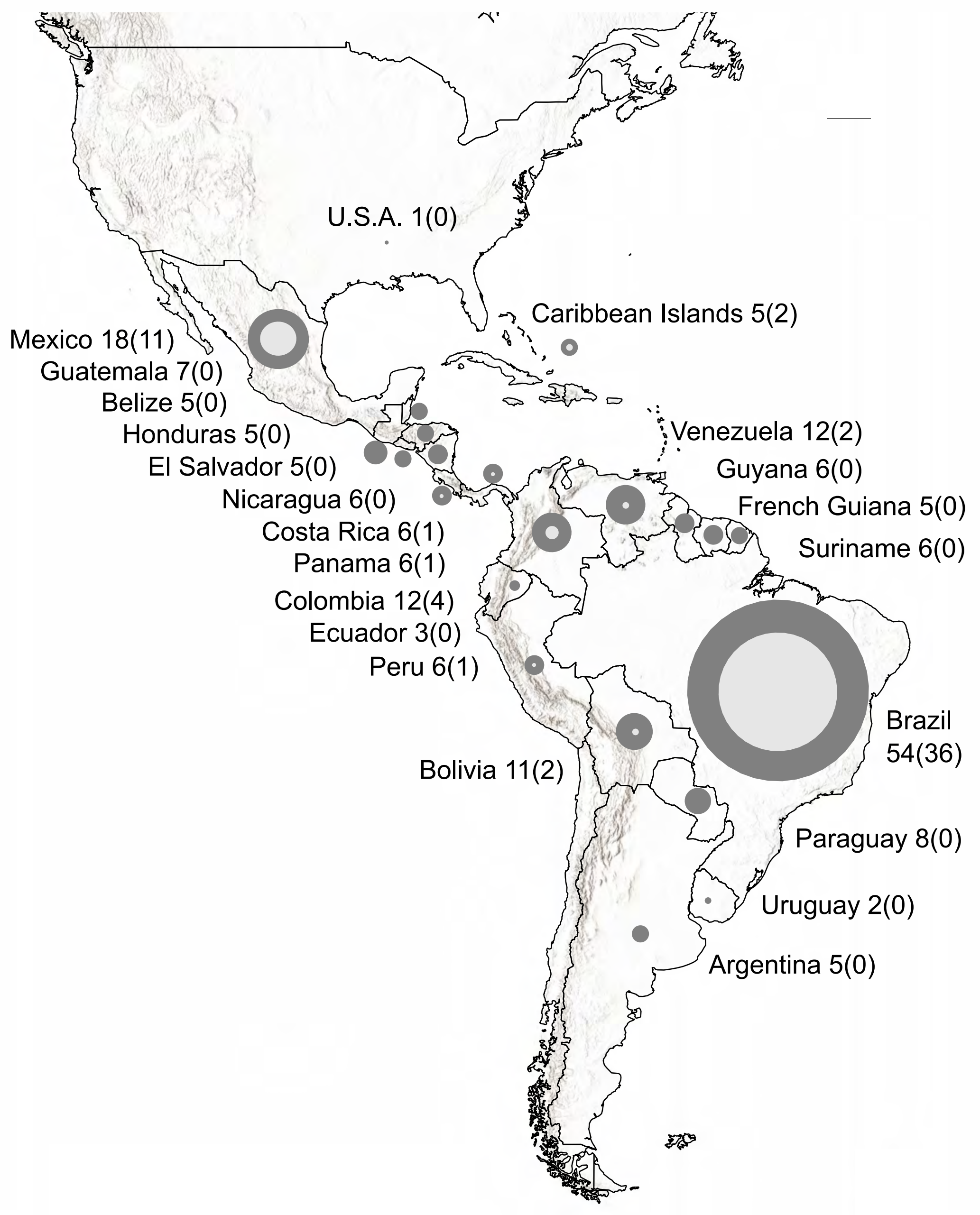




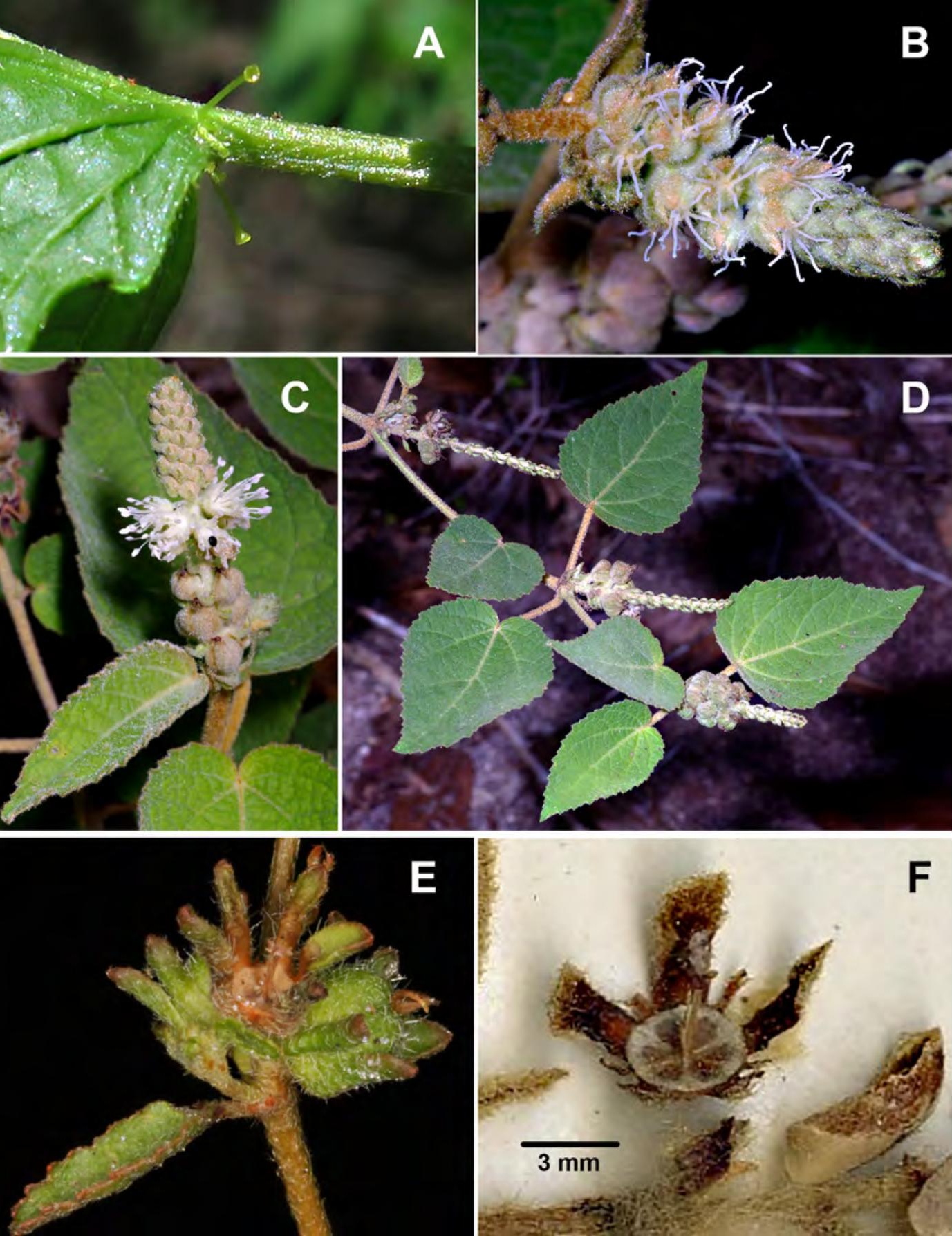









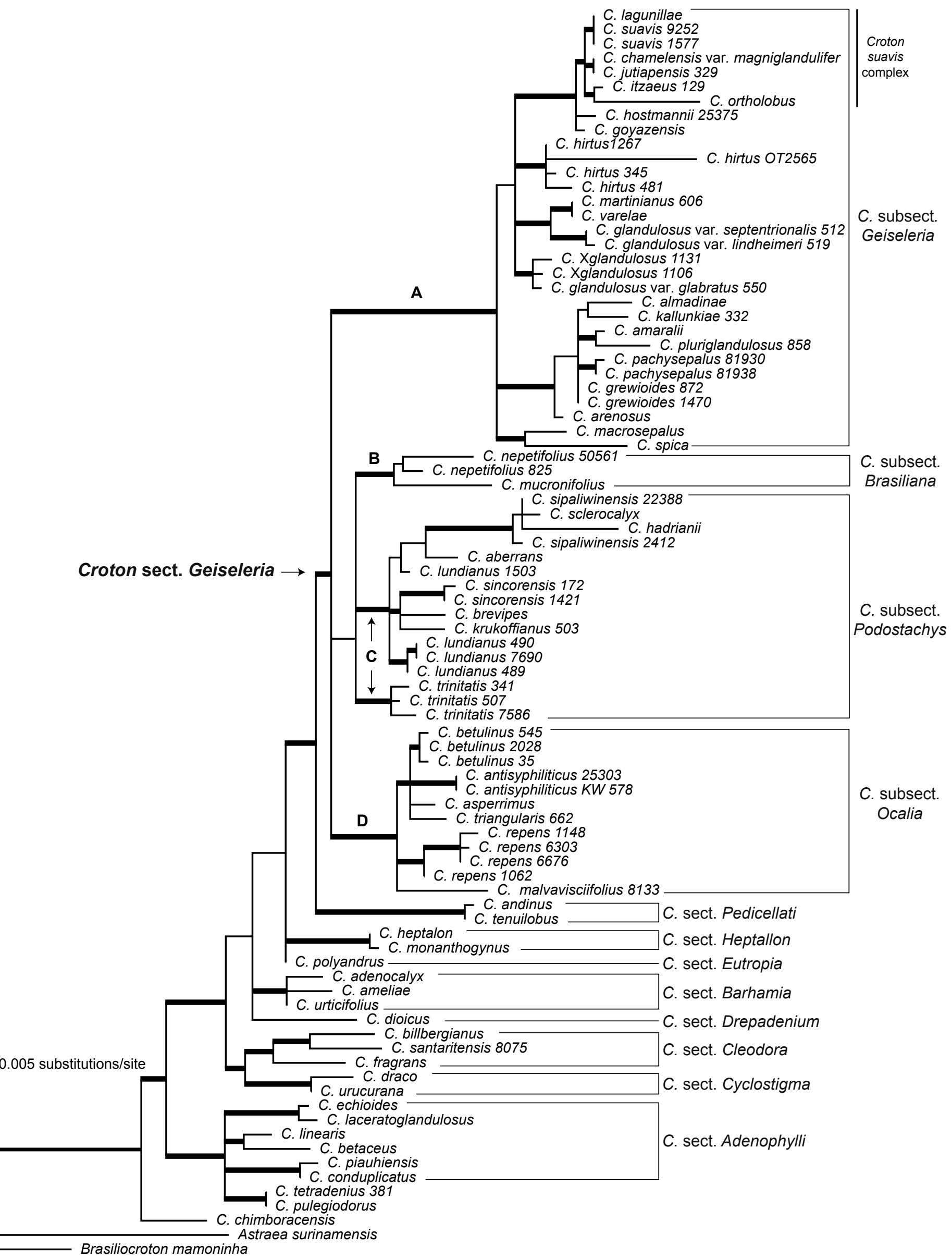




\section{$\ldots$}

\section{A}

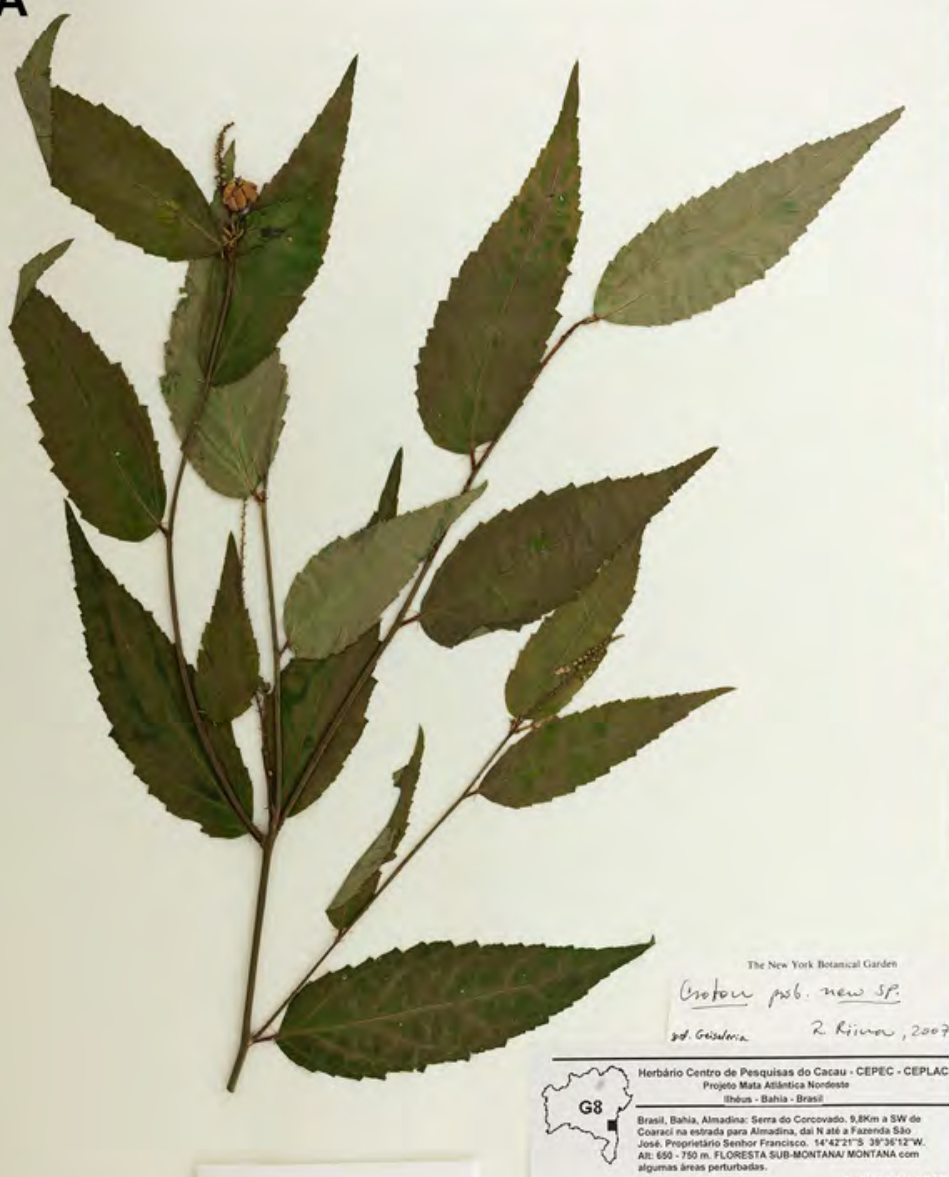

Croton sp

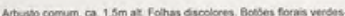

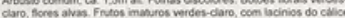
verdest escuro.
B

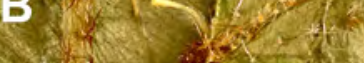

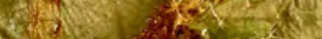

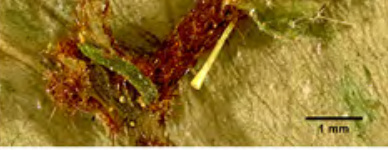

C






$\ldots \ldots$ мсн 8

A

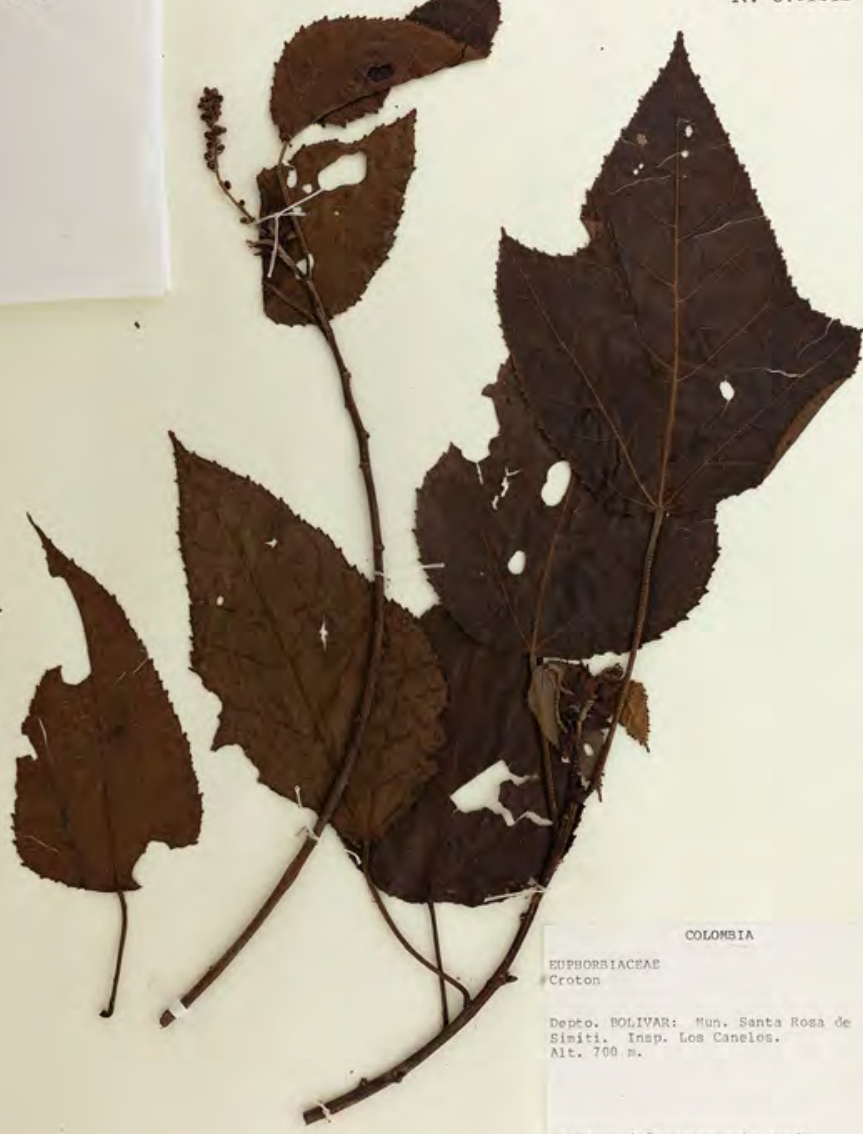

croton cuadrosi; P.E. Bery HOLOTYPE

On P. Berry Mich
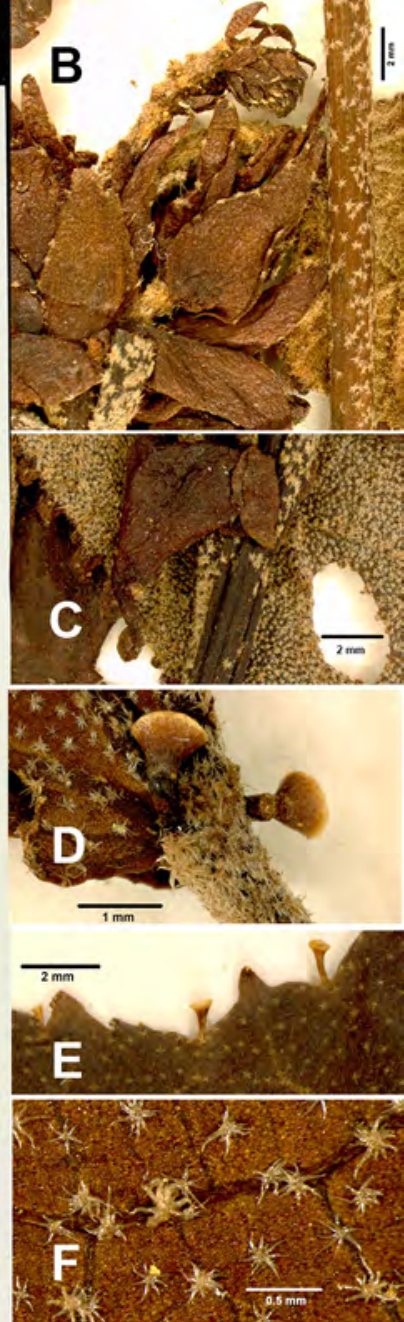

Arbusto, inf ructescencla verde.




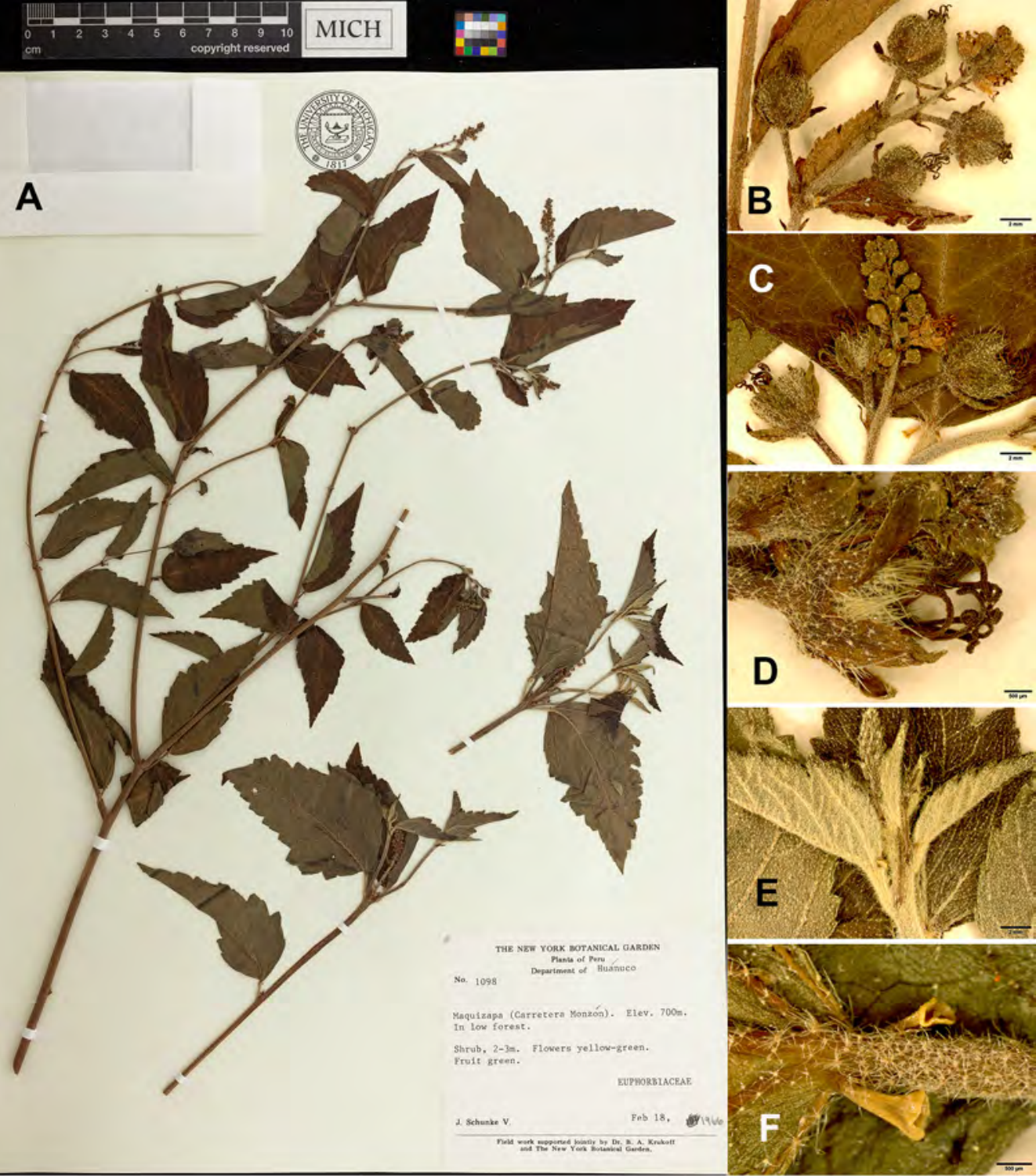







A
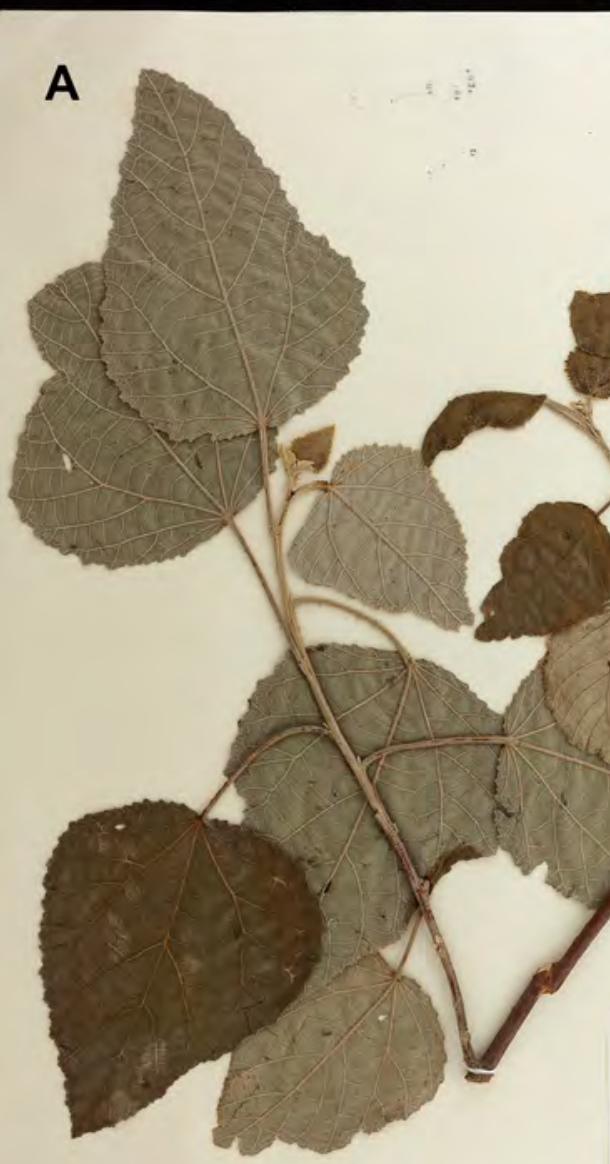

\section{$\mathrm{MICH}$}

THE NEW YORK BOTANICAL CARDEN

No. 332

EUPHORBIACEAE

croton of draconodes Mull Ang

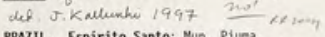
BRozIL. Espirito Santo: Mun. Piuma, roadside at base of Morro do Agá, ca. $5 \mathrm{~km} \mathrm{~S}$ of Piuna on Rod. ES-60. 20.52's, 40.46' Very disturbed patch of restinga forest.

Tree $5 \mathrm{~m}$. Perianth and stamens white. Margin of forest.

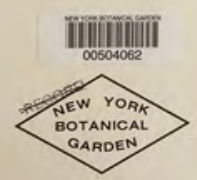

C

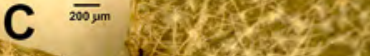

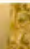

Q19.8



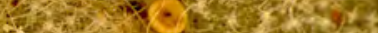

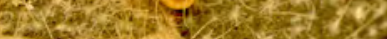

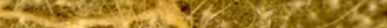

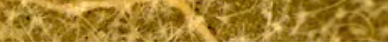
D) $\overline{1 \mathrm{~mm}}$

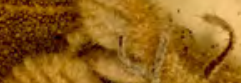

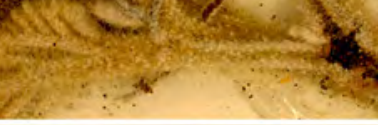


E

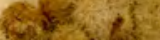
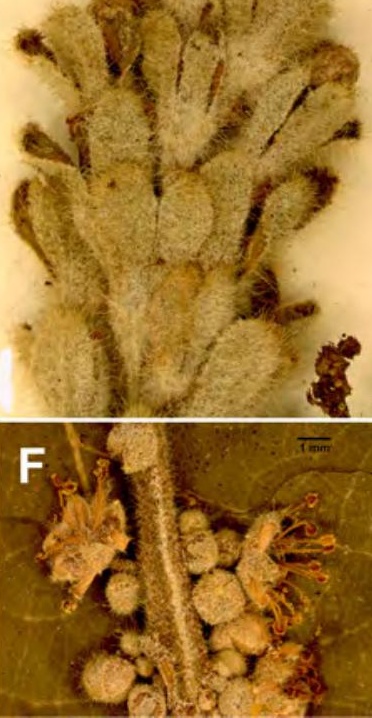


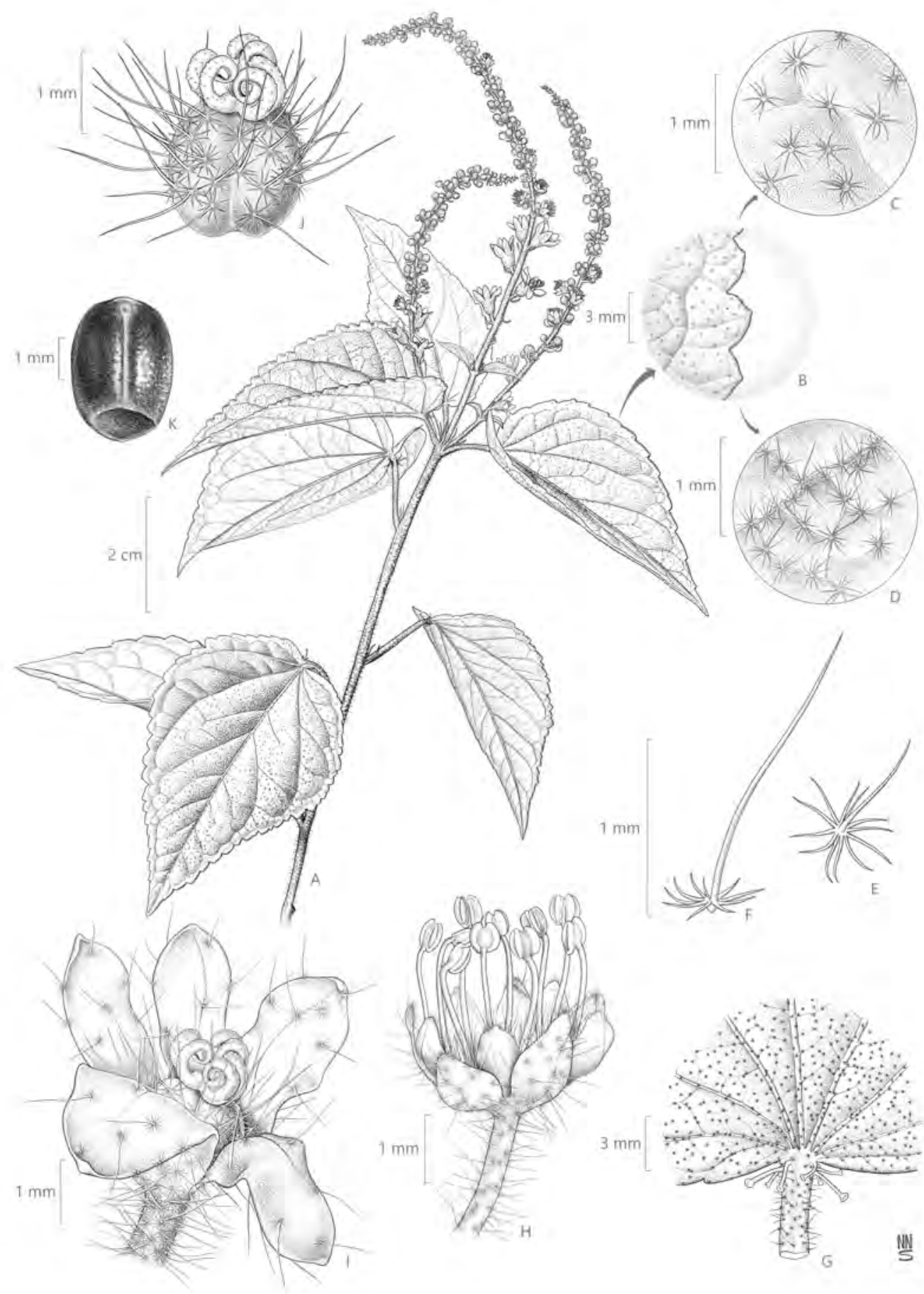

